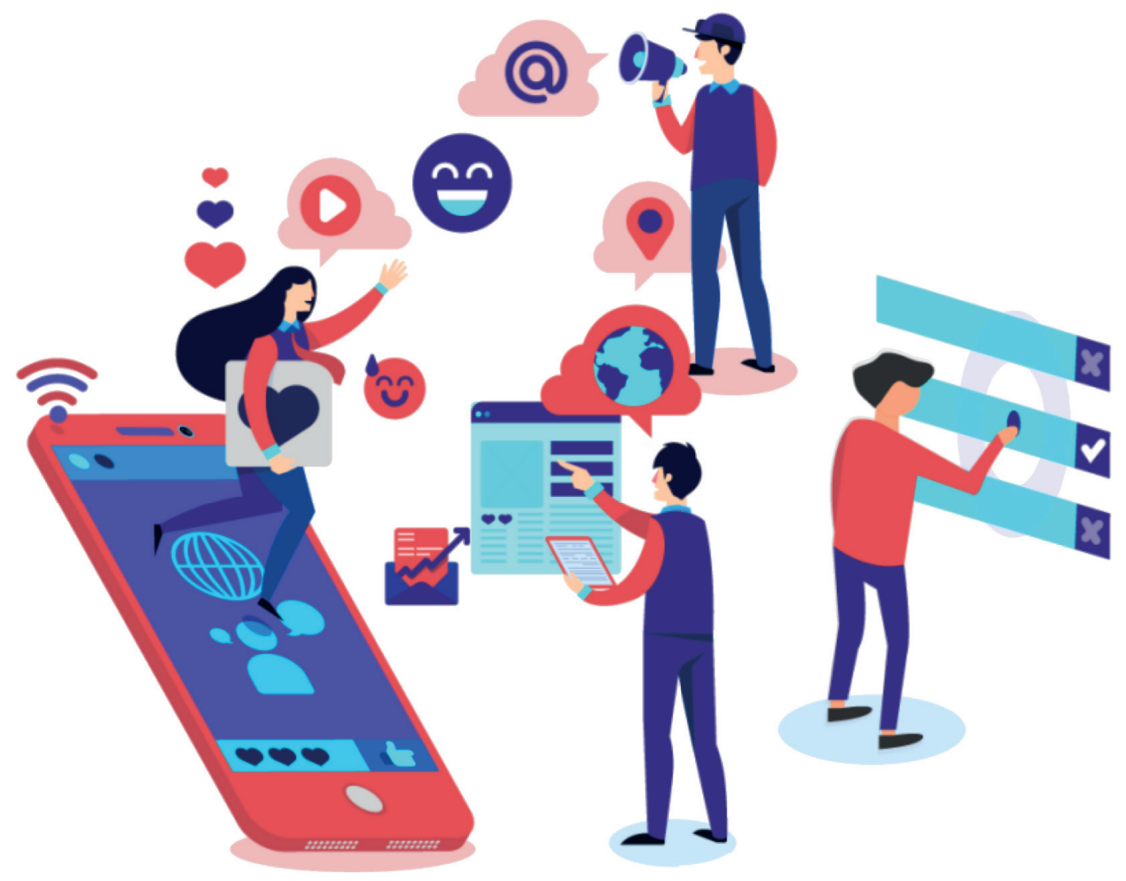

Aktuální problémy mediální výchovy a mediální gramotnost žáků 2. stupně ZŠ

Klára Mikulcová, Kamil Kopecký 
Univerzita Palackého v Olomouci

Pedagogická fakulta

Katedra českého jazyka a literatury

\section{Aktuální problémy mediální výchovy a mediální gramotnost žáků 2. stupně ZŠ}

Klára Mikulcová

Kamil Kopecký 


\section{Recenzenti}

RNDr. Pavel Pešat, Ph.D.

Mgr. Dominik Voráč

Publikace byla realizována v rámci grantového projektu IGA (IGA_PdF_2020_035).

Neoprávněné užití tohoto díla je porušením autorských práv a může zakládat občanskoprávní, správněprávní, popř. trestněprávní odpovědnost.

\section{1. vydání}

(c) Klára Mikulcová, Kamil Kopecký, 2020

(C) Univerzita Palackého v Olomouci, 2020

ISBN 978-80-244-5900-4 (print)

ISBN 978-80-244-5901-1 (online: PDF) 


\section{Obsah}

Úvod do problematiky

$\begin{array}{lll}1 & \text { Teoretické ukotvení základních pojmů } & 7\end{array}$

$\begin{array}{lll}1.1 & \text { Média } & 7\end{array}$

1.2 Mediální výchova 9

$\begin{array}{ll}1.3 \text { Mediální gramotnost } & 10\end{array}$

1.4 Sociální sítě 11

1.5 Vybrané aktuální problémy mediální výchovy 12

$\begin{array}{ll}\text { 1.5.1 Dezinformace } & 13\end{array}$

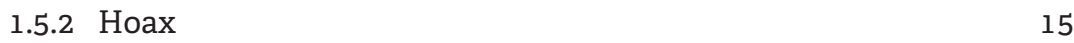

1.5.3 Falešné internetové uživatelské účty 16

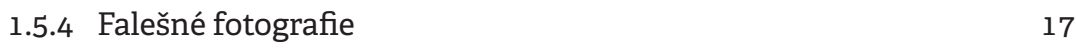

$\begin{array}{ll}\text { 1.5.5 Mediální stereotypy } & 19\end{array}$

1.5.6 Reklama 20

1.5.7 Hating 23

2 Metodologie výzkumu 25

2.1 Výzkumné cíle a problémy $\quad 25$

$\begin{array}{ll}2.2 \text { Výzkumný vzorek } & 27\end{array}$

2.3 Výzkumný nástroj $\quad 29$

2.4 Časový harmonogram výzkumu 31

2.5 Data a jejich zpracování 31

2.5.1 Dotazník-1. část 31

2.5.2 Dotazník-2. část 32

3 Výsledky výzkumu

3.1 Dotazník-1. část 33

3.1.1 Zdroj informací, který žáci používají nejčastěji 34

3.1.2 Ověřování pravdivosti informací a fotografií na internetu 35

3.1.3 Ověřování pravdivosti profilů uživatelů na sociálních sítích $\quad 40$

3.1.4 Vliv influencerů na žáky $\quad 44$

3.1.5 Nenávistné př́spěvky na sociálních sítích 50

3.2 Dotazník-2. část 56 
$4 \quad$ Shrnutí výsledků

5 Diskuze

102

6 Závěr 104

Seznam použitých zdrojů 106

O autorech 111

Seznam grafů 113

Seznam tabulek 115

Seznam obrázků 116 Anotace 117

Summary 118

Rejstř́k 119 


\section{Úvod do problematiky}

Předkládaná monografie prezentuje výsledky výzkumu vybraných aktuálních problémů mediální výchovy u žáků 2. stupně ZŠ a vztah těchto žáků k médiím s důrazem na sociální sítě. Zaměřuje se konkrétně na tyto faktory:

- jaký zdroj informací používají žáci nejčastěji,

- zda si žáci ověřují pravdivost informací, fotografií a profilů uživatelů na sociálních sítích a podle jakých kritérií se rozhodují,

- zda jsou schopni na základě názorných př́kladů rozeznat dezinformace, hoaxy, falešné internetové profily a fotografie, product placement, sexismus v reklamách, klamavou reklamu, mediální stereotypy, hating a veřejnoprávní média,

- zda žáky ovlivňují influenceři, které na sociálních sítích sledují (influenceři jsou lidé, kteří mají na sociálních sítích určitý vliv a větší množství uživatelů, kteří je sledují, tzv. followerů),

- zda žáci píšou nenávistné příspěvky na internet,

- zda ovlivňuje četba nenávistných příspěvků vztah žáků k dané skupině (etnické, náboženské apod.),

- zda žáci někdy byli obětí nenávistných příspěvků na internetu.

Výzkum byl realizován v rámci grantového projektu IGA (IGA_ PdF_2020_035) a zároveň je součástí disertační práce hlavní řešitelky projektu.

V první kapitole monografie se zabýváme teoretickým ukotvením základních pojmů, které s realizovaným výzkumem úzce souvisí. Jedná se o pojmy jako média, mediální výchova, mediální gramotnost a sociální sítě. Ve stručnosti si také nastíníme teoretický základ vybraných aktuálních 
problémů mediální výchovy - vysvětlíme si, co to jsou dezinformace, hoax, falešná fotografie, falešný účet na sociálních sítích, mediální stereotyp, reklama a hating.

Jádro monografie tvoří druhá, třetí a čtvrtá kapitola, která shrnuje metodologická východiska a následně výsledky výzkumu. Popíšeme zde výzkumné cíle a problémy, podobu výzkumného vzorku, zvolenou výzkumnou metodu, časový harmonogram a způsob zpracování dat. Výsledky výzkumu budou pečlivě zpracovány pomocí tabulek či grafů, analyzovány, okomentovány a shrnuty.

V páté kapitole ve stručnosti popíšeme a shrneme závěry výzkumu, který se zabýval podobnou tematikou - jedná se o výzkum s názvem $\mathrm{Me}$ diální výchova na základních a středních školách ve školním roce 2017/2018, který proběhl pod záštitou České školní inspekce. Výsledky tohoto výzkumu budeme dále komparovat s výsledky námi realizovaného výzkumu. 


\section{1}

\section{Teoretické ukotvení základních pojmů}

Výzkum se zaměřoval na vybrané aktuální problémy mediální výchovy u žáků 2. stupně ZŠ a vztah těchto žáků k médiím s důrazem na sociální sítě. V této kapitole vymezíme základní teoretická východiska pojmů, které s výzkumem souvisejí. Jedná se o pojmy jako média, mediální výchova, mediální gramotnost a sociální sítě. V souvislosti s aktuálními problémy mediální výchovy si vysvětlíme pojmy jako dezinformace, hoax, falešná fotografie, falešný účet na sociálních sítích, mediální stereotyp, reklama a hating (nenávistné př́spěvky na internetu). ${ }^{1}$

\subsection{Média}

Termín médium pochází z latinského přídavného jména medium, což v překladu znamená nacházející se uprostřed nebo střední (Schellmann a kol., 2002, s. 10). Z toho lze vyvodit, že v obecné rovině můžeme médium chápat jako jakýsi kanál nebo technický prostředek.

V širokém slova smyslu mohou být média například peníze, čas, doprava, elektřina - zkrátka všechny prostředky zajištující styk jedné entity s jinou. Tento styk však není primárně komunikační povahy, ale má spíše sociální vliv, mění sociální rovnováhu, rytmus a strukturaci každodenních činností. Příkladem může být objev elektrického světla, který zrušil dosavadní přirozenou hranici mezi dnem a nocí, a tím změnil načasování všech typů práce, které byly na denním světle závislé (Reifová, 2004, s. 139-140).

1 V textu budeme pojmy „hating“ a „nenávistné příspěvky na internetu“ používat jako synonyma. 
V užším slova smyslu slouží média primárně ke komunikaci (nikoliv však ke komunikaci masové) - řadíme sem řeč, neverbální komunikaci, umění, školství, architekturu apod. Pro potřeby této monografie nás však zajímá pojetí médií v nejužším slova smyslu, které média chápe jako prostředky masové či mediální komunikace, tj. média tištěná, elektronická a nová (Reifová, 2004, S. 140). V souvislosti s tím považujeme za důležité vysvětlit, co to jsou masová média. Ta na rozdíl od médií neumožňují vysílání a přijímání na obou stranách, ale staví jednoho z účastníků do role původce sdělení a druhého do pozice př́ijemce, přičemž tento příjemce je tvořen početnou skupinou osob, mezi nimiž jsou slabé či žádné sociální vazby (Jechová, 2010, s. 21). Mezi masová média či jinak řečeno hromadné sdělovací prostředky, masmédia nebo média masové komunikace řadíme noviny, časopisy, rozhlas, televizi, knihy, film, video a také internet, který je v současné době rozvoje informačních a komunikačních technologií velmi častým zdrojem mediálních sdělení.

Jsme si vědomi, že pojmy jako médium a masmédium nelze považovat za synonymní, avšak pro potřeby této publikace je budeme vnímat jako významově rovnocenné varianty. Budeme-li tedy v textu hovořit o médiích, budeme mít na mysli vždy média masová.

V rámci výzkumu pracujeme také s termíny jako veřejnoprávní média a soukromá média. Stručně si zde uvedeme jejich definici. Veřejnoprávní média (nebo také média veřejné služby) jsou zrrízena zákony a jejich hlavním cílem není generovat ekonomický zisk jako u komerčních médií, nýbrž poskytovat veřejnosti objektivní informace a vyváženou nabídku pořadů pro všechny skupiny obyvatel. Mezi veřejnoprávní média patři Česká televize, Český rozhlas (financovány z televizních a rozhlasových poplatků - tzv. koncesionářských poplatků) a Česká tisková kancelár̆, která vydělává na svůj provoz prodejem agenturního zpravodajství (Macek a kol., 2019, s. 273). Mičienka a Jirák (2007, s. 290) dále shrnují, že hlavním úkolem veřejnoprávních médií je sloužit veřejnému zájmu, rozvoji demokracie a národní kultury a odrážet názorovou pluralitu.

Naopak soukromá média (též komerční média) jsou masová média, jejichž hlavním cílem je generovat ekonomický zisk, přičemž primárním zdrojem př́ijmů je prodej reklamy (Macek a kol., 2019, s. 273). Soukromá média nejsou při své práci př́mo ovlivňována státem a základními podmínkami jejich fungování jsou dostatečná sledovanost, poslechovost, čtenost či návštěvnost stránek. Jednoduše, čím více lidí bude tato média konzumovat, tím dražší bude reklamní prostor pro inzerenty a tím více peněz média prodejem získají (Pospíšil, 2011, s. 27).

Vzhledem $\mathrm{k}$ tomu, že $\mathrm{v}$ našem výzkumu pracujeme také s prvky bulváru, vysvětlíme si v závěru této podkapitoly základní rozdíly mezi médii 
seriózními a bulvárními. Mezi seriózní média řadíme takové sdělovací prostředky, které kladou hlavní důraz na objektivitu, přesnou a důkladnou analýzu a přinášejí informace v širším kontextu. Na druhé straně bulvární média se zaměřují především na emoce a využívají témata jako sex, násilí, katastrofy apod. Nebezpečí bulvárních médií tkví v tom, že mohou šírit různé polopravdy či dokonce lež a porušovat tak základní pravidla novinářské etiky (Pospíšil, 2011, s. 28).

\subsection{Mediální výchova}

V odborné literatuře se setkáváme s několika různými definicemi mediální výchovy. Pro nás je stěžejní definice uvedená v Pedagogickém slovníku (Průcha, 2003, s. 119), kde je mediální výchova charakterizována jako výchova k orientaci v masových médiích, $k$ jejich využívání a zároveň $k$ jejich kritickému hodnocení. Jejím cílem je naučit žáky využívat média ke svému sebevzdělávání a seberozvoji, kriticky přistupovat k prezentovaným informacím a zároveň být odolný vůči negativním vlivưm médií, jako je třeba manipulace.

V České republice je mediální výchova důležitou součástí vzdělávání, avšak často jí není věnována dostatečná pozornost. Je jedním z průřezových témat Rámcových vzdělávacích programů základního a středního vzdělávání. Tato témata si kladou za cíl seznamovat žáky s aktuálními problémy současného světa a rozvíjet jejich osobnost. Bývají realizována jako samostatné předměty, projekty, semináře, kurzy, nebo jsou součástí jiných vyučovacích předmětů. Konkrétně průřezové téma Mediální výchova bývá nejčastěji součástí výuky českého jazyka a literatury, společenských věd nebo informatiky.

Vzhledem $\mathrm{k}$ tomu, že se tato publikace zabývá mediální výchovou na základních školách, považujeme za důležité uvést pojetí mediální výchovy tak, jak ji definuje Rámcový vzdělávací program pro základní vzdělávání mediální výchova v základním vzdělávání nabízí elementární poznatky a dovednosti týkající se mediální komunikace a práce s médii (RVP ZV, 2017, s. 137). Vychází se zde z předpokladu, že pro uplatnění jedince ve společnosti je nezbytné umět zpracovat, vyhodnotit a využít podněty přicházející z médií, která jsou zároveň významným socializačním faktorem majícím vliv na jedince či společnost, na vytváření životního stylu a pohledu na svět. Některá média mohou současně vznikat s různými manipulačními záměry, proto je potřeba mediální sdělení posoudit z hlediska záměru jejich vzniku či vztahu k realitě, což vyžaduje značnou průpravu, kterou by měli žáci 
získat prostřednictvím průřezového tématu Mediální výchova v průběhu studia (RVP ZV, 2017, s. 137).

Často dochází k chybné interpretaci mediální výchovy, proto si na tomto místě ve stručnosti uvedeme, co mediální výchova není. Za mediální výchovu nelze považovat nauku o tom, jak co nejefektivněji využívat média v rámci edukace, či nauku o tom, jak média správně obsluhovat a umět s nimi pracovat, zároveň se nejedná o synonymum pro technologie vzdělávání (Niklesová, Bína, 2010, s. 10).

Při studiu odborné literatury jsme se setkali také s definicemi, které uváděly, že cílem mediální výchovy je vybavit žáky mediální gramotností. Na její charakteristiku se podíváme v následující podkapitole.

\subsection{Mediální gramotnost}

Mediální gramotnost je jednou ze základních kompetencí, kterou by si měl člověk žijící v moderní společnosti osvojit. V odborné literatuře se opět setkáváme s jejími různými definicemi.

Poněkud širokou definici uvádí Bína (2005, s. 7), který chápe mediálně gramotného člověka jako někoho, kdo zvládá komunikaci prostřednictvím nosičů slov, písmen, zvuků a obrazů. Užší definice bychom našli u Mičienky a Jiráka (2007, s. 9), podle kterých je mediální gramotnost soubor poznatků a dovedností, jež jsou nezbytné pro orientaci ve světě médií. Jedná se o poznatky, které musí žák získat, aby byl schopen kriticky posoudit mediální sdělení, které mu umožní plné využití potenciálu médií jako zdroje informací, zábavy, vzdělání apod. Získané dovednosti žákovi umožní dosažení kritického odstupu od mediálních obsahů i získání maximální kontroly vlastního užívání médií. Mediální gramotnost v sobě tedy zahrnuje tři aspekty - základní poznatky o fungování médií, znalosti o společenské roli médií a schopnost určit typ prezentovaných sdělení, posoudit jejich věrohodnost a vyhodnotit jejich komunikační záměr. Velmi podobné pojetí bychom našli i v Rámcovém vzdělávacím programu pro základní vzdělávání (2007, s. 137). Podle něj v sobě mediální gramotnost zahrnuje jednak osvojení si základních poznatků o historii, struktuře fungování a společenské roli současných médií, jednak získání dovedností umožňujících aktivní a svobodné zapojení jedince do mediální komunikace. Mimo schopnost kriticky analyzovat a posoudit věrohodnost a komunikační záměr mediálních sdělení v sobě mediální gramotnost zahrnuje také orientaci v mediálních obsazích a schopnost volby odpovídajícího média jako prostředku pro naplnění nejrůznějších potřeb - od sběru informací přes vzdělávání až po naplnění volného času. 
Na závěr této podkapitoly uvádíme výstižnou definici, kterou v rozhovoru na stránkách Revue pro média uvedl Jan Jirák (2004): „Mediální gramotnost začíná tam, kde končí mediální nevinnost."

\subsection{Sociální sítě}

Vzhledem $\mathrm{k}$ tomu, že se v prezentovaném výzkumu námi sledované jevy odehrávají na sociálních sítích, uvedeme si v následujícím textu jejich definici.

Sociální sítě (nebo také sociální média) jsou internetové služby sloužící k vzájemnému propojování uživatelů internetu, a především pak k udržování a navazování různých druhů kontaktů napříč celým světem. Umožňují nám vytvářet uživatelské profily, jejichž prostřednictvím se na internetu můžeme prezentovat, sdílet různé druhy obsahů včetně fotografií a videí, komentovat a hodnotit příspěvky ostatních uživatelů, chatovat s nimi, vytvářet nová virtuální přátelství apod. Podle Černé $(2013$, s. 28) je nejdůležitějším znakem sociálních sítí právě možnost kontaktu s ostatními a sledování toho, co druzí dělají.

Za zmínku stojí také definice socioložek Boydové a Elissonové (2007, s. 211), které sociální sítě charakterizují jako webové služby, jež lidem umožnuují zakládání veřejných či částečně veřejných profilů, vytváření seznamů dalších uživatelů, se kterými chtějí být lidé ve spojení, a zároveň prohlížení seznamů ostatních uživatelů.

Podle výzkumné zprávy České děti v kybersvětě (Kopecký, 2019) patří mezi nejčastěji použivané sociální sítě Facebook, Facebook Messenger a Instagram. Všechny tyto sítě přitom vlastní stejný majitel - zakladatel Facebooku, Mark Zuckerberg. Ve výzkumu pracujeme také se sociální sítí Twitter, která není dětmi přiliš využívaná. Avšak jedná se o sociální sít, kterou ve větší míře využívají politici (tudíž se zde setkáváme také s jejich falešnými účty), a proto jsme ji do našeho výzkumu zahrnuli.

Také je důležité na tomto místě vysvětlit pojem influencer, se kterým v našem výzkumu často pracujeme. Za influencera bývá označován takový uživatel internetu, který dokáže s využitím obsahu, který vytváří, a počtu svého publika, ovlivnit chování dalších uživatelů na internetu. Influenceři mají často velkou komunitu lidí, kteří je sledují, dále obsah sdílejí na určité konkrétní platformě (např. Facebook, YouTube apod.) a vyjadřují se k určitému tématu (např. stravování, fitness, péče o kočky, hraní PC her apod.). 


\subsection{Vybrané aktuální problémy mediální výchovy}

V současné době se v mediální výchově setkáváme s několika novými problémy či trendy, které souvisejí s rozvojem informačních a komunikačních technologií, mezi které řadíme například mobil, počítač, notebook či tablet. Prostřednictvím těchto technologií se můžeme téměř kdekoliv, kde je to možné, připojit na internet a vytvořit si profil na některé ze sociálních sítí, ale také produkovat mediální obsah. Zatímco dříve bylo odpovědností konkrétních vydavatelů médií poskytovat pravdivé a ověřené mediální obsahy v souladu s etickými kodexy zpravodajství a většina populace byla pouhým př́ijemcem těchto obsahů, dnes může tyto obsahy produkovat kdokoliv bez nutnosti poskytovat ověřené informace a disponovat kapitálem. Každý člověk si může vytvořit např́iklad zpravodajský web či stránku na Facebooku a sdílet tam obsah, který může být zavádějící nebo dokonce záměrně nepravdivý, a šíriit tak dezinformace a hoaxy (někdy se používá souhrnné označení fake news) (Kopecký, Szotkowski, 2019, s. 2), které mohou pracovat mimo jiné také s mediálními stereotypy a vést až $\mathrm{k}$ šiření nenávisti v online prostředí. Příkladem může být hoax s titulkem „Romové opět kradou“ (mediální stereotyp), lživě informující o určité události, který se objeví jako příspěvek na sociální síti a pod kterým se následně objeví množství nenávistně orientovaných komentářu útočících právě na Romy. Pro tyto situace se v současnosti stále častěji využívá také termín předsudečná nenávist.

V souvislosti s výše uvedeným se na sociálních sítích můžeme setkat také s falešnými uživatelskými účty, fotografiemi či reklamami. Jejich cílem je, podobně jako je tomu u hoaxů a dezinformací, manipulovat ostatními uživateli a přimět je k často iracionální reakci. Právě falešné fotografie bývají velmi často použity $\mathrm{k}$ podpoření věrohodnosti dezinformací a hoaxů.

Jak můžeme vidět, jednotlivé aktuální problémy jsou velmi úzce propojeny a jejich společným znakem je, že se vyskytují v prostředí internetu a převážně sociálních sítí. Jelikož jsou v dnešní době právě sociální sítě primárním zdrojem informací pro většinu populace a zároveň nejsou schopny oddělit falešný obsah od pravdivého, je důraz na rozvoj mediální gramotnosti v rámci mediální výchovy daleko větší, než tomu bylo dříve. Pouze mediálně gramotný jedinec totiž dovede rozpoznat pravdivé a nepravdivé informace, falešné profily či fotografie a další problémy, se kterými se na internetu může setkat. Také je potřeba říct, že výše zmíněné problémy byly, jsou a budou nedílnou součástí internetového prostoru, a to z toho důvodu, že internet je svobodný a v současné době jej nelze plně regulovat. Právě tato svoboda s sebou přináší i odpovědnost každého jedince naučit se s těmito aktuálními problémy nakládat. 
V následující části kapitoly si představíme vybrané aktuální problémy mediální výchovy podrobněji. Zaměříme se postupně na dezinformace, hoaxy, falešné internetové uživatelské účty a fotografie, mediální stereotypy, reklamu (a pojmy s ní související) a hating. V rámci mediální výchovy je aktuálních problémů samozřejmě daleko více (např́íklad problematika kybernetické bezpečnosti, internetových výzev apod.), avšak my jsme se zaměřili na ty, z našeho pohledu, nejdůležitější a často opomíjené.

\subsubsection{Dezinformace}

V literatuře se setkáváme s několika definicemi dezinformací, které jsou si významově velmi podobné. Dezinformace je podle Slovníku mediální komunikace (Reifová, 2004, s. 45) úmyslně nesprávná či zkreslená informace tajně implementovaná do informační soustavy oponenta se záměrem ovlivnit žádoucím směrem jeho aktivity či názory. Dále se zde uvádí, že dezinformace často napadá oponentovu národní, vlasteneckou či kulturní hrdost a náboženské přesvědčení. Moderní dezinformační kampaň podle Reifové začíná veřejným publikováním určitého skandálního materiálu v některém méně známém médiu. Je-li tato kampaň úspěšná, může se déle šířit a mohou ji přebírat i ostatní média. Je potřeba dodat, že v době sociálních sítí a internetu se tento materiál šírí daleko rychleji, než tomu bylo dříve.

Podle Nutila (2018, s. 18) je dezinformace lživá a falešná informace, která má za cíl ovlivnit názor nejen jedince, ale i celé společnosti. Autor dále uvádí, že dezinformace se významově kryje s pojmem fake news a některými hoaxy. S velmi podobnou definicí dezinformací se setkáváme také v publikaci Být v obraze 2, která vznikla pod záštitou organizace Člověk v tísni. Dezinformací se opět myslí záměrné a systematické šíření nepravdivých informací. Avšak tyto informace jsou vytvářeny státními aktéry nebo jejich odnožemi vůči cizímu státu nebo vůči médiím (Macek a kol., 2019, s. 267).

Gregor $(2018$, s. 8) dodává, že se můžeme setkat také s pojmem misinformace (fáma). Ten má s dezinformacemi společný nepravdivý či zavádějící obsah, avšak fáma je šířena bez vědomí, že se jedná o lež. Mezi fámy můžeme řadit různé "drby“ nebo tzv. urban legends - příběhy o lidech, kterým se stala nějaká zvláštní príhoda.

K šíření dezinformací slouží široké spektrum sdělovacích prostředků přes sociální sítě, televizi, rozhlas až po denní tisk. Ve srovnání s minulostí se tyto zprávy šírí daleko rychleji. Dříve mohlo nějakou dobu trvat, než se k nám zpráva dostala, avšak dnes se $\mathrm{k}$ ní můžeme dostat během pár minut. 
Př́ijemcem těchto zpráv může být kdokoliv - od široké neinformované veřejnosti po určitou specifickou část obyvatelstva (Gregor, 2018, s. 8).

Aby byla dezinformace uvěřitelná, musí být splněny tyto tři podmínky (Gregor, 2018, s. 8-9):

- Musí se zakládat částečně na věrohodných informacích - Pokud např́klad napíšeme, že kandidáta na prezidenta uneslo UFO, tak nám př́jemci př́liš věřit nebudou. Pokud však zpochybníme důvěryhodnost financování kandidátovy kampaně a vymyslíme svědectví falešných svědků, můžeme kandidáta v očích svědků značně zdiskreditovat.

- Musí zapadat do kulturního kontextu - Pokud obviníme osoby ve Francii z pálení bible, bude to mít menší dopad, než kdybychom v Pákistánu někoho obvinili z pálení Koránu.

- Musí se $\mathrm{k}$ nám dostat $\mathrm{z}$ více kanálů - $\mathrm{Z}$ čím více kanálů (ze sociálních sítí, novin, rozhlasu apod.) se k nám daná informace dostane, tím je pro nás věrohodnější.

Avšak dezinformace v žádném případě nejsou novým fenoménem. S jejich pomocí se vládci, vojevůdci i další významné osobnosti napříč historií uchylovali k oklamávání svých protivníků. Snažili se tak získat výhodu ve válce či politickém souboji. Nejranější zmínka o dezinformacích pochází z roku 1923, kdy v rámci ruské tajné policie a zpravodajské státní služby Státní politická zpráva (GPU) vzniklo speciální oddělení, jehož cílem bylo šiřit dezinformace v rámci zpravodajských operací. Činnost těchto oddělení měla za cíl ovlivnit rozhodovací procesy $\mathrm{v}$ cizích státech. Až do osmdesátých let bylo slovo dezinformace chápáno především jako aktivita spojená se zpravodajským řemeslem (Gregor, 2018, s. 9-10).

V souvislosti s dezinformacemi se setkáváme také s pojmem propaganda. Reifová (2004, s. 45) dokonce tvrdí, že dezinformace je nástrojem propagandy. Smyslem propagandy podle Alvarové (2017, s. 12-14) není jen měnit veřejné mínění, ale především s ním jemně manipulovat. Někdy tato manipulace může spočívat jen v prohloubení a vyostření názorů, které jsou již mezi lidmi rozšiřeny, stačí je jen zesílit. Propaganda disponuje velkým množstvím technik práce s pravdou, ke které se tu a tam přidá menší lež, správný podtext, mírně upravená fotka apod. Zároveň propaganda využívá toho, že každý člověk má určité slabé místo, prostřednictvím kterého je možné ho ovlivnit. Tvůrci propagandy tato slabá místa znají a mluví jazykem, kterým nás mohou manipulovat.

Alvarová (2017, s. 13) dále píše, že „propagandu konzumuje skoro každý. Lidé, kteří povrchně čtou. Lidé, které ve škole nebavila fakta. Středoškoláci, 
kteří nemají dost informací a nevědí,jak se informace ověřují. Staří lidé, kteří už cítí, že je tělo tolik neposlouchá, a pronásleduje je strach. Ale konzumují ji i ti, kteří přeceňují své vzdělání a myslí si: ,Já mám přece dvě vysoké školy, mně se to stát nemůže... “ V této souvislosti považujeme za podstatné opět zmínit, nakolik je kvalitní mediální výchova už od raného věku důležitá.

\subsubsection{Hoax}

Podobně jako u dezinformace, tak i u hoaxu se setkáváme s definicemi, které se $\mathrm{z}$ hlediska významu takřka neliší. Hoax je zpráva obsahující falešné nebo zkreslené informace, která obvykle zahrnuje žádost o další šíření a sdílení mezi co nejvíce osob. Cílem takové zprávy může být pobavit či ovlivnit názory nebo postoje př́ijemců. Hoaxy často také varují před nějakým smyšleným nebezpečím, a tím vyvolávají paniku a strach (Macek a kol., 2019, s. 268).

Někteří autoři neuvádí rozdíly mezi hoaxem a dezinformací, avšak na rozdíl od dezinformace bývá klasický hoax většinou nezávislý na politické situaci či celospolečenských krizích. Může internetem putovat řadu let a objevovat se v různých vlnách (Kopecký, 2019). Není to však pravidlem a hranice mezi dezinformací a hoaxem je velmi tenká, ne-li žádná. Zároveň hoax může být nástrojem propagandy stejně jako dezinformace.

Nutil (2018, s. 137) popisuje hoax jako záměrně vytvořený podvod, který se vydává za pravdu. V širokém významu pak zahrnuje i fámu, mystifikaci, falešnou zprávu, žert, novinářskou kachnu nebo poplašnou zprávu. Setkat se můžeme i s podvrženými citáty slavných osobností, upravenými videi či fotografiemi vytrženými z kontextu a doplněnými nepravdivým popiskem. S tím souvisí i obsah hoaxů, který může být různý. Může se jednat o zábavné informace, varování před urgentním nebezpečím, falešné prosby o pomoc, zprávy obsahující citové vydírání, lživé petice nebo třeba varování před virovým onemocněním (Gregor, 2018, s. 45).

Další definici uvádějí Kopecký a Szotkowski (2019, s. 2), kteří hoax definují jako nepravdivou zprávu, jejímž primárním cílem je šírit paniku, vystrašit př́ijemce a donutit ho k unáhleným a často iracionálním reakcím. Hoax většinou obsahuje varování před neexistujícím nebezpečím, nepravdivé informace, např. o aktuálních celospolečenských problémech, nebezpečné návody nebo různé kanadské žertíky, jejichž cílem je pobavit publikum.

Aby se hoax úspěšně šíril a zaujal pozornost př́ijemců, musí podle Nutila (2018, s. 140) splňovat určitá kritéria: 
- Hoax musí obsahovat lákavé, emotivní až dramatické téma (což má společné s bulvárem), které láká pozornost příjemců zcela automaticky. Využiván je proto princip takzvaných $3 \mathrm{~S}$ - strach, smrt, sex.

- Hoax musí mít neodolatelný titulek, který opět působí na emoce příjemců. $V$ této souvislosti můžeme hovořit o tzv. odkazových návnadách (click-bait), které využívají přirozené lidské zvědavosti dozvědět se na základě šokujícího titulku o dané události více. Cílem těchto návnad není nic jiného než zvyšovat návštěvnost webů, a tedy i př́jem z online reklamy umístěné na těchto webech. Bohužel, na těchto návnadách založila svůj byznys model řada webů, které se však neobtěžují s poskytováním pravdivých a objektivních informací a jde jim převážně o finanční zisk.

- Hoaxy často využívají princip autority. To znamená, že se zaštitují známými osobnostmi, vědci, anonymními experty či velkými institucemi a firmami. Cílem je zvýšit důvěryhodnost daného hoaxu.

- Hoax apeluje na čtenáře, aby jej sdíleli a šířili dál. Tento apel může být spojen i s tvrzením, že se jedná o informaci, kterou oficiální kruhy (média, vláda, farmaceutické společnosti apod.) tají.

Mezi slavné hoaxy, které se šířly českým internetem, patří například hoaxy o tom, že EU chce zrušit písmeno Ř, že za sběr hub můžeme jít do vězení, že země je placatá, že v tramvajích jsou nastraženy injekční stř́́kačky s virem HIV apod. My jsme v našem výzkumu použili hoax či dezinformaci (v našem výzkumu termíny nerozlišujeme) o zlevněném másle pro Romy, dále ukázku dezinformační stránky na Facebooku We Are Here At Home.com a lživou zprávu o koronaviru objevující se na dezinformačním zpravodajském portále euRABIA.

\subsubsection{Falešné internetové uživatelské účty}

S falešnými internetovými uživatelskými účty (dále jen falešné účty) se setkáváme na mnohých sociálních sítích, at' už jsou to Facebook, Twitter, Instagram a další, přičemž se odhaduje, že až 10 \% účtů na sociálních sítích je falešných. Může se jednat o účty veřejně známých osobností (např. politiků, umělců, youtuberů apod.), ale i obyčejných lidí. My jsme se v našem výzkumu zaměřili na falešné účty politiků, za nimiž mohou stát profesionálové, nebo lidé, kteří jsou motivováni finanční odměnou či pozorností ostatních uživatelů. Smyslem těchto účtů je manipulovat s míněním uživatelů, kteří tyto účty sledují a neuvědomují si, že se jedná o účty falešné, za nimiž 
nesedí konkrétní člověk na profilové fotografii (v našem př́padě konkrétní skutečný politik). Pokud např́klad člověk, schovávající se za falešným účtem nějakého politika, napíše určitý kontroverzní příspěvek, může to vyvolávat negativní emoce v ostatních uživatelích, a vést tak $\mathrm{k}$ šíření nenávisti či paniky. Avšak některé falešné účty nemají za cíl negativně ovlivňovat ostatní, ale vznikají za účelem pobavit své sledující. U těchto účtů však většinou velmi rychle poznáme, že se jedná o satiru.

S falešnými účty obyčejných lidí se lze setkat v souvislosti s kybergroomingem. Tento termín označuje chování uživatelů internetu, které má v oběti vyvolat falešnou důvěru, a přimět ji tak k osobní schůzce (Kopecký, 2010, s. 3). Útočník si často vybírá oběti výrazně mladší, než je on sám, či oběti stejného pohlaví, proto si vytváří falešný účet, na kterém o sobě uvádí nepravdivé osobní údaje, jako jsou jméno, př́ijmení, věk, bydliště či fotografie obličeje. Tyto fotografie stahuje bud' z jiných uživatelských účtů, nebo je získává od svých obětí.

Rozeznat falešné účty veřejně známých osobností bývá často jednodušší, než rozeznat falešné účty obyčejných lidí, protože některé sociální sítě jsou schopny odlišit oficiální účet veřejně známé osobnosti od účtu falešného, což se u profilů obyčejných uživatelů neděje. Např́́klad Facebook, Instagram a Twitter tyto oficiální účty označují ověřujícím symbolem (tzv. verified button) - malý modrý puntík s bílou fajfkou uprostřed nacházející se hned vedle jména dané osoby. Avšak i tento symbol lze zfalšovat, proto bychom si jej vždy měli ověřit tak, že na něj najedeme kurzorem myši a pokud se nám zobrazí rámeček „ověřeno“, jedná se o oficiální účet. Dále nám může napovědět počet sledujících, fotografie a příspěvky uživatele a celkový vzhled daného účtu.

Pro potřeby našeho výzkumu jsme zvolili falešný facebookový účet prezidenta ČR Miloše Zemana a falešný twitterový účet premiéra ČR Andreje Babiše. Detailněji tyto profily popíšeme až v kapitole zabývající se rozborem jednotlivých položek v dotazníku.

\subsubsection{Falešné fotografie}

Falešnými fotografiemi se myslí takové fotografie, které byly nějakým způsobem upraveny, avšak mohou být chápány i v kontextu fotografií nacházejících se na falešných účtech na sociálních sítích. Jejich společným účelem je opět ovlivnit naše vnímání a manipulovat námi.

Podle Boese (2019, s. 92-93) se nejstarší manipulace s fotografií odehrávala ještě před jejím samotným pořízením, kdy fotograf naaranžoval určitou 
scénu např́iklad pomocí různých modelů nebo výstřižků. Tato technika byla použita u slavné fotografie víl z Cottingley, která zachycovala dívku, kolem které tancují malé víly. Mohlo se tedy jednat o důkaz, že tyto nadpřirozené bytosti opravdu existují. Odborníci zkoumající tuto fotografii nenašli žádnou známku toho, že by byla falešná, protože nebyla. Byla vytvořena tak, že její autor nejdříve nakreslil víly na papír, potom je vystřihl a papírové figurky připevnil na místa před fotoaparátem.

Jako další způsob falšování fotografií, aniž by se musel upravovat samotný obraz, Boese (2019, s. 94) uvádí doplnění fotografie o vymyšlený titulek, kdy se může nevinný snímek proměnit v důkaz strašného činu. Jako př́klad uvádí fotografii dětí stojících v oceánu s rukama nad hlavou, která se objevila roku 1913 v newyorském listu American. Titulek uváděl, že děti byly do moře nahnány mexickými vojáky, kteří je vzápětí střelili do zad. Později bylo prokázáno, že se jedná o obyčejnou fotografii z dovolené u moře, na níž si děti hrály v príboji a ruce nad hlavu zvedly, aby momentka získala na zajímavosti.

Naaranžování uměle vytvořené scény či lživý titulek představují efektivní metody podvodů s fotografiemi, ale nejčastěji používanou technikou zůstává manipulace s obrazem. Editory fotografií typu Photoshop a další dokážou k snímku přidávat objekty, nebo je vymazávat, měnit barvu, pohybovat věcmi apod. Díky tomu se fenomén manipulace $s$ fotkami v posledních třech desetiletích exponenciálně rozrostl (Boese, 2019, s. 95). Př́kladů takových fotografií je velké množství. Například my jsme pro potřeby výzkumu použili upravenou fotografii uprchlíků na střeše vlaku v Chebu, která se začala internetem šírit v roce 2015 a vyvolávala velmi negativní reakce. Avšak jednalo se o fotomontáž, kdy původní fotografie, pocházející z Indonésie, byla doplněna o fotografii českého vlaku. Dále jsme použili upravenou fotografii obří kočky Snowball a fotografii A. Einsteina s falešným citátem.

Pokud chceme určit, zda je fotografie zmanipulovaná, uvádí Boese (2019, s. 96-97) řadu vodítek. Nejdříve bychom se měli zaměřit na osvětlení fotografie. Pokud objekty na fotce vypadají tak, že je osvětluje různý zdroj světla, nebo se stíny táhnou z různých směrů, může se jednat o fotografii, která byla upravená. Všímat bychom si měli i pixelace a zrnitosti objektů. Pokud něco působí ostřeji či zrnitěji než všechno kolem, bude to tím, že je to do fotky vložené. Vyhledávat bychom měli také opakující se vzory, což může být zapříčiněno použitím funkce klonování. Nakonec bychom měli pátrat po deformovaných nebo chybějících částech těla. Padělatelé fotografií často bezděky odstřihují nebo přidělávají části těla jako ruce nebo nohy (viz slavná fotografie z roku 2018 nacházející se v časopise Vanity Fair 
a zachycující třírukou moderátorku Oprah Winfrey a třínohou herečku Reese Witherspoon).

\subsubsection{Mediální stereotypy}

Podle Pedagogického slovníku (Průcha, 2003, s. 230) pojem stereotyp označuje vnímání členů určité společenské skupiny tak, jako by byli všichni její členové stejní. Zahrnuje v sobě také jednání s těmito členy takovým způsobem, jako by se nevyznačovali žádnými jinými než skupinovými charakteristikami. Dále můžeme stereotyp vnímat jako vykonávání činnosti stále stejným způsobem, který nevyžaduje hlubší přemýšlení.

Macek a kol. (2019, s. 273) popisují stereotyp jako konvenční, ustálený a často zjednodušený názor či postoj, který se vztahuje na skupinu jako celek. Zároveň jsou stereotypy většinou dlouhodobé a mají hlubší kořeny v určité kultuře. V sociální praxi se vztahují především ke členům menšin nebo subkultur, kdy se často poukazuje na jejich odlišnéjednání, kteréje prezentovánojako divné nebo nevhodné, a tím je zároveň posilován většinový životnístyl, který je vnímán jako jediný správný a normální. V chování se pak tyto stereotypy mohou negativně projevovat jako diskriminace a předsudky ve vztahu k druhým. Následně pak mohou být východiskem všech forem diskriminačníhojednání.

Mediální stereotypy jsou takové stereotypy, se kterými pracují média, která mají tendenci je přejímat a šířit. Jsou využivány stereotypy náboženské, etnické, genderové, sexuální orientace, vázané na vzdělání, bydliště, sociální status apod. Rovněž bývají vybírány závažná celosvětová témata jako migrace nebo terorismus. Negativní stereotypy v titulcích mohou být pak projevem bulvarizace, tedy snahou nabídnout příjemcům povrchní či šokující obsah. Tito př́ijemci si často chtějí potvrdit své postoje a názory, proto jsou články potvrzující jejich stereotypy přijímány lépe než ty, které se snaží tyto stereotypy nabourat.

Podle Macka a kol. (2019, s. 207) se stereotypy v médiích týkají:

- Výběru událostí, které se do médií dostanou - Výběr těchto událostí se řídí novinářskými rutinami (např. negativní zprávy bývají přitažlivější než pozitivní apod.) a mediální logikou. Stereotypy v médiích mohou vznikat v důsledku toho, že novináři ztrácejí objektivitu a sami vidí danou problematiku optikou stereotypů. Také mohou být projevem pohodlnosti novináře, který může používat zavedené postupy místo vytváření jiných, nebo který nahlíží na určitý problém z obvyklého a zavedeného úhlu pohledu, než aby se snažil být originální. 
- Výběr mluvčích, kteří se $\mathrm{k}$ událostem vyjadřují - V novinářské praxi se často setkáváme $s$ tím, že mezi oslovovanými jsou politici, a naopak zástupci menšin jsou ve zpravodajství opomíjeni nebo zmiňováni ve velmi specifických kontextech.

- Jazykové a obrazové ztvárnění mediálního sdělení - Často se setkáváme s tím, že například Romové se v médiích objevují ve dvou polohách, a to bud' jako nesocializované osoby přidávající starosti svému okolí, nebo jako etnikum s hudebním cítěním a rozvinutým folklorem zachycené na záběrech $\mathrm{z}$ festivalů romské kultury. Politici mohou být zobrazováni jinak než sportovci, ženy popisovány jinak než muži apod.

Mediální stereotypy se týkají také toho, jakým způsobem média konzumujeme - den začínáme poslechem stále stejné rozhlasové stanice, cestou do práce čteme stále stejné noviny, během dne čteme příspěvky na stále stejných internetových portálech a usínáme při sledování stále stejné televizní stanice (Macek a kol., 2019, s. 208). V tomto smyslu se mluví o tom, že média konzumujeme stereotypně, což se projevuje například tím, že se uzavíráme jakémukoliv odlišnému pohledu, který nám mohou nabídnout jiná média.

\subsubsection{Reklama}

Reklama je podle Slovníku mediální komunikace (Reifová, 2004, s. 209-210) definována jako způsob persvazivní komunikace, během níž jeden subjekt (komerční či nezisková organizace, popř. soukromá osoba) nabízí svůj produkt, službu nebo ideu veřejnosti s cílem přimět ji ke změně postojů či nákupního chování. Tato nabídka se odehrává především prostřednictvím masové komunikace a její zadavatel za zvlášt' označené místo v mediálním obsahu většinou platí.

McQuail (2009, s. 578) definuje reklamu jako placenou propagaci zboží či služeb v médiích, která je cílena na spotřebitele a která má různé cíle, jako vytvořit povědomí a představu o značce nebo vyvolat pozitivní asociace a povzbudit žádoucí chování spotřebitelů. Funkcí reklamy je tedy ovlivnit přijemce tak, aby se choval určitým způsobem.

Podle toho, v jaké oblasti se reklama uplatňuje, rozlišujeme reklamu komerční, politickou a sociální. S reklamou komerční se setkáváme nejčastěji. Jejím cílem je upoutat pozornost veřejnosti na určitý výrobek či službu s cílem podpořit nákup. V politické reklamě jde převážně o prezentaci politických stran, jejich postojů a cílů. Lze říct, že se v tomto případě jedná o součást propagandy. Reklama sociální se pak snaží upozornit na určitý 
společenský problém a ovlivnit postoje nebo chování veřejnosti v určité oblasti (Mičienka, Jirák, 2007, s. 244).

Reklama také bohatě využívá poznatky z oblasti psychologie či sociologie. Mičienka a Jirák (2007, s. 245) uvádějí, že pro psychologii dospívajících je typická obava z neúspěchu ve společnosti a ze sociální izolace. Mladý adolescent prožívá úzkost z možného odmítnutí u opačného pohlaví, vyčlenění ze skupiny vrstevníků apod. Tvůrci reklam s tímto rozpoložením pracují a prezentují některé výrobky a služby jako pojistku proti neúspěchu v socializaci. Bartošek (2010, s. 107) však uvádí, že problém reklam se netýká jen adolescentů, ale i dětí od nejútlejšího věku. Ty podle něj do určitého věku bezmezně věří všemu, co jim reklama předkládá, proto se různé regulační orgány snaží ovlivňovat množství a typy reklam, ve kterých vystupují děti, která je určena přímo dětem a která má za cíl skrze děti působit na rodiče.

McQuail (2009, s. 578) dále dodává, že reklama je rozporuplná i z několika dalších důvodů: př́ijemci si ji obvykle nepřejí a může na ně působit podprahově; má propagandistický charakter a je podezírána z manipulace a klamání; její obsah může být zavádějící či stereotypní apod. Proto jsme se ve výzkumu zaměřili převážně na problémy, které s reklamou souvisejí, a to na klamavou reklamu, sexismus v reklamách, product placement a okrajově také na reklamu na sociálních sítích.

Podle § 2977 Občanského zákoníku (č. 89/2012 Sb.) je klamavá reklama taková reklama, která souvisí s podnikáním nebo povoláním, sleduje podpořit odbyt movitých nebo nemovitých věcí nebo poskytování služeb, včetně práv a povinností, klame nebo je způsobilá klamat podáním nebo jakýmkoli jiným způsobem osoby, jimž je určena nebo k nimž dospěje, a tím i zřejmě způsobilá ovlivnit hospodářské chování takových osob. Taková reklama tedy ovlivňuje spotřebitele pomocí klamu a je posuzována z různých hledisek dostupnost, povaha, provedení, výrobní postup, datum výroby, použitelnost, množství, ceny, podmínek dodání apod. Zkrátka je posuzována podle toho, jaké nepravdivé údaje obsahuje a do jaké míry byla ve spotřebiteli vyvolána klamná představa o realitě.

Klamavá reklama se může týkat ceny výrobku (př. v letáku je uvedena jiná cena, než za kterou je výrobek skutečně prodáván); složení výrobku (př. na obalu ovocné tyčinky je uvedeno, že je ze 100 \% složena z ovoce, ze složení však zjistíme, že obsahuje ovoce jen z 5 \%); účinku výrobku (př. tabletky, které slibují zhubnutí 15 kg během jednoho týdne); nabídky kurzu či seminár̆ů vedených člověkem s odborným vzděláním v dané problematice, i když toto vzdělání nemá; slib obchodníka, že koupí výrobku přispějete na charitativní účely, ačkoliv tomu tak není apod. V našem výzkumu jsme jako ukázku klamavé reklamy zvolili webovou stránku nabízející hubnoucí kúru, 
pomocí níž zhubneme 14 kg za 28 dní. Podrobněji si tuto ukázku popíšeme v části monografie věnující se výzkumu.

Dalším pojmem, který souvisí s reklamou, je tzv. product placement. Dle Mičienky a Jiráka (2007, s. 280) se jedná o takovou formu reklamy, při níž je určitý výrobek, služba či logo umístěno do uměleckých děl (například do seriálů, filmů, zábavních pořadů, videoher apod.), které samy o sobě nemají reklamní charakter. Stává se tak, že divák často ani nezaregistruje, že se mu během konzumace určitého uměleckého díla dostane také velkého množství reklam. Jedním z důvodů, proč autoři do svých děl product placement zařazují, je to, že na základě smlouvy s výrobcem daného produktu či služby může autor zaplatit značnou část svých nákladů na tvorbu daného díla.

S pojmem product placement bývá spojována také skrytá reklama. Skrytá reklama je taková reklama, u níž lze jen obtížně určit, zda se jedná o reklamu, protože není jako reklama označena (Macek a kol., 2019, s. 272) a je na rozdíl od product placementu dle zákona zakázána. V ČR je product placement povolen od roku 2010, ale vztahují se na něj určitá pravidla. Jedním z nich je, že musí být vždy uvedeno, že dané dílo obsahuje product placement (např. pomocí zkratky PP). V našem výzkumu jsme použili screenshot pořadu ČTı Toulavá kamera, který obsahuje právě zkratku PP.

Dalším problémem, který s reklamou souvisí, je sexismus, kdy jsou využívány obrazy sexualizovaného těla (v českém prostředí jsou v tomto smyslu zobrazovány hlavně ženy), které nemají s nabízeným produktem žádnou souvislost (např. polonahá žena je zobrazena v souvislosti s prodejem elektroniky). Můžeme zde hledat také souvislost s dřive zmíněnými mediálními stereotypy, kdy se setkáváme s tím, že sexistické reklamy jsou založeny na zjednodušených představách o ženách či mužích (např. ženy mohou být spojovány převážně s vařením a úklidem, muži s opravou auta apod.). Tento druh reklam tak může stereotypní představy o mužích a ženách upevňovat a ovlivňovat naše vnímání role muže a ženy ve společnosti.

Okrajově se podíváme také na reklamu na sociálních sítích, kterou sdílí influenceři. V současné době se setkáváme s tím, že influenceři mohou mít z reklam na svých účtech na sociálních sítích určitý zisk, který jim může pokrýt veškeré životní náklady. Marketingové agentury jsou si zároveň vědomy velké propagační síly influencerů, a proto tuto formu propagace svých výrobků využívají stále častěji. Funguje to kupříkladu tak, že se oblíbená influencerka vyfotí s lakem na nehty, přidá k této fotografii recenzi výrobku a za to dostane od výrobce určitou finanční částku. Vznikají tak diskuze ohledně autentičnosti těchto influencerů v tom smyslu, nakolik jsou přesvědčeni o kvalitě daného výrobku a nakolik jim jde především o finanční odměnu. V ČR platí, že by takováto forma reklamy měla být ozna- 
čována, protože jinak může být považována za klamavou. Influencer by tedy reklamu měl jasně označit např́klad pomocí hashtagů \#ad, \#spoluprace, \#reklama, \#sponzoring nebo \#sponzorovanyobsah. Další možností je využít funkci označení „placeného partnerství“, kterou nabízí Instagram, nebo přímo v příspěvku uvést, že se jedná o reklamu (Bezuchová, 2020).

\subsubsection{Hating}

V současné době se stále častěji setkáváme také s tzv. hatingem, který je jednou $\mathrm{z}$ forem agrese $\mathrm{v}$ online prostředí (dalšími formami jsou například kyberšikana, kybergrooming apod.) a který se projevuje nenávistnými příspěvky na sociálních sítích, komentáři v diskuzích, chatech apod. Tyto projevy nenávisti jsou nejčastěji zaměřeny proti nejrůznějším náboženským, etnickým, sociálním nebo sexuálním skupinám, ale mohou cílit prakticky na každého člověka bez ohledu na to, jestli je členem zmíněných skupin. Hating může úzce souviset také s hoaxy a dezinformacemi, které mohou mít v určitých případech za cíl tuto nenávist vyvolávat (např́iklad pod hoaxem o Romech, kteří nemusí v obchodě platit za máslo, se objevila řada nenávistných facebookových príspěvků).

Za český ekvivalent slova hating lze považovat slovo nenávist, která je podle Encyklopedického slovníku (1993, s. 736) definována jako intenzivní emoce projevující se zlostí, hněvem, nepřátelstvím vůči osobě, sociální skupině nebo objektu. Bývá charakterizována radostí z neštěstí druhého a přáním způsobit bolest nenáviděnému objektu.

S hatingem úzce souvisí i tzv. hate speech, přičemž oba pojmy mohou být chápány jako synonyma. Podle Hrdiny a kol. (2015, s. 8-9) je hate speech takový projev, který veřejně vyhrožuje nebo ponižuje skupinu obyvatel na základě rasy, náboženského vyznání či etnika, volá po násilných nebo perzekučních opatřeních vůči těmto skupinám nebo podněcuje nenávist či opovržení vůči nim. Za nenávistné projevy můžeme považovat ty, které obsahují přirovnání lidí ke zvířatům, hmyzu apod. a vsugerování čtenářům, že jim od nějaké skupiny hrozí nebezpečí. Dále autoři uvádějí, že se v ČR zdaleka nejedná o nový fenomén, avšak spolu s rozmachem komunikace na sociálních sítích můžeme pozorovat novou dynamiku jeho širrení. V současnosti můžeme pozorovat nenávistné projevy vůči migrantům, které souvisí s xenofobními tendencemi a také se stereotypy, které se v médiích objevují. V námi realizovaném výzkumu byla jako ukázka hatingu použita facebooková diskuze, která se objevila pod fotkou tabla žáků l. třídy ZŠ v Teplicích. 
V rámci hatingu mluvíme také o relativně novém fenoménu, a tím jsou internetoví trollové. Podle Kopeckého (2011) termínem troll označujeme uživatele internetu, který úmyslně narušuje diskuzi či chat vkládáním nevhodného obsahu s cílem vyprovokovat ostatní účastníky chatu a rozpoutat emocionálně vypjaté reakce od ostatních účastníků diskuze. Výsledkem chování trolla je pak narušení diskuzního fóra, které se změní v prostor nenávistné komunikace. 


\section{2}

\section{Metodologie výzkumu}

V této kapitole se zaměříme na popis výzkumné procedury. Nejprve si vyjmenujeme výzkumné cíle, na které navážeme výzkumnými otázkami (problémy), následně popíšeme výzkumný vzorek a výzkumný nástroj. V závěru kapitoly nastíníme časový harmonogram výzkumu a způsob zpracování výzkumných dat.

\subsection{Výzkumné cíle a problémy}

Hlavním cílem výzkumu bylo zmapovat, do jaké míry se žáci 2. stupně ZŠ orientují ve vybraných aktuálních problémech mediální výchovy a mediální gramotnosti a jaký je vztah těchto žáků k médiím s důrazem na sociální sítě. Zaměřovali jsme se především na tyto aspekty:

- jaký zdroj informací používají žáci nejčastěji,

- zda si žáci ověřují pravdivost informací, fotografíi a profilů uživatelů na sociálních sítích a podle jakých kritérií se rozhodují,

- zda jsou schopni na základě názorných př́íkladů rozeznat dezinformace, hoaxy, falešné internetové profily a fotografie, product placement, sexismus v reklamách, klamavou reklamu, mediální stereotypy, hating a veřejnoprávní média,

- zda žáky ovlivňují influenceři, které na sociálních sítích sledují (influenceři jsou lidé, kteří mají na sociálních sítích určitý vliv a větší množství uživatelů, kteří je sledují, tzv. followerů),

- zda žáci píšou nenávistné příspěvky na internet, 
- zda ovlivňuje četba nenávistných příspěvků vztah žáků k dané skupině (etnické, náboženské apod.),

- zda žáci někdy byli obětí nenávistných příspěvků na internetu.

Důležitým předpokladem pro naplnění těchto cílů bylo studium odborné literatury za účelem poskytnutí základních teoretických poznatků k problematice mediální výchovy. Zabývali jsme se mediální výchovou z pohledu odborných disciplín, které ji zkoumají, ale také z pohledu didaktického a pedagogického. Součástí byla také četba odborných publikací z oblasti kvantitativního výzkumu a statistiky.

Praktické cíle výzkumu můžeme chápat jako synonymum pro výstupy výzkumu a jejich aplikační potenciál. Prostřednictvím odborných příspěvků, vystoupení na tuzemských i zahraničních konferencích a publikování této monografie chceme přispět k vyšší informovanosti o této doposud okrajově probádané problematice. Dále také chceme prostřednictvím našeho výzkumu přispět k otevření úvah pedagogických pracovníků, nakolik je výuka mediální výchovy na ZŠ efektivní, zda odpovídá aktuálním celospolečenským problémům a trendům, a nabídnout tak prostor pro zlepšení.

Nelze opomenout také personální cíle výzkumu, které lze chápat jako příležitosti, prostřednictvím nichž byla řešením celého výzkumu obohacena sama navrhovatelka, a to z hlediska odborných, sociálních a komunikativních kompetencí. Můžeme tvrdit, že personálním cílem bylo rozvíjení vědeckých kompetencí navrhovatelky, které mohou přispět ke zkvalitnění plánované disertační práce, ale také $\mathrm{k}$ účasti navrhovatelky na dalších výzkumných šetřeních. Následná prezentace výsledků sloužila k rozvoji komunikativních kompetencí navrhovatelky v cizím jazyce, stejně tak přispěla $\mathrm{k}$ rozšíření kontaktů a získávání cenných zkušeností v průběhu interakce s ostatními členy vědecké komunity.

V souvislosti s výše uvedeným byly výzkumné problémy (výzkumné otázky) následující:

A. Do jaké míry se žáci 2. stupně ZŠ orientují ve vybraných aktuálních problémech mediální výchovy?

B. Jsou žáci 2. stupně ZŠ schopni na základě názorných příkladů rozeznat dezinformace, hoaxy, falešné internetové profily a fotografie, product placement, sexismus v reklamách, klamavou reklamu, mediální stereotypy, hating a veřejnoprávní média?²

C. Jaký zdroj informací používají žáci 2. stupně ZŠ nejčastěji?

2 Výzkumné podotázky pojící se k této výzkumné otázce nalezneme ve třetí kapitole. 
D. Ověřují si žáci 2. stupně ZŠ pravdivost informací, fotografií a profilů uživatelů sociálních sítí na internetu a podle jakých kritérií se rozhodují?

E. Ovlivňují žáky 2. stupně ZŠ influenceři, které na sociálních sítích sledují?

F. Chtějí si žáci 2. stupně ZŠ zakoupit výrobek, který propaguje jejich oblíbený influencer na sociálních sítích? Domnívají se, že je influencer přesvědčen o kvalitě tohoto výrobku?

G. Z jakého důvodu, dle mínění žáků 2. stupně ZŠ, influencer daný výrobek propaguje?

H. Napodobují žáci 2. stupně ZŠ stravovací návyky oblíbeného influencera, kterého na sociálních sítích sledují?

I. Drželi žáci 2. stupně ZŠ dietu nebo dodržovali cvičební režim, aby se podobali svému oblíbenému influencerovi, kterého sledují na sociálních sítích?

J. Píšou žáci 2. stupně ZŠ na internet nenávistné příspěvky? Pokud ano, na koho tyto příspěvky útočí?

K. Ovlivňuje četba nenávistných příspěvků vztah žáků 2. stupně ZŠ k dané skupině (etnické, náboženské apod.)?

L. Byli žáci 2. stupně ZŠ někdy obětí nenávistných příspěvků na internetu? Pokud ano, čeho se tyto př́spěvky týkaly?

\subsection{Výzkumný vzorek}

Základní soubor tvořili žáci 2. stupně ZŠ v České republice - tedy žáci 6., 7., 8. a 9. tříd. Jednotlivé školy byly oslovovány prostřednictvím e-mailové komunikace.

V rámci předvýzkumu, kterého se zúčastnilo 21 respondentů, jsme pomocí směrodatné odchylky určili rozsah výběru, který při 99\% spolehlivosti výsledků a s přesností $\pm 0,2$ bodu činí 672 respondentů.

Samotného výzkumu se poté zúčastnilo 1464 respondentů, z nichž jsme 20 vyřadili z důvodu př́liš vysokého věku. Výzkumný vzorek tedy sestával z 1444 respondentů, z nichž bylo 56,44 \% dívek a 43, 56 \% chlapců. V 6. tř́ídě bylo 23,61 \% žáků, v 7. třídě 25,9 \%, v 8. třídě 28,95 \% a v 9. třídě $21,54 \%$. Následující graf znázorňuje věkové rozložení respondentů - 4,50 \% respondentů bylo ve věku 11 let, $22,23 \%$ ve věku 12 let, $25,62 \%$ ve věku 13 let, $27,15 \%$ ve věku 14 let, $19,18 \%$ ve věku 15 let a 1,32 \% ve věku 16 let. 
Graf č.1 Věk respondentů

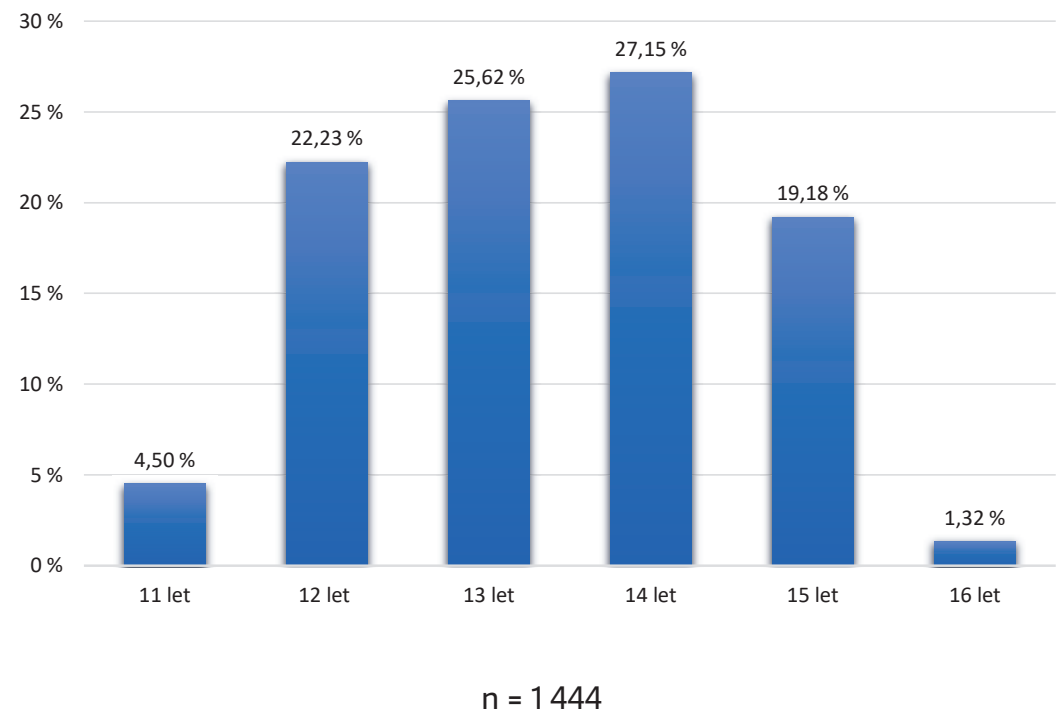

$Z$ vesnice pochází 44,67 \% respondentů, z města 55,33 \% respondentů. Z hlediska regionálního rozložení byly zastoupeny všechny kraje kromě Ústeckého, přičemž nejvíce respondentů bylo z Olomouckého, Středočeského, Jihomoravského a Pardubického kraje, nejméně pak z Libereckého kraje. Detailnější rozložení můžeme vidět na následujícím grafu. 
Grafč. 2 Výběrový soubor (regionální rozložení)

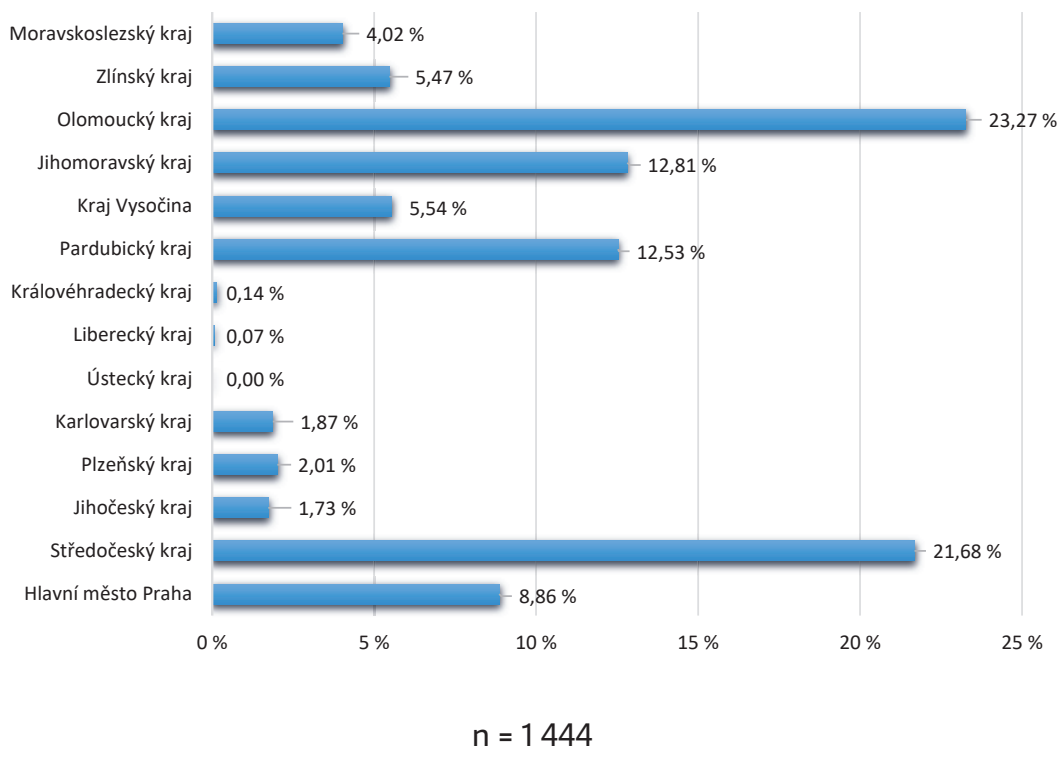

\subsection{Výzkumný nástroj}

Výzkum byl s ohledem na zamýšlené množství respondentů orientován kvantitativně. Při sběru dat bylo použito dotazníkové šetření, které jsme pro přehlednost rozdělili na část zkoumající vztah žáků 2. stupně ZŠ k médiím s důrazem na sociální sítě (17 položek v dotazníku) a část zabývající se vybranými aktuálními problémy mediální výchovy u žáků 2. stupně ZŠ (20 položek v dotazníku). Celkově se tedy dotazník skládá z 37 položek, jež vznikly na základě teoretických poznatků a byly sestaveny takovým způsobem, aby reflektovaly statované cíle a vzniklé problémy.

Pro větší přehlednost si na tomto místě uvedeme podrobnější popis jednotlivých položek v dotazníku. Jak již bylo zmíněno, dotazník jsme si rozdělili na dvě části. První část je tvořena 17 položkami, z nichžje 10 položek uzavřených výběrových, 5 položek otevřených, 1 položka uzavřená výčtová a 1 položka uzavřená dichotomická. Položky lze také rozdělit na: 
- jednu položku³ zjištující, jaké médium používají žáci jako zdroj informací nejčastěji,

- šest položek ${ }^{4}$ zabývajících se tím, jestli si žáci na internetu ověřují pravdivost informací, fotografií a profilů uživatelů sociálních sítí a podle jakých kritérií se rozhodují,

- pět položek ${ }^{5}$ zaměřujících se na to, zda žáky ovlivňují influenceři, které na sociálních sítích sledují,

- pět položek ${ }^{6}$ zabývajících se nenávistnými příspěvky na internetu.

Druhá část dotazníku se skládá z 20 položek (17 položek uzavřených výběrových a 3 položky uzavřené výčtové s výběrem neomezeného počtu odpovědí):

- čtyři položky se zaměřují na schopnost žáků rozeznat dezinformace a hoaxy;

- čtyři položky ${ }^{8}$ se zaměřují na schopnost žáků rozeznat falešné profily na sociálních sítích a falešné fotografie;

- jedna položka9 je kombinací dvou výše zmíněných úloh;

- čtyři položky ${ }^{10}$ se zabývají reklamou z různých hledisek - reklama na sociálních sítích, klamavá reklama, product placement a sexismus v reklamách;

- tři položky ${ }^{11}$ se zaměřují na nenávistné projevy na internetu;

- čtyři položky ${ }^{12}$ se zabývají médii obecně - mediálními stereotypy, veřejnoprávními médii a komunikačním stylem bulváru.

E-mail s popisem výzkumu řešitelky a s internetovým odkazem na elektronický dotazník vytvořený v Google Forms byl rozeslán pomocí dotazníkového systému E-Bezpečí na kontaktní e-mail všech základních škol v České republice, které zřizují 2. stupeň. Soupis adres pořídili členové týmu E-Bezpečí z veřejně dostupných zdrojů, a to $\mathrm{z}$ důvodu realizace předchozích

\footnotetext{
3 Položka 2. části dotazníku č. 1.

4 Položka 2. části dotazníku č. 2, 3, 4, 5, 6, 7.

5 Položka 2. části dotazníku č. 8, 9, 10, 11, 12.

6 Položka 2. části dotazníku č. 13, 14, 15, 16, 17.

7 Položka 1. části dotazníku č. 1, 3, 8, 10.

8 Položka 1. části dotazníku č. 4, 14, 16, 18.

9 Položka l. části dotazníku č. 20.

10 Položka 1. části dotazníku č. 2, 6, 11, 13.

11 Položka 1. části dotazníku č. 7, 15, 17.

12 Položka 1. části dotazníku č. 5, 9, 12, 19.
} 
výzkumných šetření. Bylo na zvážení každé základní školy, zda dotazníky žákům zprostředkuje, tudíž zde zásadní roli hraje náhoda a dobrovolnost základních škol se do výzkumu zapojit. Výzkumník do výběru respondentů tedy nijak nezasahuje.

\section{4 Časový harmonogram výzkumu}

Příprava výzkumu byla zahájena 1. 3. 2020, sběr dat probíhal od 15. 4. 2020 do 15. 6. 2020. Jejich vyhodnocování bylo realizováno v průběhu července a srpna roku 2020.

\subsection{Data a jejich zpracování}

Na tomto místě budeme opět pro přehlednost dělit dotazník na dvě části, protože obě pracují s jiným druhem dat - první část dotazníku pracuje s daty metrickými, zatímco druhá část pracuje s daty nominálními.

\subsubsection{Dotazník - 1. část}

Tato část dotazníku pracuje s daty nominálními. Nejprve byla provedena kategorizace odpovědí. U položek výběrových a dichotomických je počet kategorií dán počtem nabízených odpovědí. Jedná se o položky č. 1, 2, 4, 6, $8,9,11,12,13,15$ a 16.

U položky č. 14, která je výčtová, byly kategorie určeny podle jednotlivých odpovědí. Zároveň tato položka obsahuje odpověd' „jiná“, která dává respondentům možnost vyjádřit se mimo nabízené možnosti. Odpovědi v možnosti „jiná“ budeme na základě společných znaků kategorizovat.

Odpovědi v otevřených položkách (položky č. $3,5,7,10,17$ ) byly náročnější na vyhodnocování, protože jsme museli jednotlivé odpovědi seskládat do kategorií na základě podobnosti. Uvedli jsme také příklady některých autentických odpovědí žáků, které jsou v tomto textu psány kurzívou.

Následoval poslední krok, a tím bylo třídění. Bylo provedeno třídění 1. stupně, tzn. bylo vytvořeno tolik tabulek četností, kolik je položek v dotazníku (tedy 17). Na základě těchto tabulek byly navrženy grafy, na kterých můžeme data sledovat názorněji. 


\subsubsection{Dotazník - 2. část}

Tato část dotazníku zahrnuje praktické ukázky jednotlivých aktuálních problémů (podrobněji se na jednotlivé položky podíváme ve třetí kapitole monografie) a je realizována formou kvízu. Tuto formu jsme zvolili z toho důvodu, že s její pomocí můžeme sledované jevy zkoumat co nejefektivněji právě s využitím praktických ukázek.

Správné odpovědi v uzavřených výběrových položkách jsou hodnoceny jedním bodem (jedná se celkově o 17 položek). Položky výčtové s neomezeným výběrem odpovědí (celkem tři položky) jsou hodnoceny dvěma způsoby, podle kterých se tato část dotazníku bude dělit na variantu A (hodnocena přísněji) a variantu B (hodnocena mírněji). Zároveň žáci nejsou informováni o tom, kolik správných odpovědí mají vybrat, abychom zabránili hádání správných odpovědí. Maximální počet bodů, který lze v obou variantách dotazníku dosáhnout, je 20.

Ve variantě A hodnotíme výčtové položky podle kritéria „všechno, anebo nic“. Podle tohoto přístupu přidělíme 1 bod pouze v případě, že žák označí všechny správné odpovědi (v každé z položek s výběrem více odpovědí jsou vždy dvě správné odpovědi). V jiném případě bude mít žák o bodů, a to i kdyby označil jednu správnou odpověd' ze dvou.

Ve variantě B hodnotíme výčtové položky tak, že přidělíme 1 „pomocný “ bod za každou označenou správnou odpověd' a 1 pomocný bod za každou neoznačenou nesprávnou odpověd'. Výsledný součet pomocných bodů potom dělíme počtem nabídek v položce. Maximální bodový zisk v položce je tedy jeden bod. Tento způsob hodnocení je mírnější než u varianty A, protože žáci dostávají body i za jednu správnou odpověd'.

Výsledky varianty B nás zajímají pouze z hlediska komparace s variantou A, jelikož jsou jednotlivé správné možnosti odpovědí ve výčtových položkách nastaveny tak, že spolu velmi úzce souvisejí a předpokládá se, že pokud žák určí jednu správnou odpověd', měl by logicky zvolit také druhou správnou odpověd'. Zároveň je pro nás jednodušší a přehlednější pracovat pouze s jednou variantou dotazníku.

Následně bylo provedeno třídění 1. stupně, tzn., že bylo vytvořeno tolik tabulek četností, kolik je položek v dotazníku (tedy 20). Na základě těchto tabulek byly vytvořeny grafy zachycující u každé položky počet správných a chybných odpovědí.

Jelikož výsledná data byla data metrická (pracujeme s počtem dosažených bodů), byl určen aritmetický průměr a směrodatná odchylka.

Pro grafické znázornění rozdílu počtu bodů mezi dívkami a chlapci a mezi jednotlivými třídami byly použity krabicové grafy. 


\section{3 \\ Výsledky výzkumu}

V této kapitole shrneme veškerá získaná data. Jak bylo uvedeno v předchozí kapitole, dotazník pro větší přehlednost dělíme na dvě části, přičemž každou položku z dotazníku okomentujeme a připojíme k ní patřičný graf.

\subsection{Dotazník - 1. část}

V první části dotazníku se zaměřujeme na to, jaké médium používají žáci jako zdroj informací nejčastěji, jestli si žáci na internetu ověřují pravdivost informací, fotografií a profilů uživatelů sociálních sítí a podle jakých kritérií se rozhodují, zda žáky ovlivňují influenceři, které na sociálních sítích sledují, a jakou mají zkušenost s nenávistnými příspěvky na internetu.

Výše zmíněné koresponduje $s$ výzkumnými otázkami, které si v této části dotazníku klademe. Pro připomenutí si je zde uvedeme:

- Jaký zdroj informací používají žáci 2. stupně ZŠ nejčastěji?

- Ověřují si žáci 2. stupně ZŠ pravdivost informací, fotografií a profilů uživatelů sociálních sítí na internetu a podle jakých kritérií se rozhodují?

- Ovlivňují žáky 2. stupně ZŠ influenceři, které na sociálních sítích sledují?

- Chtějí si žáci 2. stupně ZŠ zakoupit výrobek, který propaguje jejich oblíbený influencer na sociálních sítích? Domnívají se, že je influencer přesvědčen o kvalitě tohoto výrobku?

- Z jakého důvodu, dle mínění žáků 2. stupně ZŠ, influencer daný výrobek propaguje? 
- Napodobují žáci 2. stupně ZŠ stravovací návyky oblíbeného influencera, kterého na sociálních sítích sledují?

- Drželi žáci 2. stupně ZŠ dietu nebo dodržovali cvičební režim, aby se podobali svému oblíbenému influencerovi, kterého sledují na sociálních sítích?

- Píšou žáci 2. stupně ZŠ na internet nenávistné příspěvky? Pokud ano, na koho tyto příspěvky útočí?

- Ovlivňuje četba nenávistných příspěvků vztah žáků 2. stupně ZŠ $\mathrm{k}$ dané skupině (etnické, náboženské apod.)?

- Byli žáci 2. stupně ZŠ někdy obětí nenávistných příspěvků na internetu? Pokud ano, čeho se tyto př́spěvky týkaly?

\subsubsection{Zdroj informací, který žáci používají nejčastěji}

V úvodu této části dotazníku nás zajímalo, jaký zdroj používají žáci při hledání informací nejčastěji. Naším předpokladem bylo, že tím nejpoužívanějším zdrojem bude internet, a odpovědi žáků tento náš předpoklad naplnily.

Graf č.3 Nejpoužívanější zdroj informací

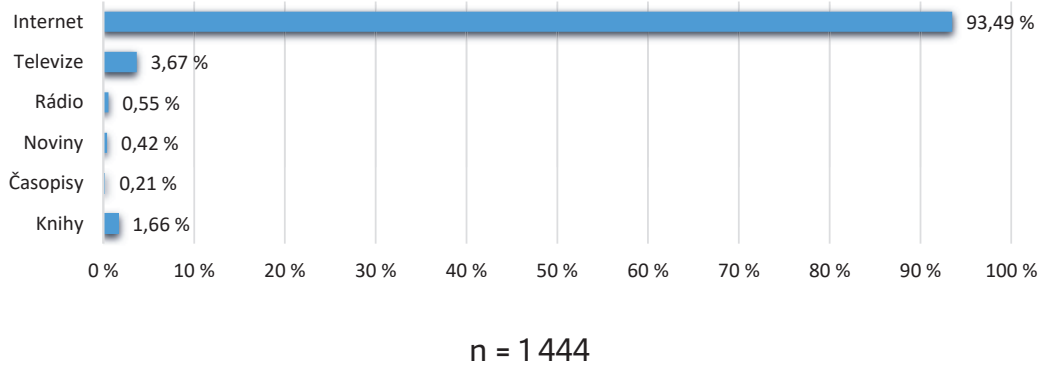

Naprostá většina žáků (93,49 \%) jako zdroj informací používá internet. Toto zjištění nám potvrzuje, že zaměření této publikace na aktuální problémy mediální výchovy spojené s využíváním moderních informačních a komunikačních technologií, mezi něž internet samozřejmě spadá, bylo vhodně zvoleno a může být přínosné. Bohužel většina českých učebnic mediální výchovy se orientuje na média jako rádio, noviny, časopisy, televize a knihy, a ty, jak můžeme vidět $v$ grafu, jsou žáky používány minimálně. $V$ tomto směru bychom chtěli přispět k otevření diskuze o aktuálnosti a možné úpravě těchto učebnic, aby odpovídaly současným trendům a potřebám žáků. 


\subsubsection{Ověřování pravdivosti informací a fotografií na internetu}

V dalších položkách jsme se zabývali tím, zda si žáci ověřují pravdivost informací a fotografií, které se nacházejí na internetu. Zároveň jsme pomocí otevřených položek zjištovali, podle jakých kritérií se žáci rozhodují, jestli je daná informace či fotografie pravdivá, nebo nepravdivá.

Graf č. 4 Ověřování pravdivosti informací a fotografií na internetu

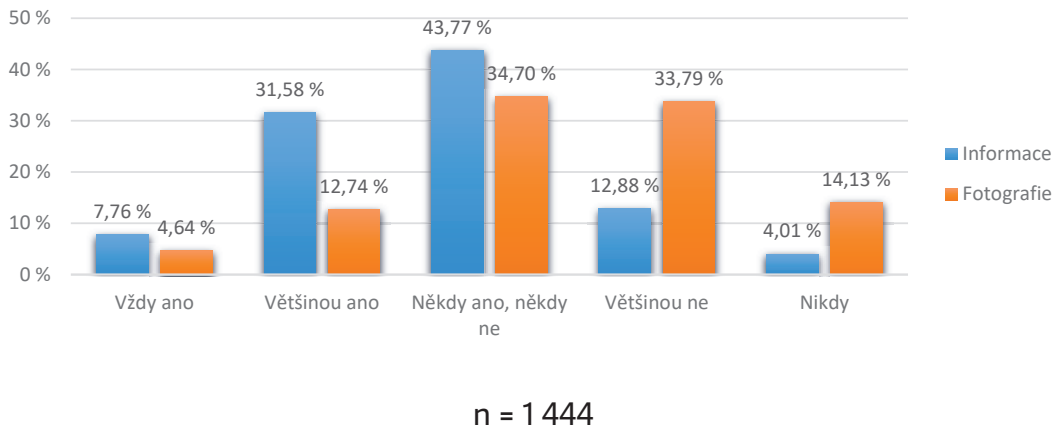

Téměř polovina žáků (43,77 \%) si pravdivost informací na internetu někdy ověřuje a někdy neověřuje. Rovněž převažuje počet žáků, kteří si informace vždy ověřuji ( 7,76 \%) či většinou ověřuji (31,58 \%) nad žáky, kteří si informace nikdy neověřují (4,01 \%) nebo většinou neověřují (12,88 \%). Odlišné tendence můžeme pozorovat u ověřování pravdivostí fotografií, kde naopak převažují žáci, kteří si fotografie většinou neověřují (33,79 \%) a nikdy neověřují (14,13 \%), nad žáky, kteří fotografie většinou ověřují (12,74 \%) a vždy ověřují (4,64 \%). Může to být dáno tím, že když vidíme něco na fotografii či videu, máme sklony si myslet, že je to automaticky skutečné. Právě těchto sklonů tvůrci fake news využívají. U informací si dáváme větší pozor, protože u nich chybí vizuální smyslová složka. Na upravené fotografie však nemusíme narazit jen na dezinformačních webech, ale i na běžných sociálních sítích, kde si lidé mohou své fotografie různě vylepšovat, aby vypadali lépe a krásněji. V ostatních uživatelích to pak může vyvolávat pocity nedostatečnosti, protože si neuvědomují, že daná fotografie může být upravená.

Jedním $\mathrm{z}$ dílčích cílů mediální výchovy je vést žáky $\mathrm{k}$ tomu, aby si informace a fotografie, na které na internetu narazí, ověřovali. Proto bychom v tomto smyslu měli usilovat o to, aby se procento žáků, kteří jejich pravdivost ověřují, zvyšovalo. Avšak abychom tohoto cíle mohli dosáhnout, měli bychom žáky naučit, podle jakých znaků pravdivou či nepravdivou infor- 
maci nebo fotografii poznají, a dlouhodobě rozvíjet jejich kritické myšlení napříč všemi předměty.

\section{Podle jakých kritérií se žáci rozhoduji, zda je nějaká informace nebo fotografie na internetu pravdivá}

V rámci výzkumu dostali žáci možnost vyjádřit sek tomu, podlejakých kritérií se rozhodují,jestli jsou nějaké informace či fotografie, vyskytující se na internetu, pravdivé. Jednotlivé odpovědi jsme na základě podobnosti rozdělili do kategoriía ty, které se objevovaly nejčastěji,jsme zaznačili do následující tabulky. K otázce, podle jakých kritérií si žáci ověřují informace, se nevyjádřilo 25,21 \% z nich. U fotografií bylo žáků, kteří neodpověděli, 31,68 \%. Odpovědi, které se objevovaly jen zř́́dka nebo s otázkou nesouvisely,jsme do tabulek nezaznačili.

\section{A. INFORMACE}

Tab. č. 1 Podle jakých kritérií se žáci rozhodují, zda je nějaká informace na internetu pravdivá?

\begin{tabular}{|c|c|c|}
\hline & $\begin{array}{l}\text { Absolutní } \\
\text { četnost }\end{array}$ & $\begin{array}{c}\text { Relativní } \\
\text { četnost }\end{array}$ \\
\hline Ověřím si informaci z více zdrojů. & 444 & $30,75 \%$ \\
\hline $\begin{array}{l}\text { Rozhodnu se podle toho, na jakém webu se informace } \\
\text { nachází/kdo je autorem. }\end{array}$ & 216 & $14,96 \%$ \\
\hline Použivám (selský) rozum/logiku. & 165 & $11,43 \%$ \\
\hline $\begin{array}{l}\text { Rozhodnu se podle obsahu informace/jakým jazykem } \\
\text { je psána. }\end{array}$ & 112 & $7,76 \%$ \\
\hline Zeptám se rodičů. & 79 & $5,47 \%$ \\
\hline Rozhodnu se podle komentářů pod informací. & 21 & $1,45 \%$ \\
\hline
\end{tabular}

Žáci si nejčastěji pravdivost určité informace, vyskytující se na internetu, ověřují tak, že si vyhledají více zdrojů, které o dané informaci pojednávají. Pokud se tyto zdroje ve svých závěrech shodují, vyhodnotí žáci danou informaci jako pravdivou. Dalším velmi častým kritériem bylo místo (web), kde se daná informace vyskytuje, a také její autor, přičemž žáci kladli důraz na to, že se informace musí vyskytovat na ověřených webových stránkách, aby byla 
vnímána jako důvěryhodná. Třetím nejčastějším kritériem byl zdravý selský rozum či logické uvažování, kdy žáci vycházejí z přesvědčení, že nepravdivou informaci by s jejich pomocí poznali. Avšak selský rozum je ovlivněn prostředím, ve kterém žijeme, a má sklon ke zjednodušování, dogmatismu a schematismu, protože není podložen kritickým myšlením. Navíc naprosto selhává při hodnocení situací či jevů, se kterými nemáme zkušenosti. Z tohoto hlediska může tedy kritérium selského rozumu být problematické. Níže uvádíme některé z ukázek odpovědí žáků (záznamy žáků neprošly jazykovou úpravou):

- Podle toho jak vypadá web na kterém jsou informace uvedeny

- podle toho co o té dané věci vím podle toho usoudím jestli je pravdivá nebo ne a nebo se zeptám rodičů

- Když to potvrdí víc lidí a všechno si ověřim.

- jestli dává logiku.

- Zeptám se rodičů nebo sourozenců

- Jestli tam nejsou gramatické chyby, přehršel caps locku a jestli není zbytečně nenávistná.

- zapojím svoje kritické myšlení

- Vyhledám si další varianty nebo hledám na oficiálních stránkách

- kontrola z knih nebo jiných webů

- Pokud je na více stránkách stejný údaj, je nejspíše pravdivý.

- není napsaná jen na jednom webu

- Pokud je na více stránkách stejná, je pro mě pravdivá. Pokud hledám na stránce, kterou mám ověřenou, informace je pro mě též pravdivá.

- Na jakých stránkách je, gramatické chyby a pokud jsem to už někde viděl, ale je to jinak

- vždy si tuto zprávu oveř́ím tak že si řeknu jestli tato zpráva by mohla být realita

- Vyhledám jí na více stránkách a zkontroluji jestli se informace shoduje.

- Internet nikdy nelže!!!!!!!!

- jak je to napsané

- podle zdroje, podle zdravého rozumu - konzultace s rodiči

- ověřuji si ji v knihách, na jiných webových stránkách, v novinách, časopisech..

- Nečtu zprávy, hraji jen hry.

- Pokud je odzdrojována např. zdroj:web PČR, Kvalita zpráv-spisovnost, gramatika atd.

- Podle mích znalostí

- podle mozku

- Jiné stránky nebo comenty 
- podle selského rozumu a wikipedie

- vyhledám si jíjinde o ověřím pravdivost

- Podle webu na kterým se správa nachází a hledám jestli se o tom ještě někde píše.

- Podle ověřeného zdroje informace (např. ČTK, Český rozhlas, Česká Televize)

- Pokud mi dává smysl.

- Hledám info na více webech

- Snažím se najít více takových webů, které obsahují stejnou informaci.

- Je na více zdrojích a dává logiku.

- oveř̌ím fakta z několika zdrojů. Pokud se neshodují, použiji nejvěrohodnější médium které znám.

- Souvislosti s aktuálním děním ve světě,jméno autora

- Většinou podle toho kolik lidí o tom píše a kde všude se o tom píše.

\section{B. FOTOGRAFIE}

Tab.č. 2 Podle jakých kritérií se žáci rozhodují, zda je nějaká fotografie na internetu pravdivá?

\begin{tabular}{|c|c|c|}
\hline & $\begin{array}{l}\text { Absolutní } \\
\text { četnost }\end{array}$ & $\begin{array}{l}\text { Relativní } \\
\text { četnost }\end{array}$ \\
\hline $\begin{array}{l}\text { Podle toho, jak fotografie vypadá (zkreslená, úprava } \\
\text { ve Photoshopu apod.). }\end{array}$ & 310 & $21,47 \%$ \\
\hline $\begin{array}{l}\text { Podle toho, jestli je reálná (zobrazuje skutečný } \\
\text { objekt). }\end{array}$ & 97 & $6,71 \%$ \\
\hline Používám (selský) rozum/logiku. & 87 & $6,02 \%$ \\
\hline Porovnám ji s jinou fotografií nebo více zdroji. & 85 & $5,88 \%$ \\
\hline Vyhledám ji pomocí vyhledávače „Google obrázky“. & 61 & $4,22 \%$ \\
\hline Zjistím si původní zdroj fotografie. & 46 & $3,19 \%$ \\
\hline Zjistím, kdo je autorem fotografie. & 26 & $1,80 \%$ \\
\hline Zeptám se rodičů. & 16 & $1,11 \%$ \\
\hline
\end{tabular}


Nejčastěji žáci pravdivost fotografie, vyskytující se na internetu, určují podle jejího vzhledu, a to zejména podle toho, jestli na ní nejsou patrné úpravy pomocí Photoshopu (oříznutí, stíny, zkreslení, zvlnění apod.). Dalším rozhodujícím kritériem je, jestli je to, co fotografie znázorňuje, reálné a můžeme se s tím opravdu setkat ve skutečném životě. Třetí nejčastějším kritériem je, stejně jako u otázky ohledně pravdivosti informací, zdravý selský rozum a logika. O problematičnosti tohoto kritéria jsme již informovali výše. Jako velmi pozitivní hodnotíme to, že žáci znají možnost vyhledat si fotografii pomocí vyhledávače Google. Ten nám totiž ukáže, kde všude se daná fotografie vyskytuje, př́ipadně odkud byla stažená. Tato dovednost se hodí také při určování falešných profilů uživatelů na sociálních sítích, které si rozebereme v další podkapitole. Níže uvádíme některé z ukázek odpovědí žáků (záznamy žáků neprošly jazykovou úpravou):

- Podle toho jestli je reálná..

- Podle toho, jestli je to nějaká blbost nebo ne.

- Podle kvality a zpracování dané fotky.

- Pokud nejde poznat manipulace s fotkou

- Já takovéhle věci moc neřeším prostě jestli to vypadá pěkně tak to olajkuju a jedu dál.

- Zamyslím se jestli to může být vůbec reálné, a poté si např. vyhledali dalši fotografie stejné věci, člověka apod.

- jde vidět když je opravova a na zakladě informací k fotce

- Jestli je ta situace realni a vím že se to může stát.

- Poznám co je photoshop a co ne

- porovnám s jinou nebo se zeptám rodičů

- Většinou se nijak nerozhoduji, když vidím nějakou fotku, podívám se jen, jestli je nějak výrazně upravená, nebo vypadá opravdu věrohodně.

- umím rozeznat jestli to je upravená fotografie

- Podívám se na autora a na jeho profil a potom hledám jestli to nestáhnul od někoho

- Hodim ji do googlu a nebo se zaměřuju na chyby v fotce.

- Vkládání fotek do googlu a ten zobrazí stejné či dané fotografie.

- Pokud fotografii uvidím na soc. sítích podívám se na internet jestli není $z$ někama stáhlá

- Dívám se na detaily a pokud vidím špatně ořezanou fotku tak vím, a nebo si to začnu vyhledávat na internetu.

- Pokud je u obrázků na soc. síti text napsán capslk jedna se nejpravděpodobnější o hoax. Tím se řílím.

- Jestli se neobjevuje na dalších sociálních sítích. 
- podle toho že tam nevidím třeba špatně ořezané části z jiných fotografí, zda je tam správně stín, z jakého portálu to je a všímám si i maličkostí... např. okolí, jiný odstín na kousku ruky

- Mě moc takové věci nezajímají, takže si většinou neověr̆uji, jestli je fotografie pravdivá.. Internet mám jen kvůli mým reálným přátelům, abychom se mohly i v této době nějak vídat (videohovory), nebo si psát.

- přirozený instinkt umělce a částečná znalost Photoshopu

- Levým tlačítkem kliknu na obrázek a rozkliknu odkaz „Vyhledat obrázek pomocí vyhledávače Google“

\subsubsection{Ověřování pravdivosti profilů uživatelů na sociálních sítích}

Ve výzkumu jsme se zabývali také tím, zda si žáci ověřují pravdivost profilů uživatelů na sociálních sítích. Víme, že někteří uživatelé na sociálních sítích mohou vystupovat pod falešnou identitou s cílem manipulovat ostatními uživateli nebo jim dokonce uškodit. Zároveň jsme pomocí otevřené položky zjištovali, podle jakých kritérií se žáci rozhodují, jestli je nějaký profil pravdivý, nebo nepravdivý.

Graf č.5 Ověřování pravdivosti profilů uživatelů na sociálních sítích

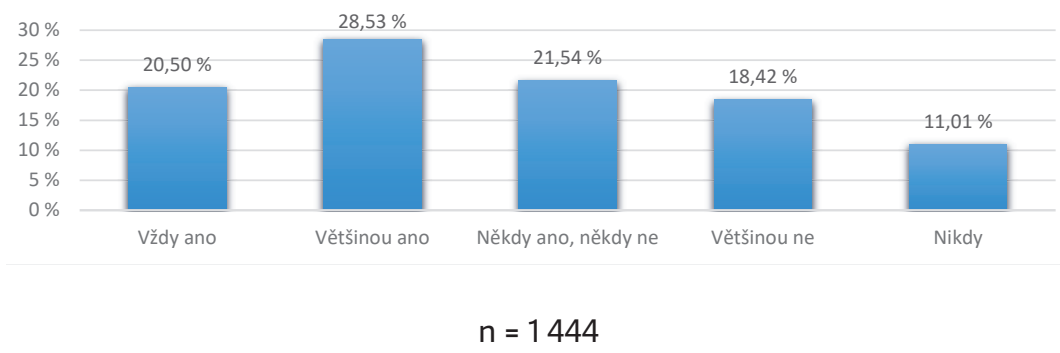

Žáci nejčastěji uvádějí, že pravdivost profilů uživatelů na sociálních sítích většinou ověřují (28,53 \%). Vždy profily ověřuje 20,50 \% žáků a někdy profily ověřuje a někdy neověřuje 21,54 \% žáků. Téměř pětina žáků (18,42 \%) profily většinou neověřuje. Pravdivost profilů si vůbec neověřuje 11,01 \% žáků. 
Podle jakých kritérii se žáci rozhodují, zda je profil

\section{uživatele na sociálních sítích pravdivý}

V rámci výzkumu dostali žáci možnost vyjádřit se $\mathrm{k}$ tomu, podle jakých kritérií se rozhodují, zda je profil uživatele na sociálních sítích pravdivý. Jednotlivé odpovědi jsme na základě podobnosti rozdělili do kategorií a ty, které se objevovaly nejčastěji, jsme zaznačili do následující tabulky. K otázce se nevyjádřilo 30,40 \% žáků. Odpovědi, které se objevovaly jen zřídka nebo s otázkou nesouvisely, jsme do tabulek nezaznačili.

Tab. č.3 Podle jakých kritérií se žáci rozhodují, zda je profil uživatele na sociálních sítích pravdivý?

\begin{tabular}{|c|c|c|}
\hline & $\begin{array}{l}\text { Absolutní } \\
\text { četnost }\end{array}$ & $\begin{array}{c}\text { Relativní } \\
\text { četnost }\end{array}$ \\
\hline Podle fotografií. & 218 & $15,10 \%$ \\
\hline Podle příspěvků na profilu. & 192 & $13,30 \%$ \\
\hline Podle počtu sledujících/přátel. & 191 & $13,23 \%$ \\
\hline Podle toho, jestli toho člověka znám. & 128 & $8,86 \%$ \\
\hline Podle toho, jestli má ověřující symbol. & 74 & $5,12 \%$ \\
\hline Použivám (selský) rozum/logiku. & 51 & $3,53 \%$ \\
\hline Zeptám se rodičủ/přátel. & 34 & $2,35 \%$ \\
\hline Podle jména. & 33 & $2,28 \%$ \\
\hline Vyhledám jej pomocí vyhledávače „Google obrázky“. & 28 & $1,94 \%$ \\
\hline Podle data založení profilu. & 23 & $1,60 \%$ \\
\hline Podle stylu psaní příspěvků/zpráv. & 22 & $1,52 \%$ \\
\hline
\end{tabular}


Nejčastěji se žáci rozhodují podle fotografií a příspěvků, které se na profilech objevují. Avšak toto kritérium nemusí být úplně správné, protože některé falešné profily vypadají velmi věrohodně, jelikož je jejich autoři tvoří i několik měsíců. Mohou si např́klad vyhledat profil nějakého neznámého zahraničního influencera a veškeré jeho příspěvky a fotografie kopírovat do svého falešného profilu. Rozeznat tedy falešný profil pomocí těchto kritérií nemusí být tak jednoduché. Dále se žáci rozhodují podle toho, jestli danou osobu na profilu znají, přičemž pokud tuto osobu neznají, tak s ní vůbec nenavazují kontakt nebo se zeptají někoho jiného, zda tuto osobu nezná. U účtů veřejně známých osobností se pak žáci o jejich pravdivosti rozhodují pomocí ověřujícího symbolu. Dalším nejčastějším kritériem je zdravý selský rozum, o jehož úskalí jsme psali výše. Žáci se také rozhodují podle jména daného profilu, podle vyhledávače "Google obrázky“ (viz výše), podle data založení a stylu psaní zpráv či příspěvků. Níže uvádíme některé z ukázek odpovědí žáků (záznamy žáků neprošly jazykovou úpravou):

- Píšu si jen s kamarádkama, které znám.

- Když ho sledují moji kamarádi a vím že se s ním znají

- Podívám se kdo to je, jestli ho vůbec znám, a pokud se ten dotyčný vydává za někoho, koho znám tak ten účet nahlásím a blokuju.

- jde to vidět když si vás přidá nějaká modelka tak to asi logicky bude nějaký $50 t i$ letý muž

- podle fotek (kdyz uz jsem je videla u nekoho, kdo je tam ma dele, profil je falesny, atd)

- Když profil daného člověka znám, napiši mu, nebo mu přijmu žádost o přátelství. Pokud ho neznám, nějak víc to neřeším, pokud mě nějak neuráží nebo mě zprávou neoslovil.

- Jak dlouho je založení

- Podle fotek a videochatu

- Dívám se a nejsem blbej.

- Podle stylu - například vím že můj kamarád nebude hrát fotbal.....

- Když tam jsou fotky, které má ze svého osobního života.

- Prohlédnu si, co sleduje za lidi a jací lidé ho sledují. Pak se většinou dívám na počet fotek a hledám si jestli nejsou stažené $z$ internetu.

- Na sociálních sítích mám jenom dobré prátele se kterými si pak o tom promluvim osobně

- nemám důvod si myslet, že to není pravdivý profil

- Pokud toho člověka znám osobně tak se ho zeptám, pokud se ale jedná o účet nějaké celebritytak se např na instagramu podívám na jeho den 
(jestli tam vystupuje) a nebo se podívám u jeho jména účtu na modry odznacek

- Zkopíruji a vložím obrázky z profilu do Google pictures, a vyhledám i jiné profily, pokud by to byl slavný člověk, pravý profil má více followerů.

- Na Instagramu je u profilu modrá fajfka

- Jestli fotce odpovídá věk nebo pohlaví

- Je mi to jedno, pokud mě nekontaktuje. Pokud ano, podívám se na jeho/ její profil a z mého vlastního presvědčení usoudím jestli je, nebo není pravdiví. Pokud ano, odepíšu, pokud není, tak ho ignoruji. A pokud má $v$ profilu fotky člověka, které neznám a přijde mi, že je to nějaký pedofil nebo násilník tak si ho i zablokuji.

- 1. Kolik má followerů. 2. Jestli ve jménu není něco jinak.

- Např. Jestli je to nějaká známá osobnost a má jenom 50 sledujících, tak bude nejspíš falešný.

- Kolik ma sledujicich, jestli ho sleduje vic jak z lidi, co znam, jestli nepostnul vsechny fotky ve stejny cas za sebou.....

- videohovor, fotka obličeje s určitým nápisem do iminuty

- Nepoužívám sociální sítě, kde by bylo toto potřeba (Facebook atd.). Nejčastěji používám intagram, kde jsou falešné profily bud' jednoduše rozeznatelné, nebo se knim člověk ani nedostane, pokud je př́mo nevyhledává. Pravdivé profily jsou často verifikované speciálním odznáčkem (u slavnějších osob). U kamarádů jsem si jejich pravdivostí jistý..

- Více fotek. Pokud má člověk na svém profilu pouze jednu fotku sebe je jasné, že ji vzal z internetu a nenašel žádnou jinou fotku, proto má jen 1. Dále, že sleduje uživatele mého věku a nikdo s ním není v přátelství.

- Mezi "fake" profily patří hlavně profily, kteří mají třeba jen 1-3 fotky nějaké pěkné holky či hezkého kluka. Poté existuje možnost si fotografii jaksi stáhnout a dát ji do vyhledávání, ale s tímto neumím :D

- Rozmyslím si jestli by ten daný člověk dával na svůj profil zrovna tyto př́spěvky.

- Hodně prozradí bio, profilová fotka. Někdy se to pozná i podle sledujících (z jaké země pochází, když má člověk většinu sledujících z Indie, může se jednat o fake profil).

- Sleduji pouze lidi který znám, a mám soukromí účet takže ho povoluju pouze kamarádům... A nebo napíšu kamarádům, pokud ho neznají tak neodpovídám a zablokuju ho a pokud ho znaji tak but odpovím nebo ne. 


\subsubsection{Vliv influencerů na žáky}

V následující podkapitole se zaměřujeme na to, jaký mají influenceři vliv na žáky. Zajímalo nás především to, jestli mají žáci tendenci napodobovat životní styl svých oblíbených influencerů a do jaké míry na žáky působí reklama, kterou na sociálních sítích influenceři vytvářejí.

\section{Influenceři a reklama na sociálních sítích}

V rámci výzkumu jsme zjištovali, zda jsou žáci ovlivněni reklamou na určité výrobky, které jejich oblíbený influencer na svých sociálních sítích propaguje. V současné době se velmi často setkáváme s tím, že influenceři mohou mít z reklam na svých sociálních sítích (Instagram, Facebook, TikTok apod.) určitý zisk, který jim může pokrýt jejich životní náklady. Marketingové agentury jsou si zároveň vědomy velké propagační síly influencerů, a proto tuto formu propagace svých výrobků využívají stále častěji. $\mathrm{Na}$ následujícím grafu můžeme vidět odpovědi žáků, zda by si koupili výrobek, který jejich oblíbený influencer propaguje (tzn. fotí se s ním, píše o něm př́spěvky apod.).

Graf č. 6 Ochota koupit si výrobek propagovaný oblíbeným influencerem

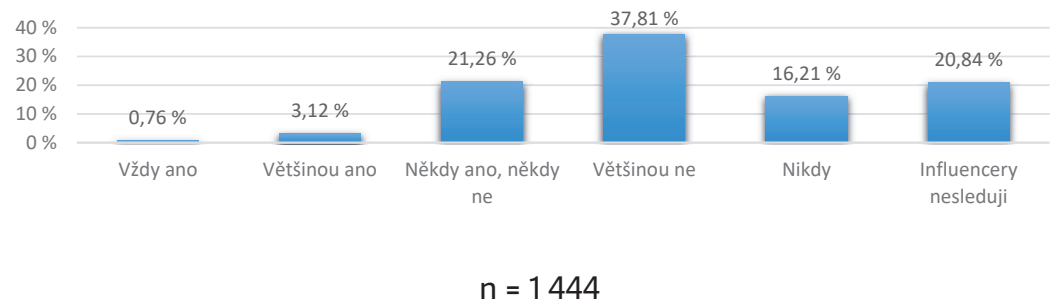

Více než třetina žáků (37,81 \%) uvádí, že si výrobky propagované influencery většinou nekoupí. Někdy si výrobky zakoupí 21,26 \% žáků a nikdy si výrobky nezakoupí 16,21 \% žáků. Relativně malé procento žáků si výrobek většinou zakoupí (3,12 \%) a vždy zakoupí (0,76 \%). Poměrně vysoké je i procento žáků, kteří influencery nesledují (20,84 \%). Na základě těchto dat lze tvrdit, že žáci jsou reklamou od influencerů ovlivněni velmi zřídka. Za zamyšlení stojí, jestli by se odpovědi žáků lišily, pokud by měli stálý př́ijem financí, mohli s nimi svobodně nakládat a nebyli odkázáni na kapesné od rodičů, jak je tomu v tomto školním věku zvykem.

Dále nás v rámci výzkumu zajímalo mínění žáků o tom, jestli jsou influenceři upřímní v souvislosti s propagovaným výrobkem, nakolik mu dů- 
věřují a do jaké míry jsou přesvědčeni o jeho kvalitě. Jsme si vědomi, že tato položka je velmi obecná a netýká se určitého konkrétního influencera, ale influencerů celkově. Zajímal nás totiž globální pohled žáků na propagaci výrobků na sociálních sítích. Odpovědi žáků jsou zachyceny v následujícím grafu.

Graf č.7 Přesvědčení influencerů o kvalitě propagovaného výrobku z pohledu žáků

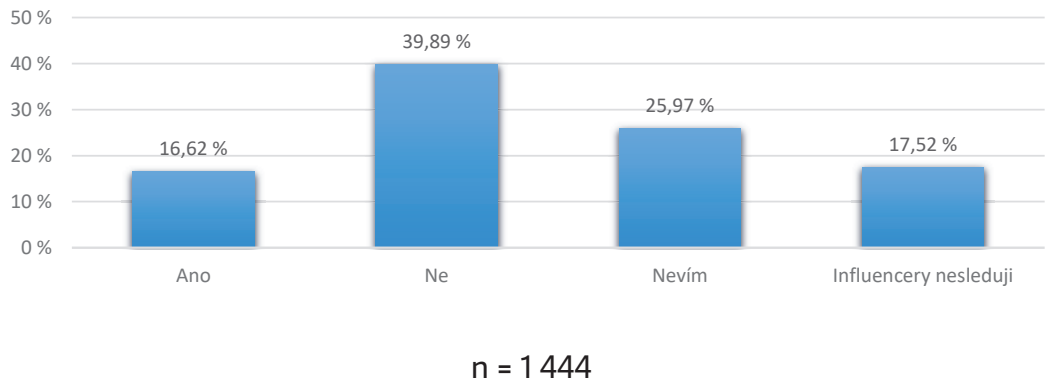

Poměrně malé procento žáků (16,62 \%) uvedlo, že influenceři jsou při propagaci výrobků přesvědčeni o jejich kvalitě. Více než třetina žáků $(39,89 \%)$ si myslí, že influenceři o kvalitě propagovaného výrobku přesvědčeni nejsou. Žáků, kteří neví, zda jsou influenceři přesvědčeni o kvalitě propagovaného výrobku, je $25,97 \%$ a influencery vůbec nesleduje $17,52 \%$ žáků.

V následující tabulce jsou zachyceny odpovědi žáků na otevřenou položku, která zjištovala, z jakého důvodu, dle mínění žáků, influenceři daný výrobek propagují. K otázce se nevyjádřilo 19,88 \% žáků. Odpovědi, které se objevovaly jen zrrídka nebo s otázkou nesouvisely, jsme do tabulek nezaznačili.

Tab. č. 4 Názory žáků na to, proč influenceři propagují výrobky na svých sociálních sítích

\begin{tabular}{|l|c|c|}
\hline & $\begin{array}{c}\text { Absolutní } \\
\text { četnost }\end{array}$ & $\begin{array}{c}\text { Relativní } \\
\text { četnost }\end{array}$ \\
\hline Protože jim jde o peníze. & 775 & $53,67 \%$ \\
\hline $\begin{array}{l}\text { Protože chtějí peníze nebo jsou s výrobkem } \\
\text { spokojeni (záleží na influencerovi). }\end{array}$ & 182 & $12,60 \%$ \\
\hline
\end{tabular}


Protože nám chtějí doporučit výrobek, se kterým jsou spokojeni.

$$
n=1444
$$

Více než polovina žáků (53,67 \%) se domnívá, že influenceři určité výrobky propagují jen kvůli finančnímu zisku. Někteří žáci (12,60 \%) dále uvádí, že cílem influencerů není jen finanční zisk, ale také potřeba doporučit svým sledujícím určitý výrobek, se kterým mají dobrou osobní zkušenost, přičemž záleží na každém influencerovi, jaké má priority. V této souvislosti se často objevovala odpověd', že na sociálních sítích se setkáváme se dvěma typy influencerů - s těmi, co výrobku skutečně věří, a s těmi, kterým jde jen o peníze. Malé procento žáků (3,46\%) si myslí, že influenceři si propagací určitých výrobků chtějí zvýšit sledovanost, a 2,08 \% žáků je přesvědčeno, že jedinou motivací influencerů je, že dostanou daný výrobek zdarma. Pouhých 1,87 \% žáků se domnívá, že pokud influencer nějaký výrobek propaguje, dělá to $\mathrm{z}$ toho důvodu, že je s ním skutečně spokojený a nejde mu o finanční zisk. Opravdu nízké procento žáků (0,90 \%) uvádí, že influencerům jde především o to podpořit a zviditelnit daného obchodníka či firmu. Níže jsou ukázky některých odpovědí žáků (záznamy žáků neprošly jazykovou úpravou):

- Z důvodu financí a popularity

- PRACHY!!!

- chtěj to vyskoušet a myslím si že většinou říkají opravdu svuj názor i kdyz je negativní

- Důvodů je více. Například že chtějí zaplatit, a nebo jim daná věc vyhovuje a chtějíji doporučit ostatním.

- Myslím si, že většina $z$ nich to nedělá na základě jejich osobních zkušeností, ale jenom kvůli tomu, aby z toho měli peníze. Samozřejmě to neplatí pro všechny.

- Z youtobu, insagramu a dalších se inflenceři jen tak neuživý a proto propagují výrobky různých firem, kteréjim poté dají nějakou částku.

- Jsou to zaprodání ehm ehm

- Kvůli penězím. Často ten výrobek s němi ani nesouvisí. 
- Co to je za otázku samozřejmě, že pro peníze, vy si snad myslíte snad že mám negativní IQ.

- Finanční kompenzace za to, že ze sebe dělá idiota před každým, kdo zdravě přemýšlí a není úplně naivní. Popř́padě v některých, dle mého názoru vzácných, př́padech protože cítí psychickou satisfakci z oklamání velkého množství lidí, které vede k případnému způsobení škody, za níž jsou ze z legislativního hlediska zodpovědni sami oklamaní.

- Sleduji zahraniční youtube. Jde o daného člověka, ale velmi často jsou propagovány produkty, které „influencerovi“ dobře zaplatí a daný „influencer"s nimi nemá nějaký výhradní problém. Proto si myslím, že o kvalitu výrobku jde jenom minimálně.

- Někteří přijímají spolupráce pouze po vyzkoušení výrobku/služby, nebo „rozhovoru“ s publikem (např. známější streameři z platformy Twitch často dostávají nabídky od vývojár̆ủ her, kdy se třeba 2 živé vysílání (každé plus mínus 8 hodin) věnuje jejich hře a následně za to dostane zaplaceno. Předtím, než spolupráci přijme, se o ní zmíní na streamu a zeptá se diváků, zda by je zajímala ta hra, nebo ji má odmítnout.

- Protože ty výrobky dostanou zdarma a ta daná firma jim napíše aby s tím udělali toto a tamto.

- Záleží podle toho jakého influencera sledujeme, někteří to dělají jen kvůli penězům, ale takové lidi nepodporuji a nesleduji. Ti kteří propagujou nějakou věc měli by jsme ji na něm vidět víckrát, aby jsme se ujistili, že tento výrobek opravdu použivá.

- Dělají z toho reklamu a mají z toho peníze. Štve mě to, když neoznačí placenou propagaci

- Mají z toho provizi, peníze nazpět, třeba affilate marketing, někdo sdílí odkaz, a když si někdo přes odkaz danou věc koupí influencer dostane nějaké peníze od obchodu za propagaci.

- Hodně influencerů výrobky propagují jenom kvůli penězům, které propagováním získají. Často kvůli tomu dané výrobky nemusí být tak dobré, jak je influenceři prezentují.

- Peníze stojí za vším, takže určitě i tady.

- dostavaji penize a nebo chteji jen dat dobrou radu ale to neznamena ze to co se jim libi se bude libit me

- Bud'to ho uš dlouho používají a chtějí o něm informovat ostatní a nebo za něj mají dost peněz aby jim to bylo jedno

- Neznám prostě nějaké ,influencery absolutně nevím kdo to je. Ale $z$ úvodu jsou tam napsáno youtubeři. Youtubery sleduji, většinou tam spíš mají recenze na hry nebo stránky na to jak si danou hru koupit či najít. Někteří tam mají zase svi̊j merch. K otázce - kdybych dala proč 
prodávají svůj merch. Myslim, že je to proto, že si tak rozvíjí svojejméno trochu dál.

- Placená propagace, nebo prostě z přesvědčení, že věc opravdu funguje a je „dobrá“.

- Pro peníze, vice sledujících, aby byli zajímavější. Ale taky treba mohou s nimi mit dobre zkušenosti a chtějí je prostě jenom podpořit.

- Pokud jsou youtubeři nebo streameři, tak nemají na výběr, protože $z$ pouhé sledovanosti se nedá uživit, proto musí sáhnout po tzv. propagaci při které dostanou vysoké částky.

- Za vším jsou peníze. Jedna z největších motivací lidstva, což samozřejmě neznamená, že je to dobrá věc, ale at' už se to komukoliv líbí nebo ne, vždy to tak bylo a bude.

- někteří protože souhlasí s tím že je výrobek velmi dobrý (např. KOVY) a někteří pro penize

- Některým jde o peníze, někteří se prostě chtějí podělit o věc která jim vyhovuje. Každý člověk je jiný, ale já většinou stejně na ty předražený blbosti nemám peníze a když už je mám, tak si radši koupím něco co doopravdy potřebuji.

- nevadí mi to jen pokud propagaci označí a není to nějaká hovadina.

- Kvůli penězum nikdo by to neudělal zdarma

- Dle mého názoru se dělí na 2 skupiny. 1 skupina propaguje něco čemu opravdu věři . 2 skupina propaguje věci o, kterých není skutečně přesvědčena.(obou skupinám jde o peníze,jelikož také potřebují nějak vydělávat. Ale myslím si, že 1 skupině záleží na tom, aby jim lidé věřili a, aby svým jménem nepropagovali žádné nekvalitní věci.) Někdy však může být těžké tyto 2 skupiny odlišit.

\section{Napodobování životního stylu influencerů}

Influenceři mohou být vzory, které chtějí jejich sledující napodobovat. Někteří z influencerů sdílejí kvalitní a inspirativní obsah a mohou se podílet i na edukaci dětí, někteří naopak kvalitní obsah nevytvářejí a mohou své sledující negativně ovlivňovat. Proto je jedním z úkolů mediální výchovy vybavit žáky potřebnými znalostmi, aby byli schopní tyto dva druhy influencerů rozlišovat. V našem výzkumu jsme se zaměřili na to, zda žáci napodobují životní styl influencerů (z hlediska stravovacích návyků) a zda žáci drželi někdy dietu nebo dodržovali cvičební režim, aby se podobali svému oblíbenému influencerovi. Výsledky jsou ukázány v následujících grafech. 
Graf č. 8 Napodobování alternativního životního stylu (vegetariánství, veganství, raw strava apod.) influencerů

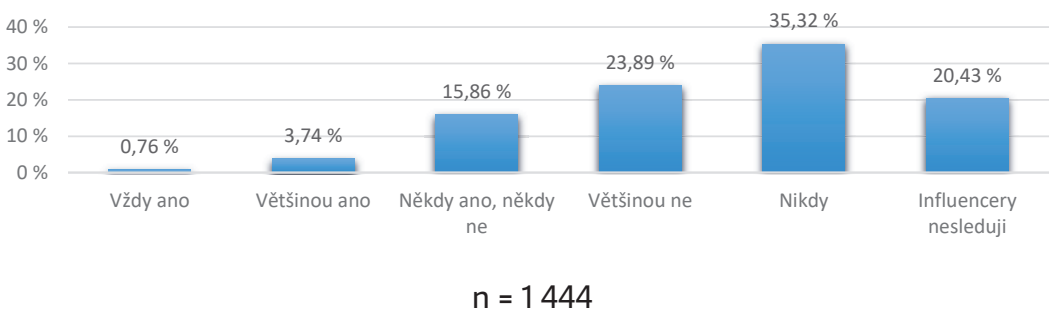

V současné době se na sociálních sítích setkáváme s tím, že influenceři doporučují svým sledujícím určitý alternativní životní styl, který sami vyznávají. Může se jednat o vegetariánství, veganství, raw stravu, low carb stravu, paleo dietu a mnoho dalších. Vše může být doplněno propagací výrobků, které s alternativním životním stylem souvisejí, a fotografiemi či videi, které daný životní styl představují jako ten jediný správný. Problém je, že velká část těchto influencerů nemá dostatečné vzdělání na to, aby mohla zvolený životní styl označovat za nejlepší možný. Co vyhovuje danému influencerovi, nemusí v žádném případě vyhovovat sledujícím uživatelům. V nejhorším případě může při napodobování určitého životního stylu docházet k zdravotním komplikacím nebo poruchám př́jmu potravy, obzvláště pokud k napodobování dochází v nízkém věku.

$Z$ dat plyne, že vždy napodobuje alternativní životní styl influencerů jen velmi nízké procento žáků (0,76 \%) a většinou 3,74 \% žáků. Odpověd' někdy ano, někdy ne uvádí 15,86 \% žáků. Skoro čtvrtina žáků (23,89 \%) životní styl influencerů většinou nenapodobuje a více než třetina (35,32 \%) žáků životní styl nenapodobuje nikdy. Influencery nesleduje 20,43 \% žáků. Z toho plyne, že žáci jsou alternativním životním stylem influencerů ovlivněni opravdu minimálně, ne-li vůbec. 
Graf č.9 Snaha podobat se oblíbenému influencerovi pomocí držení diet nebo dodržování cvičebního režimu

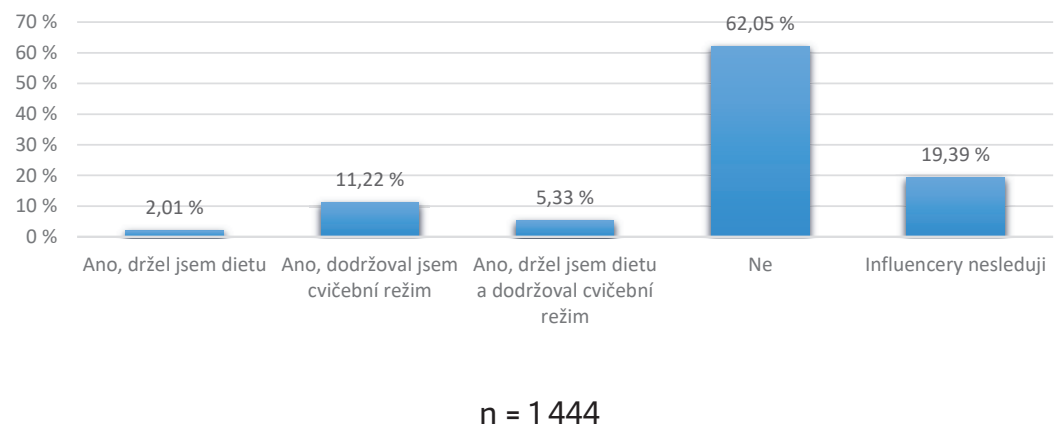

V této položce nás zajímalo především napodobování vizuální stránky oblíbených influencerů. Zajímalo nás, jestli žáci někdy drželi dietu nebo dodržovali cvičební režim, aby se podobali vzhledu svého oblíbeného influencera. Pouhých 2,01 \% žáků uvádí, že někdy drželi dietu, aby se podobali oblíbenému influencerovi. Toto nízké procento vnímáme velmi pozitivně, protože držet dietu bez lékařského dohledu ve věku, kdy dochází k vývinu organismu, může mít vážné zdravotní dopady. Cvičební režim dodržovalo 11,22 \% žáků a někdy drželo dietu a také dodržovalo cvičební režim 5,33 \% žáků. Více než polovina žáků ( $62,05 \%)$ nikdy nedržela dietu ani nedodržovala cvičební režim a 19,39 \% uvádí, že influencery nesleduje.

\subsubsection{Nenávistné příspěvky na sociálních sítích}

V závěrečných položkách této části dotazníku jsme se zabývali nenávistnými př́spěvky na sociálních sítích. Zajímalo nás, zda žáci někdy nějaký nenávistný příspěvek napsali a pokud ano, na koho tento příspěvek útočil. Dále jsme se zaměřili na to, jestli žáky četba nenávistných příspěvků negativně ovlivňuje a zda i oni sami byli někdy obětí nenávistných př́ispěvků a proč. Výsledky výzkumu jsou shrnuty v následujících grafech a tabulkách. 
Grafč.10 Napsali žáci někdy nenávistný příspěvek na sociální sítě?

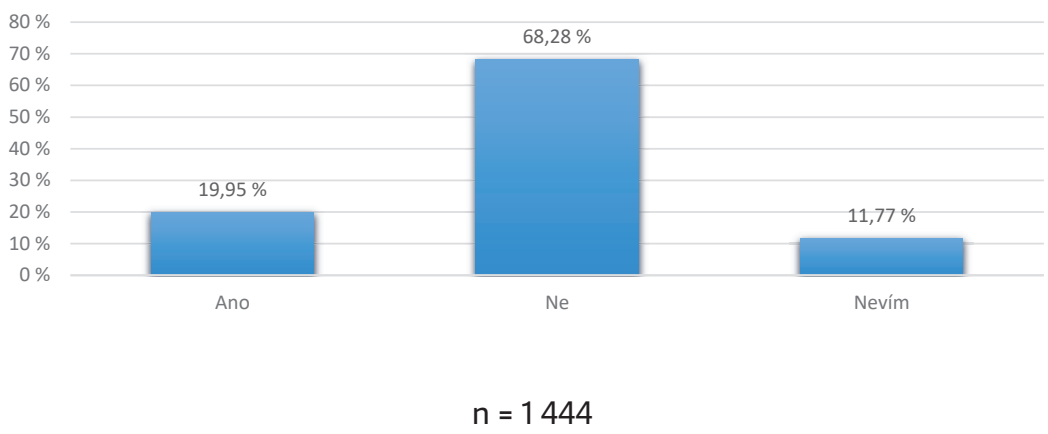

Více než polovina (68,28 \%) žáků nikdy nenapsala nenávistný příspěvek na sociální sítě. Žáků, kteří neví, zda nějaký nenávistný komentář napsali, je 11,77 \%. Téměř pětina $(19,95 \%)$ žáků někdy nějaký nenávistný příspěvek napsala. Tito žáci měli v následující položce zvolit, na koho nenávistný příspěvek útočil. Mohli vybrat libovolný počet odpovědí z nabízených možností nebo mohli napsat vlastní odpověd' (pomocí možnosti „jiné“). V následující tabulce vidíme jejich odpovědi, přičemž 62,74 \% žáků se k položce nevyjádřilo a odpovědi, které s otázkou nesouvisely, jsme do tabulky nezaznačili.

Tab. č.5 Na koho útočily nenávistné přispěvky na sociálních sítích

\begin{tabular}{|l|c|c|}
\hline & $\begin{array}{c}\text { Absolutní } \\
\text { četnost }\end{array}$ & $\begin{array}{c}\text { Relativní } \\
\text { četnost }\end{array}$ \\
\hline $\begin{array}{l}\text { na veřejně známé osobnosti (např. zpěváci, herci, } \\
\text { youtubeři, influenceři, politici...) }\end{array}$ & 138 & $9,56 \%$ \\
\hline $\begin{array}{l}\text { na fyzický vzhled oběti (např. nadváha, podváha, } \\
\text { oblečení, tetování...) }\end{array}$ & 45 & $3,12 \%$ \\
\hline $\begin{array}{l}\text { na př́slušníky etnických skupin (např. Romové, } \\
\text { Arabové, Vietnamci, černoši...) }\end{array}$ & 35 & $2,42 \%$ \\
\hline $\begin{array}{l}\text { na příslušníky náboženských skupin (např. } \\
\text { muslimové, Židé, křesțani...) }\end{array}$ & 28 & $1,94 \%$ \\
\hline $\begin{array}{l}\text { na příslušníky homosexuální orientace } \\
\text { jiné }\end{array}$ & 28 & $1,94 \%$ \\
\hline n = 1444 & 105 & $7,27 \%$ \\
\hline
\end{tabular}


Pokud někteří z žáků napsali nenávistný příspěvek na sociální sítě, tak se nejčastěji týkal veřejně známé osobnosti, at' už o zpěváka, herce, youtubera, influencera apod. Tuto možnost zvolilo 9,56 \% žáků. Dále se nenávistné příspěvky týkaly fyzického vzhledu oběti (3,12 \%) a její příslušnosti k určité etnické skupině (2,42 \%). Stejnou měrou (1,94 \%) byly zastoupeny nenávistné příspěvky útočící na příslušníky náboženských skupin a homosexuální orientace. Často se také objevovala odpověd' „jiná“ (7,27 \%), kde žáci mohli napsat svoji zkušenost s nenávistnými příspěvky bez ohledu na nabízené odpovědi. Opakovaly se podobné typy odpovědí - žáci se chtěli pomstít někomu, kdo si to zasloužil („Když už jsem nějaký 'hate' komentář napsala, tak proto, že ten daný člověk zase dával 'hate' na někohojiného, třeba koho mám ráda“; Na pubertáka, který urážel, ponižoval a povyšoval se nad mladší osobou. Bližší mého věku. “), poukázat na nemorální chování („Na influencera, který propagoval stránku s hazardem mezi své publikum, které je tvořeno dětmi od 10 do 15 let"; "Na falešný profil s falešnými soutěžemi“), vyjádřit se k týrání zvířat („týrání zvířat“; "Na týrání psů (zvírat) v jiných zemích") a dělat si srandu z kamarádů („Napsal jsem to kamarádovi a oba dva jsme věděli, že je to ze srandy.“).

Mimo jiné nás v rámci výzkumu zajímalo také to, zda jsou žáci četbou nenávistných příspěvků negativně ovlivněni. Jejich odpovědi jsou zaznačeny v následujícím grafu.

Graf č.11 Jsou žáci negativně ovlivněni četbou nenávistných př́spěvků?

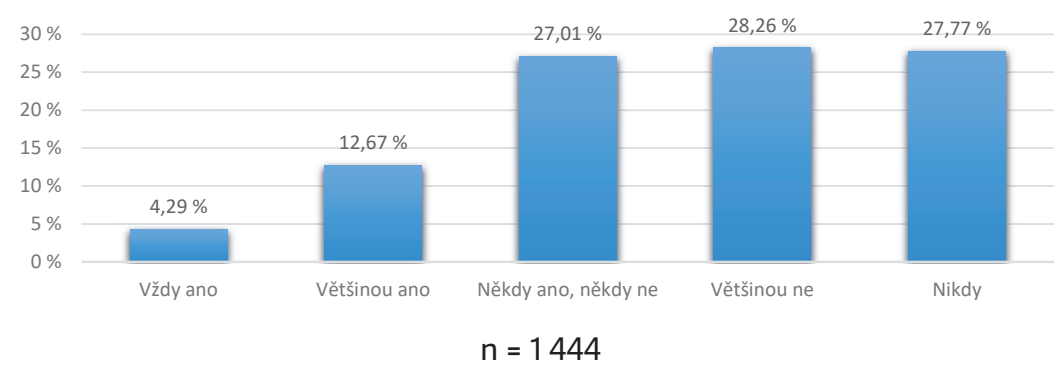

Četbou nenávistných příspěvků většinou není negativně ovlivněno 28,26 \% žáků a tyto příspěvky vůbec negativně neovlivňují 27,77 \% žáků. Podobné procento $(27,01 \%)$ žáků je těmito příspěvky někdy negativně ovlivněno a někdy ne. Četba nenávistných příspěvků většinou ovlivňuje 12,67 \% žáků a malé procento žáků $(4,29 \%)$ je negativně ovlivněno vždy. Můžeme tedy tvrdit, že pokud žáci čtou nenávistné příspěvky na sociálních sítích, tak jimi většinou nejsou negativně ovlivněni, což může poukazovat na to, že si žáci dokážou stanovit hranice $\mathrm{v}$ tom, do jaké míry na sebe nenávistný a nega- 
tivní obsah na sociálních sítích nechávají působit. Budování těchto hranic by měla rozvíjet právě mediální výchova, která učí žáky rozeznávat, co je nesouhlasný či kritický postoj k určité problematice, a co už je nenávistný příspěvek, který má za cíl vyvolat odpor či strach.

Na závěr této části dotazníku jsme žákům položili otázku, jestli oni sami byli někdy obětí nenávistných příspěvků. Pokud ano, měli možnost své zkušenosti popsat v otevřené položce. Jednotlivé odpovědi si opět ukážeme v následujícím grafu a tabulce.

Graf č.12 Byli žáci někdy obětí nenávistných příspěvků na sociálních sítích?

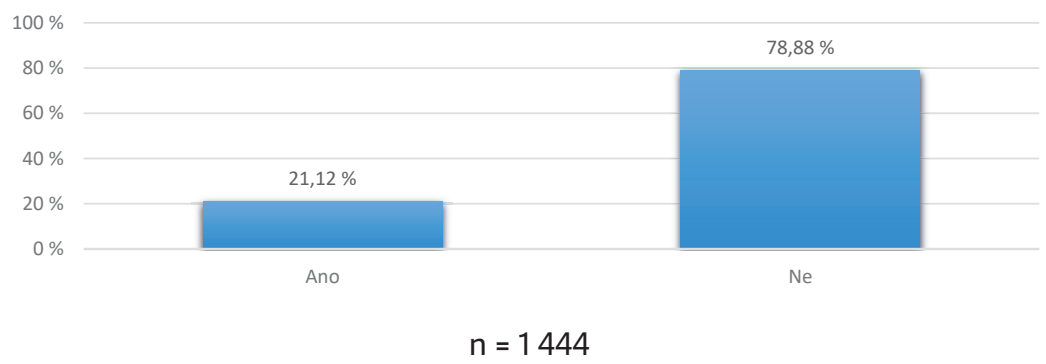

Obětí nenávistných příspěvků na sociálních sítích nikdy nebylo 78,88 \% žáků. Více než pětina (21,12 \%) žáků byla někdy obětí těchto příspěvků. Čeho se příspěvky týkaly, si uvedeme v tabulce, přičemž 72,99 \% žáků se k položce nevyjádřilo a odpovědi, které byly nesouvisející či se objevovaly minimálně, jsme do tabulky nezaznačili.

Tab. č. 6 Čeho se týkaly nenávistné příspěvky na sociálních sítích

\begin{tabular}{|l|c|c|}
\hline Vzhled & $\begin{array}{c}\text { Absolutní } \\
\text { četnost }\end{array}$ & $\begin{array}{c}\text { Relativní } \\
\text { četnost }\end{array}$ \\
\hline Osobnost (vlastnosti a názory) & 112 & $7,76 \%$ \\
\hline Něco jsem neuměl/a, udělal/a jsem chybu & 65 & $4,50 \%$ \\
\hline Sexuální orientace & 15 & $1,04 \%$ \\
\hline
\end{tabular}

$$
n=1444
$$


Nejčastěji se nenávistné příspěvky týkaly vzhledu žáků (7,76 \%), přičemž velmi často byla zmiňována nadváha. Dále příspěvky útočily na osobnost žáků (4,50 \%), a to především na jejich názory, vlastnost a životní styl. Objevovaly se také útoky na to, když žák dělal něco špatně nebo mu něco nešlo (1,04 \%) a když byl žák odlišné sexuální orientace (0,76 \%). Níže uvádíme některé z ukázek odpovědí žáků (záznamy žáků neprošly jazykovou úpravou):

- Kvůli toho ze jsem třeba delala něco blbě atd

- Podle tohojak vypadám.

- Asi něco v tom smyslu, že jsem blbá vegetarianka atd..

- O tom že jsem tlustý

- Mého vzhledu nebo minulosti

- Nadváhy

- Chování, rozdílnosti, slabosti...

- pomluv o mém přátelství s daným člověkem

- Vzhledu, vystupování.. Lidi, ale převážně děti si vždy něco najdou, proč se někomu smát. Jde o to si s tím nelámat hlavu a nevšímat si toho.

- Že jsem hnusná, měla bych zhubnout

- Toho že moje usuzování, a přemýšlení je špatné. Že sem hloupej. Že patřím k skupinám, ke kterým nemám nic společného.

- týkali se hlavně mé postavy a mé orientace......vím že jsem malinko odlišná ale i tak jsem stále člověk který má právo žit hezký život.....podle mě člověk s nadváhou, s jinou barvou pleti nebo s odlišným vkusem je pořád ČLOVĚK tak nevidím důvod proč by někdo měl těmto lidem nadávat..... já to beru tak že člověk co mi nadává mi závidí (sice nevím co ale prostě kdyby nezáviděl tak ani nenapíše) jsem ráda za to jaká jsem.... jsem hrdá na to že jsem zvládla o sobě říct jaká je má orientace.... ale i tak mám hodně špatnou náladu z toho když vidím že mi někdo napíše že jsem odporná...že se na mě nedá dívat nebo že bisexualita je nemoc.... taky nechápu proč existují homofóbní lidé...

- Vzhledu postavy

- Můj vzhled... Od té doby nepostuji své fotky

- Třeba kvůli tomu, že perfektně neumím co na videu ukazuji, nebo prostě jen sprostánadávka bez vysvětlení.. Od té doby mám soukromé účty a vypnuté komentáře

- Že jsem „negramot". Jsem ale dislektik, disgrafik a disortografik. Nic si $z$ komentářủ nedělám.

- Vzdy vzhledu.

- tloušt'ka 
- Překlikla jsem se a napsala špatnou číslici ve váze svého psa. Nějaký člověk (nejspíš odborník na psy Xd) mi začal nadávat, že můj pes má ošklivou nadváhu a že jsem ... když se o něj tak špatně starám.

- Toho jak moc hubená jsem prritom vážím přiměřeně ke svému věku a výšce a kvůli tomu že se lidé nedokázali smířit s pravdou nebo s tím jakjsem říkala upřímné názory na ně, nesnáším lež proto mluvím pravdivě a upř́mně.

- mé tlouštky, na instagramu jsem dala fotku z narozenin a seděla jsem na zemi a mé břicho byly vidět jelikož jsem měla croptop.....většinaspolužáků i lidi co znám size mě utahovala, fotku jsem do dvou dnů smazala

- většinou mi pod př́spěvky psali, at’ se jdu zabít, at' chcípnu, že jsem divná atd.

- nakažení korovirem

- váhy.žejsem napsala špatně slovo anglicky tím pádem jsem byla hloupá

- Body shaming, svoje sexuální orientace

- Že to co dělám nemá cenu, nebo se na mě nedokáží dívat

- Nadváhy, tichost kvůli které si myslí, že nejsem dostatečně chytrá, kvůli jiným zájmům.

- Lidé se mi smáli, že jsem na holky. Dělali homofobické nadávky a vysmívali se, že nepouživám ani jedno pohlaví na určení mé identity.

- Člověk co ten komentár psal jsi myslel že jsem Arabka, tak psal At' vypadnu zpátky do své země apod.

- Neznalosti v oboru a mého špatného osobního názoru.

- toho jak vypadám, že jsem tlustá, že ničeho nikdy nedokážu, že jsem kráva, že neumím zpívat, že moje rodiče jsou strašně špatní, „, nechtěl bych mít tvoje rodiče za svoje rodiče. " „máš to tam jak v děcáku ", , si děvka“", „si zlaokopka ", „s tím klukem si jen kvůli jeho penězům a ne kvůli lásce“" „lesbo“ (jsem totiž bisexuálka) celkově mi takhle nadávali. pak mi taky nadávali že jsem na starší..

- barva pleti

- mého vzhledu a partnerů

- jednou jsem dala fotku mého oka na instagram tu fotku mám sice smazanou ,ale jeden kluk mi psál že jsem monstrum naštěstí mě to ovlivnilo ps: tu fotku jsem si smazala , protože mně ta fotka přišla trapná

- Lidem se nelíbilo že si užívám život a mám své koníčky

- Často mi lidi na Tellonym (anonymní aplikace) psaly že jsem: kráva, děvka, jestli mně baví všude vystrkovat prdel, že se hnusně oblékám, že jsem kurva, kráva, píča....atd bylo toho dost ale já si z toho nic nedělám, je to pouze jejich názor ale nechápu jak můžou napsat 12 letý holce že je kurva! Kdyžjsem z toho byla smutná tak jsem šla za kámošema, nechtěla 
jsem do toho tahat rodinu, nechci dělat problémy! Ale určitě bych to nenazvala šikana to ne! Když si stahujete tuhle aplikaci takje jasný, že vám to tam budou psát, protože jsou zbabělí a do očí vám to neřeknou. Ale upř́mně mněje jedno že mi to tam psali,je to jen jejich názor! Okolo sebe mám tolik skvělých kamarádů a kamarádek, který kdyby se dozvěděli kdo to tam psal tak by ten člověk měl problém, nebo by mu dali přes "hubu".

- Ǩ́ḱkali že mám tlusté ruce

- že mám nadváhu, a že bych neměla tohle nosit že v tom vypadám jak buřt nebo tak něco, že jsem divná když poslouchám jinou hudbu než většina lidí mého věku

\subsection{Dotazník - 2. část}

V této části dotazníku jsme se zaměřili na to, do jaké míry se žáci 2. stupně ZŠ orientují ve vybraných aktuálních problémech mediální výchovy. Použili jsme reálné příklady dezinformace, hoaxu, falešných internetových profilů a fotografií, product placementu, sexismu v reklamách, klamavé reklamy, mediálních stereotypů, hatingu a veřejnoprávních médií.

Výzkumné otázky, na které pomocí této části dotazníku hledáme odpověd', jsou:

- Do jaké míry se žáci 2. stupně ZŠ orientují ve vybraných aktuálních problémech mediální výchovy?

- Jsou žáci 2. stupně ZŠ schopni na základě názorných př́ikladů rozeznat dezinformace, hoaxy, falešné internetové profily a fotografie, product placement, sexismus v reklamách, klamavou reklamu, mediální stereotypy, hating a veřejnoprávní média?

Jednotlivé položky si na následujících stranách podrobně rozebereme, přičemž každá z položek bude představena tak, jak byla prezentována v dotazníku, následně bude doplněna o výzkumnou podotázku (znázorněna tučnou kurzívou), na kterou hledá odpověd', a zároveň bude obsahovat graf jednotlivých odpovědí a dále graf správných a chybných odpovědí žáků 2. stupně ZŠ vytvořený na základě výše zmíněného způsobu hodnocení. Některé z položek budou doplněny komentářem vysvětlujícím, proč jsme danou položku zvolili jako modelový př́klad. V závěru této podkapitoly provedeme komparaci průměrného počtu bodů z obou variant dotazníku a pomocí krabicových grafů si znázorníme rozdíly v počtu bodů mezi dívkami a chlapci a mezi jednotlivými třídami. 
Tento př́spěvek se objevil na Facebooku. Jedná se o:

\section{Marek}

\section{Šok $\vee$ koloniálu, INFORMUJ VŠECHNY!!!!!!}

Do minulého týdne jsem to netušil, ale romové nemusí platit za máslo. Byl jsem $v$ obchodě koupit dětem gothaj a tavený sýr atd. Přede mnou byla menšina, wbrali si máslo a pak wytáhli papír ze sociálky ... prodavačka ho potvrdila a odešli. Ptal jsem se, co to bylo a ona mi sdělila, že jsou sociálně slabí, tak jim stát platí másı.

Málem to se mnou seklo, zaplatil jsem $80,-K c ̌$ a naštvaně šel domủ.

Pracuji, platím SP, ZP, daně - a to všechno na ně a jim podobným.

PROSÍM,SDÍLEJTE TO DÁL,S TÍM UŽ SE MUSÍ NĚCO UDĚLAT!!!!!!!!!!!!!!
(1) To se mi líbi
Komentáŕ
Sdilet
○-
(1) $\div 8$

A. zkušenost autora zakládající se na skutečných událostech

B. hoax (falešná poplašná zpráva) ${ }^{13}$

C. skrytou reklamu na zlevněné máslo

Komentář: U této položky považujeme za zásadní uvést důvody, proč se jedná o modelový příklad hoaxu. Hoaxy často obsahují apel na sdílení a okamžitou aktivitu (,....informuj všechny“, ,....sdílej to dál“ ${ }_{,}, \ldots .$. s tím už se musí něco udělat"), přičemž důležitost sdělení je podpořena velkými písmeny a množstvím vykřičníků. Hoaxy mají za cíl vzbuzovat emoce („šok“) a zpravidla se týkají určité menšiny (v tomto případě Romů), která nemá ve společnosti př́liš dobrou pověst a pojí se s ní řada stereotypů. Také často odkazují na kulturní kontext a na problémy, které ve společnosti rezonují

13 Správné odpovědi budou zvýrazněny. 
v určitém časovém úseku (v době, kdy se šśřil tento hoax, bylo velmi drahé máslo). Pokud bychom se podívali na ostatní hoaxy, které se šírily společností, našli bychom v nich s velkou pravděpodobností podobné znaky, jako má výše zmíněný hoax.

Graf č.13 Schopnost rozeznat hoax - jednotlivé odpovědi

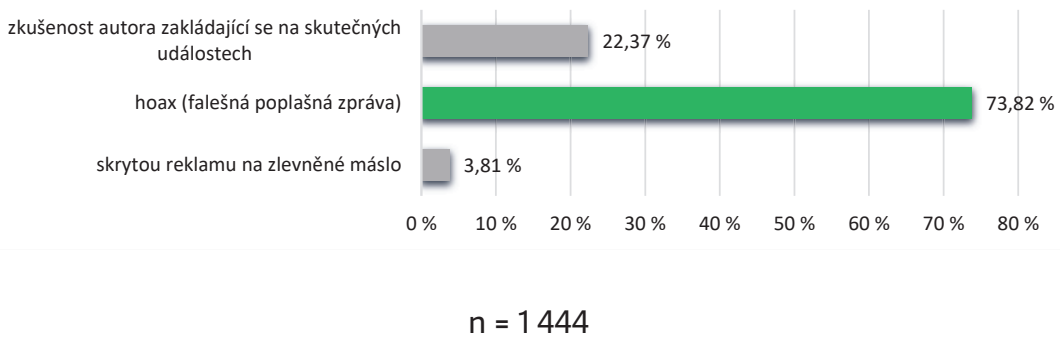

Graf č. 14 Schopnost rozeznat hoax - správné a chybné odpovědi

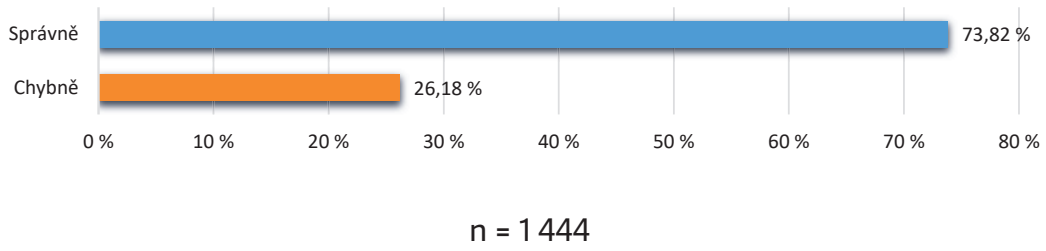

Správně odpovědělo 73,82 \% respondentů, chybně 26,18 \% respondentů, přičemž 22,37 \% si myslí, že se jednalo o zkušenost autora zakládající se na reálných událostech. To, že se jedná o hoax, správně určilo 73,82 \% respondentů. Nízké procento žáků $(3,81 \%)$ se domnívá, že jde v tomto př́padě o skrytou reklamu na zlevněné máslo. 
POLOŽKA 2: Znají žáci význam zkratky PP, která se může objevovat $v$ médiích?

Na obrázku vidíte screenshot z vysílání televizního pořadu Toulavá kamera. Co znamená značka PP vpravo dole?

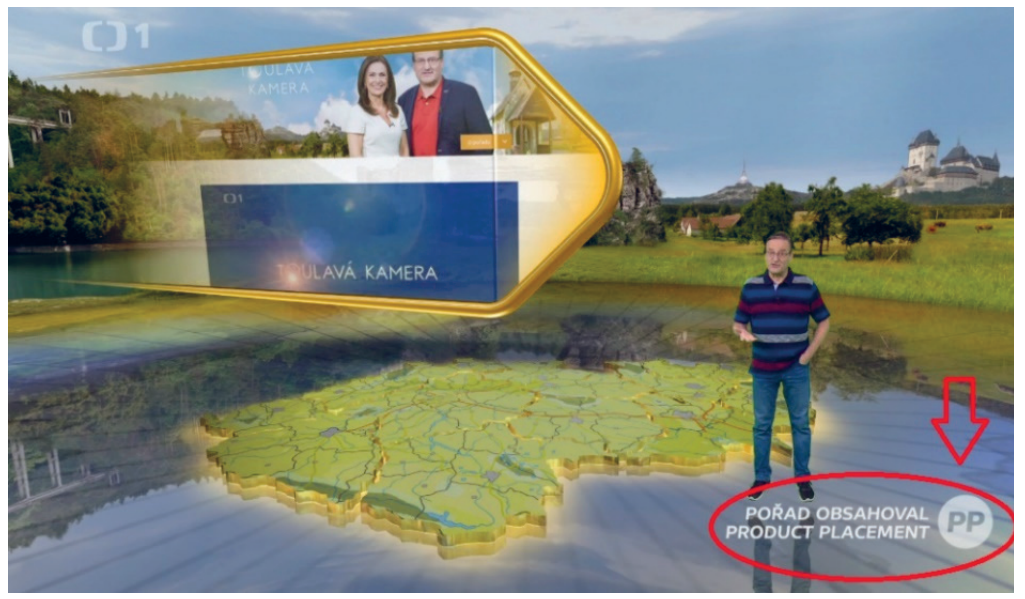

Obrázek 2 Product placement

A. jedná se o zkratku organizace, která pořad produkuje

B. jedná se o skrytou reklamu, která je součástí pořadu

C. jedná se o odkaz na e-shop pořadu

Graf č. 15 Význam zkratky PP - jednotlivé odpovědi

jedná se o zkratku organizace, která pořad produkuje

jedná se o skrytou reklamu, která je součástí pořadu

jedná se o odkaz na e-shop pořadu

$0 \%$

$\mathrm{n}=1444$
$27,63 \%$

$4,16 \%$

$20 \%$

$30 \%$

$40 \%$

$50 \% \quad 60 \%$

$70 \% \quad 80 \%$ 
Graf č. 16 Význam zkratky PP - správné a chybné odpovědi

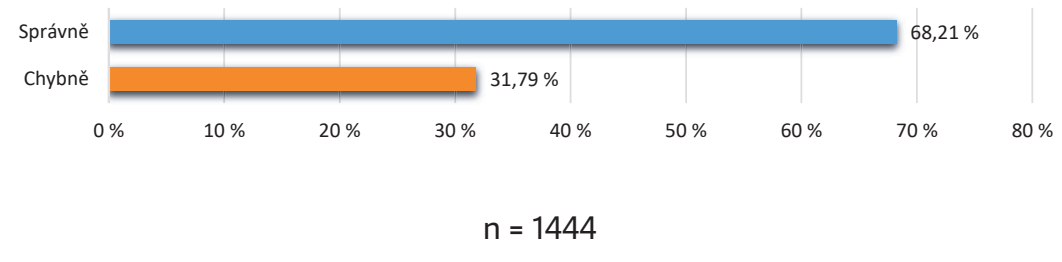

Správně na otázku odpovědělo 68,21 \% žáků, chybně 31,79 \%. Více než čtvrtina žáků (27,63 \%) si myslí, že zkratka PP odkazuje na organizaci, která pořad produkuje, a 4,16 \% žáků si myslí, že jde o odkaz na e-shop pořadu. Více než 2/3 žáků $(68,21 \%)$ zná správný význam zkratky PP, která odkazuje na to, že pořad obsahuje reklamu, která nemusí být na první pohled patrná. 
Co znamená „fake news"?

A. obecné označení pro autory zpráv, kteří se snaží zůstat v anonymitě

B. Iživé a nepravdivé zprávy

C. označení pro soukromá média

Graf č. 17 Význam pojmu "fake news" - jednotlivé odpovědi

obecné označení pro autory zpráv, kteří se snaží zůstat v anonymitě

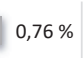

lživé a nepravdivé zprávy

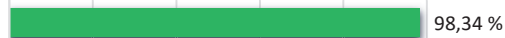

označení pro soukromá média

$0,90 \%$

$0 \%$

$20 \%$

$60 \%$

$80 \% \quad 100 \%$

$$
n=1444
$$

Graf č. 18 Význam pojmu „fake news" - správné a chybné odpovědi

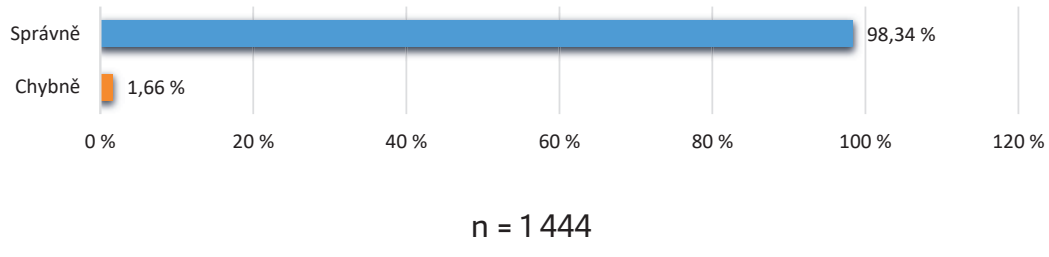

Jedná se o položku s nejvyšším procentem správných odpovědí (98,34 \%), tudíž téměř všichni žáci znají význam pojmu „fake news“ jako lživé či nepravdivé zprávy. Pouhých 0,76 \% žáků se domnívá, že pojem označuje autory zpráv, kteří chtějí zůstat v anonymitě, a pro 0,9 \% žáků pojem označuje soukromá média. Chybně tedy odpovědělo jen 1,66 \% žáků. 
Na obrázku vidíte facebookový profil prezidenta ČR Miloše Zemana. Jedná se o jeho skutečný oficiální facebookový profil?

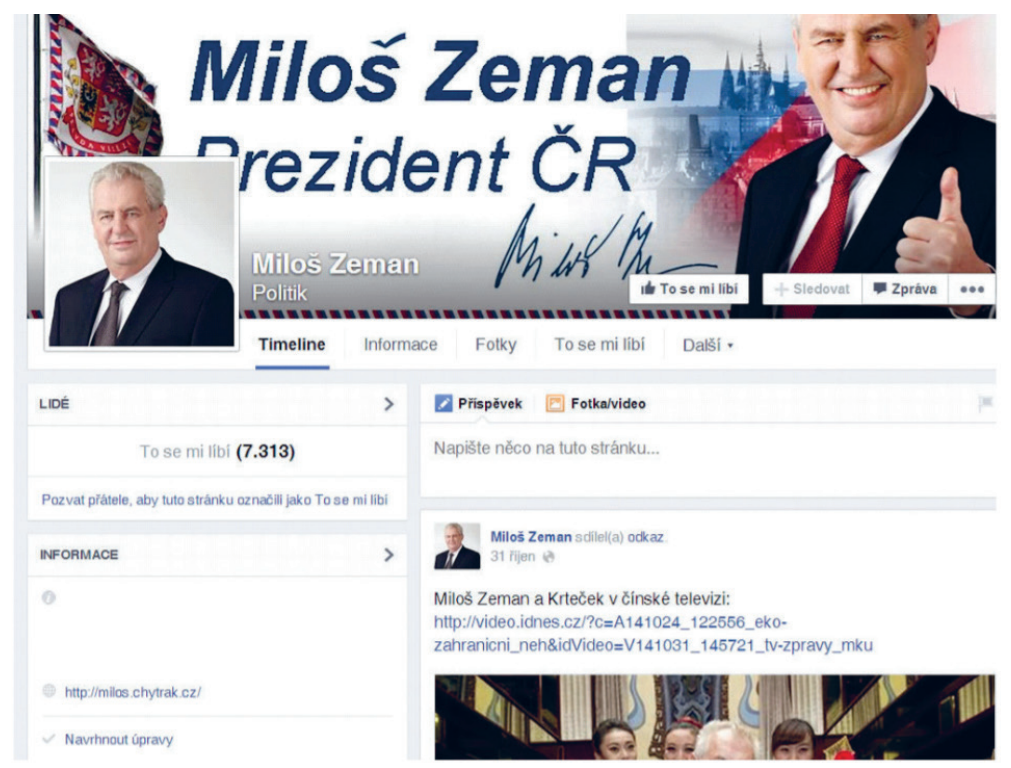

Obrázek 3 Miloš Zeman (Facebook)
A. ANO
B. NE

Komentář: U této položky uvádíme, proč se jedná o modelový příklad falešného facebookového účtu (profilu). Základním znakem je, že tento profil neobsahuje ověřující symbol (tzv. verified button) - malý modrý puntík s bílou fajfkou uprostřed nacházející se hned vedle jména dané osoby. Dalším znakem, který je často spojován s falešnými profily, je počet sledujících uživatelů. Profily veřejně známých osobností, které obsahují velmi nízké číslo sledujících, jsou s velkou pravděpodobností falešné. Není tomu jinak ani v tomto případě, kdy je velmi nepravděpodobné, že by prezidenta ČR Miloše Zemana sledovalo tak nízké číslo uživatelů. Dalším znakem, který se 
může pojit s falešnými účty, je odkaz na zavádějící webové stránky nacházející se v části „informace“ nebo v jiných částech profilu. $V$ tomto případě zde můžeme vidět odkaz na webovou stránku http://milos.chytrak.cz, kterou by na svém oficiálním profilu hlava státu zajisté neměla. Vše tedy napovídá tomu, že profil je falešný.

Graf č. 19 Falešný profil na Facebooku -jednotlivé odpovědi

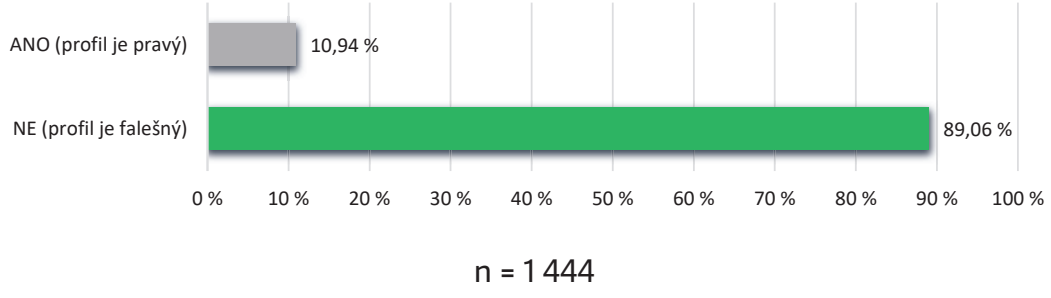

Graf č. 20 Falešný profil na Facebooku - správné a chybné odpovědi

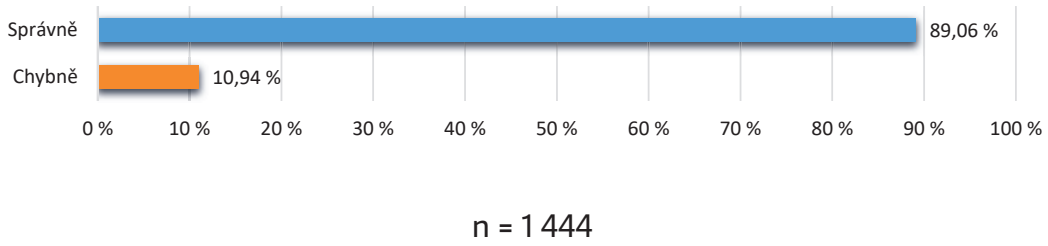

Falešný profil na Facebooku správně poznalo 89,06 \% respondentů a 10,94 \% respondentů si myslelo, že je profil pravý. 
Mezi veřejnoprávní média NEPATří (pozn. více správných odpovědí):
A. Televize Nova
B. Česká televize
C. Česká tisková kancelář
D. Televize Barrandov
E. Český rozhlas

Graf č. 21 Veřejnoprávní média-jednotlivé odpovědi

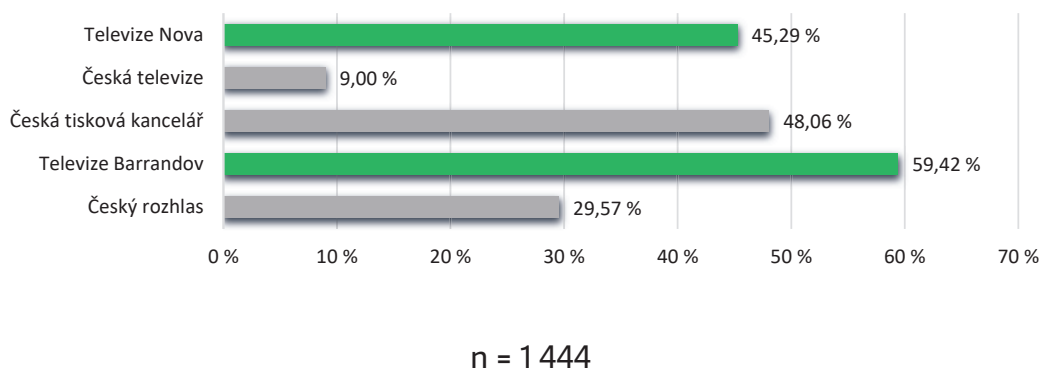

Graf č.22 Veřejnoprávní média - správné a chybné odpovědi

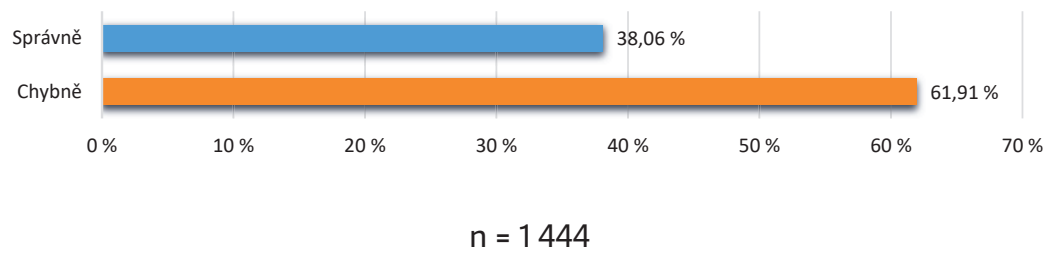

V této položce měli žáci na výběr z více správných odpovědí. Nejvíce žáků (59,42 \%) zvolilo odpověd' Televize Barrandov, následuje 48,06 \% žáků, kteří zvolili odpověd' Česká tisková kancelář, a 45,29 \% žáků, kteří zvolili odpověd' Televize Nova. Odpověd' Český rozhlas vybralo 29,57 \% žáků a nejméně z nich ( $9 \%$ ) zvolilo odpověd' Česká televize. V dotazníkové variantě A by správně odpovědělo pouze 38,09 \% žáků, zbytek žáků (61,91 \%) by odpově- 
děl chybně. Na následujícím grafu můžeme vidět srovnání žáků, kteří byli hodnoceni podle dotazníkové varianty $A$ a podle dotazníkové varianty $B$ (detailní popis viz kapitola 2.5.1). V dotazníkové variantě $B$, která je hodnocena mírněji, by žáci obdrželi 918,6 bodu. $V$ prísněji hodnocené variantě $A$ by žáci obdrželi 550 bodů.

Grafč. 23 Srovnání variant hodnocení u položky č. 5

$$
n=1444
$$


Na obrázku vidíte webovou stránku, která poskytuje informace o hubnutí. Věř́te, nebo nevěříte informacím uvedeným na této stránce?

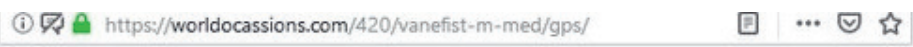

๑) CENTRAL SLIMMING INSTITUTE

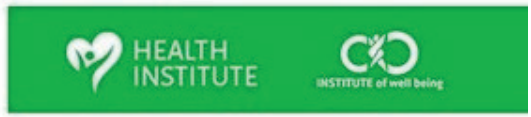

\section{Za 28 dní zhubnete 14 kg - efekt potvrzený nezávislými lékařskými testy}

Dobrý den,

Jmenuji se prof. Stefan Kubíček a jsem vědec, odbornik na molekulární biologii. Na této stránce bych vám rád představil svůj životní úspěch, za který jsem již obdržel přes deset prestižních oceněni. Vyvinul jsem prírodní kúru, díky níž každý může zhubnout až $14 \mathrm{~kg}$ za 28 dní - automaticky, bez diety a bez námahy.

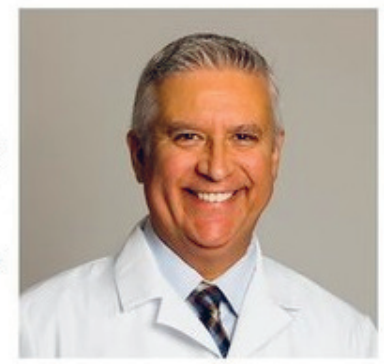

Obrázek 4 Klamavá reklama
A. Věrím
B. Nevěřím

Komentár̆: Tento druh klamavé reklamy se týká účinku výrobku, který slibuje nereálně rychlé zhubnutí, kterého je možno dosáhnout bez diety a bez námahy. To samo o sobě je velmi zavádějící. Reklama se dále opírá o doporučení odborníka (autority) prof. Stefana Kubička. Kdyby žáci měli možnost si jeho fotografii vyhledat, zjistili by, že stejný odborník vystupuje ve stejné 
klamavé reklamě v cizojazyčných zemích pod různými jmény (např. prof. Stefen Meier nebo Javier Gutiérrez).

Graf č. 24 Klamavá reklama -jednotlivé odpovědi

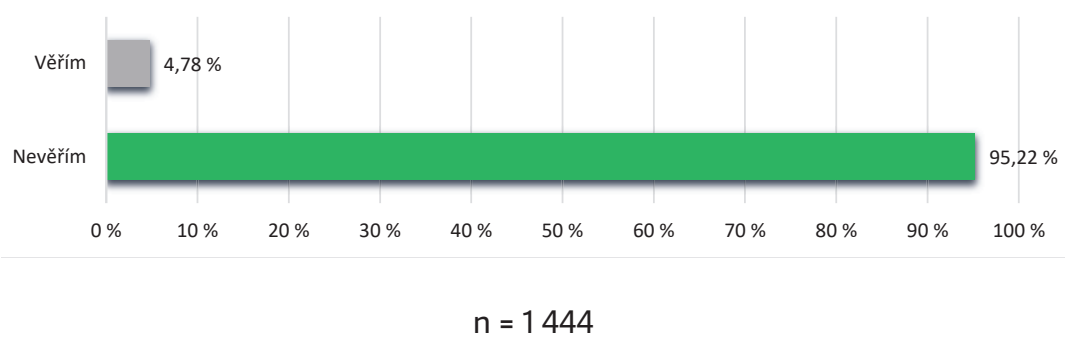

Graf č. 25 Klamavá reklama - správné a chybné odpovědi

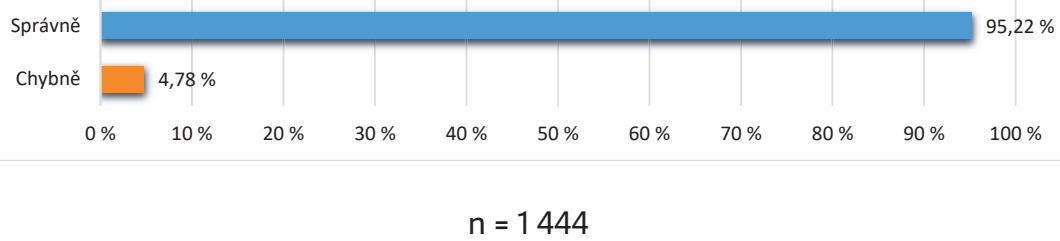

Na tuto otázku odpovědělo velké procento žáků (95,22 \%) správně - reklamě nevěří, chybnou odpověd' zvolilo 4,78 \% žáků - reklamě věří. 
Na Facebooku se objevila společná fotografie žáků 1. tř́idy ZŠ v Teplicích. Třída byla složena převážně z romských dětí a dětí arabského původu. Pod fotkou se objevila řada komentářů. Můžete $k$ dané fotografii na Facebook napsat takové komentáře (viz níže)?

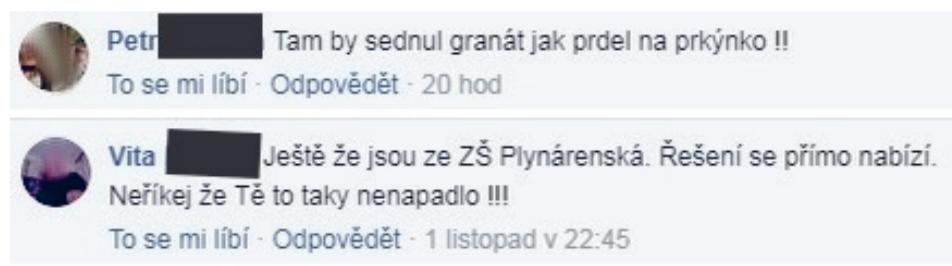

Obrázek 5 ZŠ Teplice-nenávistné př́spěvky
A. ANO, žijeme v demokratické společnosti a na internetu máme bez- meznou svobodu projevu
B. ANO, ale můžeme být obviněni z trestného činu „podněcování k nenávisti"
C. ANO, ale správci Facebooku takové komentáře inned smažou

Komentár̆: V tomto případě se jedná o typický příklad hatingu. Autoři příspěvků volají po násilných až drastických opatřeních vůči dětem na fotografii. Například autorovi spodního komentáře vyměřil soud podmíněný trest 16 měsíců s odkladem na 3 roky. Komentár̆ byl vyhodnocen jako projev nenávisti a její podněcování. V souvislosti s touto kauzou byli z podněcování k nenávisti obviněni i další autoři nenávistných příspěvků. 
Graf č. 26 Hating na sociálních sítích - jednotlivé odpovědi

ANO, žijeme v demokratické společnosti a na internetu máme bezmeznou svobodu projevu

ANO, ale můžeme být obviněni z trestného činu „podněcování k nenávisti“

ANO, ale správci Facebooku takové komentáře inned smažou

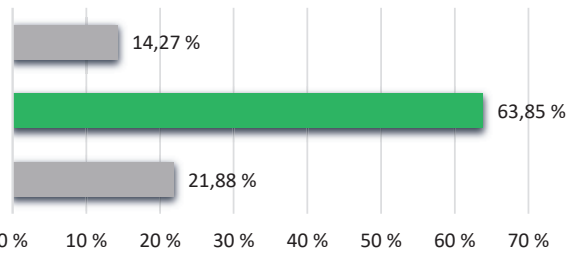

$n=1444$

Graf č. 27 Hating na sociálních sítích - správné a chybné odpovědi

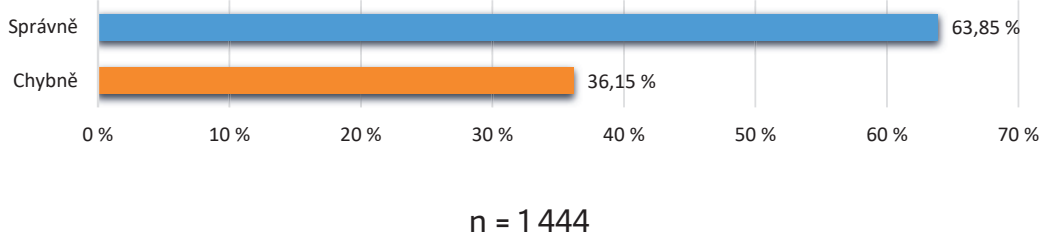

Správně na tuto otázku odpovědělo 63,85 \% žáků, kteří se domnívají, že za podobné nenávistné příspěvky mohou být obviněni z podněcování k nenávisti. Chybně odpovědělo 36,15 \% žáků, z nichž si 21,88 \% myslí, že Facebook podobné příspěvky smaže, a 14,27 \% se domnívá, že nenávistné příspěvky psát můžeme, protože na internetu máme neomezenou svobodu projevu. 
POLOŽKA 8: Poznají žáci xenofobní či dezinformační stránku na sociální síti Facebook?

Na obrázku vidíte facebookovou stránku We Are Here At Home .com. Tato stránka (pozn. více správných odpovědí):

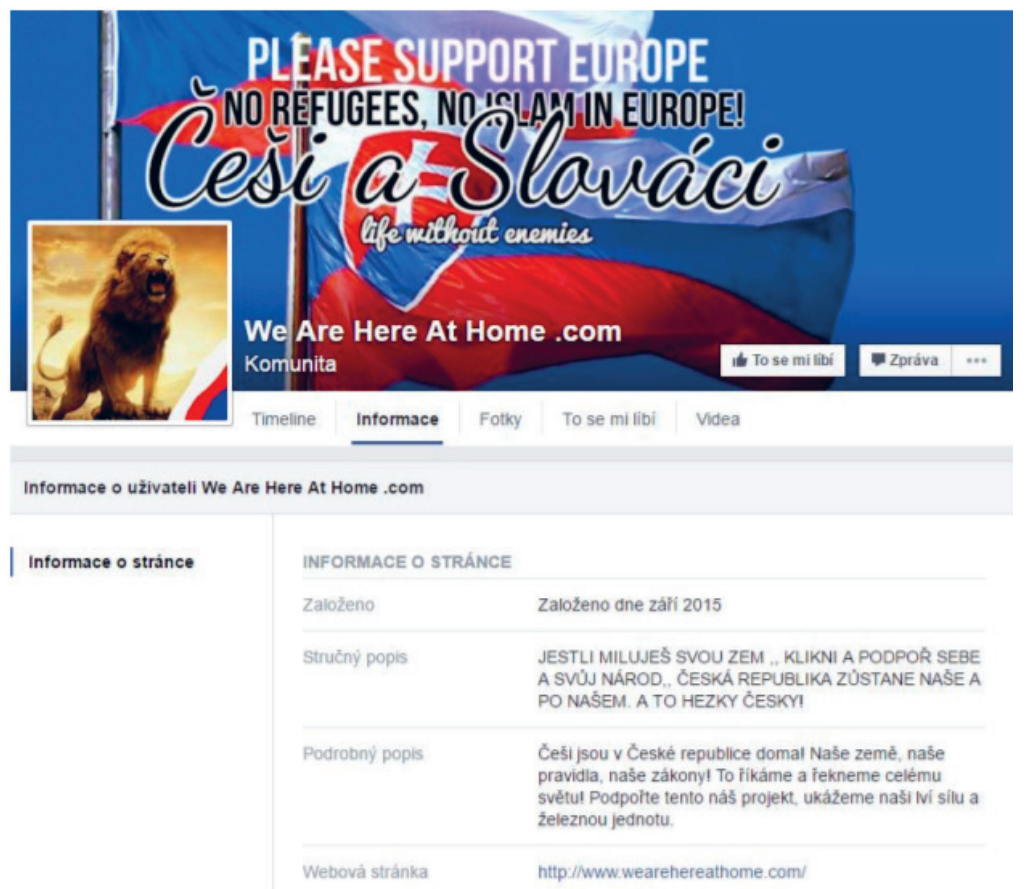

Obrázek 6 Dezinformační stránka na Facebooku
A. poskytuje tipy na cestování po ČR a Slovensku
B. je zaměřena proti migraci a islámu
C. podporuje migraci a islám
D. je silně nacionalisticky orientovaná 
Komentár̆: Stránka obsahuje několik znaků, které nám napoví, že může být problematická z hlediska nabízeného obsahu. Často se varovné signály objevuji již na úvodní fotografii, kde můžeme v tomto případě vidět hesla jako „no refugees“ (v překladu „žádní uprchlíci“), „,no islam in Europe“ (v překladu „žádný islám v Evropě) a „life without enemies“ (v překladu „život bez nepřátel"). Již z těchto znaků můžeme vytušit, že se bude ostře vymezovat vůči určité skupině osob, většinou vůči menšinám. Obdobná hesla bychom nalezli i na dalších stránkách s podobnou tematikou. Problematicky působí také popis stránky v dolní části, který je velmi vlastenecky pojatý. Sám o sobě by možná tak zavádějící nebyl, ale v kombinaci s výše zmíněným stránka tíhne ke xenofobii a k podpoře nacionalistických tendencí ve společnosti. Podobné stránky jsou problematické i z toho důvodu, že obsahují odkazy na další takové stránky, sdílejí dezinformace a podněcují ostatní uživatele k nenávisti. Zmíněnou stránku We Are Here At Home .com dnes na Facebooku už nenajdeme, protože byla smazána.

Graf č. 28 Dezinformační stránka na Facebooku - jednotlivé odpovědi

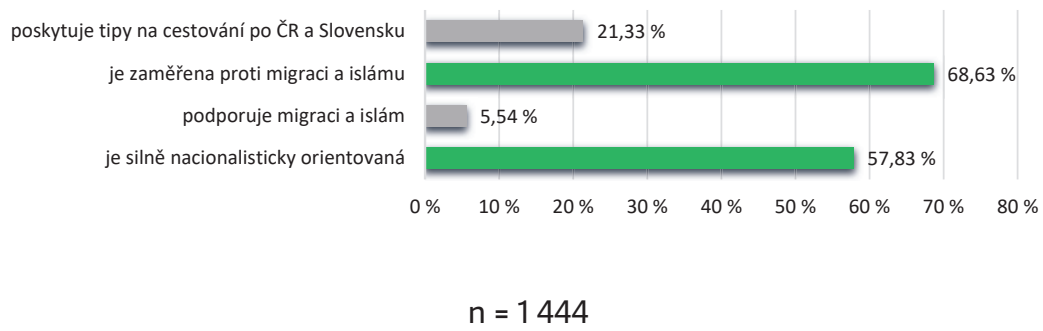

Graf č. 29 Dezinformační stránka na Facebooku - správné a chybné odpovědi

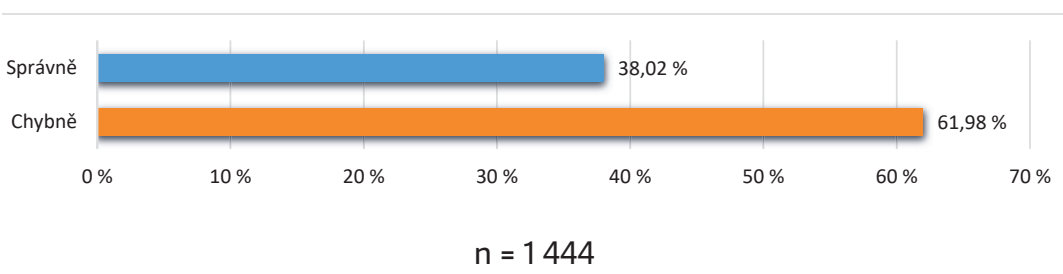

Správně na tuto položku odpovědělo 38,02 \% žáků a chybně 61,98 \% žáků. Více než polovina žáků (68,63 \%) správně poznala, že je stránka zaměřena 
proti migraci a islámu a 57,83 \% žáků určilo, že je stránka silně nacionalisticky orientovaná. Žáků, kteří si myslí, že stránka obsahuje tipy na cestování po Česku a Slovensku, je 21,33 \% a jen velmi malé procento (5,54 \%) žáků se domnívá, že podporuje migraci a islám. Jelikož se jednalo o jednu z otázek, kde bylo více správných odpovědí, ukážeme si na následujícím grafu opět srovnání s dotazníkovou variantou $\mathrm{B}$, ve které je tato položka hodnocena mírněji. $V$ přísněji hodnocené variantě $A$ by žáci obdrželi celkově 546 bodů a v mírnější variantě $B$ by těchto bodů bylo 1081,5.

Graf č. 30 Srovnání variant hodnocení u položky č. 8

Varianta A Varianta B

$$
n=1444
$$

\section{POLOŽKA 9: Jsou žáci schopni určit mediální stereotypy?}

Který z následujících novinových titulků NEOBSAHUJE mediální stereotypy?
A. „Nepřizpůsobiví Romové opět zneužívají sociální dávky!”
B. „Více než polovina dětí ve věku 11-13 let navštěvuje sociální sítě.”
C. „Co muslim, to terorista! Za útoky 11. září 2001 stáli muslimové.”
D. „Otravu pacientky zavinila blond'atá zdravotní sestřička. Omylem zaměnila léky." 
Graf č. 31 Mediální stereotypy - jednotlivé odpovědi

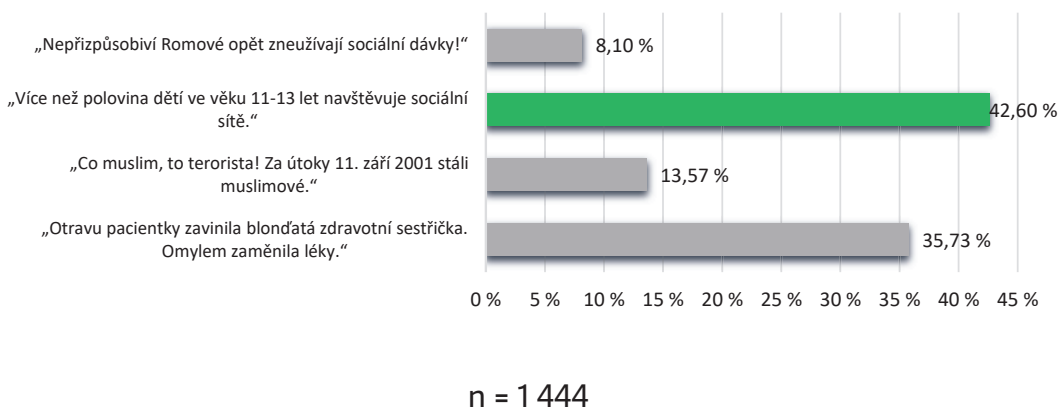

Graf č. 32 Mediální stereotypy - správné a chybné odpovědi

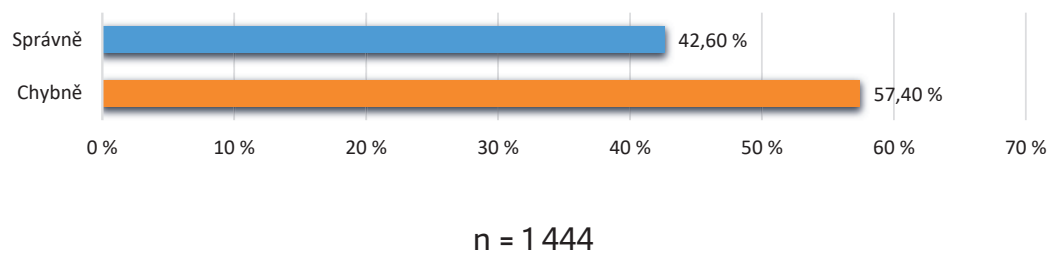

Tato položka obsahuje nejvíce chybných odpovědí v porovnání s ostatními uzavřenými výběrovými položkami, kdy chybně odpovědělo 57,4 \% žáků, z nichž se 35,73 \% domnívá, že mediální stereotyp není obsažen v novinovém titulku zdůrazňujícím, že sestřička, která otrávila pacienta, je blondýna. Dalších 13,57 \% žáků za mediální stereotyp nepovažuje titulek informující o 1l. září v souvislosti s tím, že každý muslim je terorista. Zbylých 8,10 \% zvolilo za titulek neobsahující mediální stereotypy ten, který Romy označuje jako nepřizpůsobivé občany, kteří zneužívají sociální dávky. Správně na položku odpověděla méně než polovina žáků (42,6 \%), která správně označila za titulek neobsahující stereotypy ten, který informuje o dětech využívajících sociální sítě. 
POLOŽKA 10: Jsou žáci schopni poznat zavádějící či zkreslenou zprávu objevující se na zpravodajském internetovém portále?

Na zpravodajském portálu euRABIA se objevila tato zpráva. Co je na ní zavádějící či problematické? (pozn. více správných odpovědí):

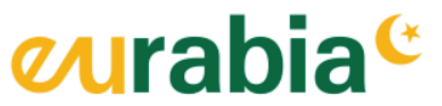

Stř̌eda 18. března 2020. Svátek má Eduard. 9:54:38

Hledej

C Kdo jsme C Redakce C Partneñ C Odkazy C Podpořte nás c Vydavatel C Napište nám

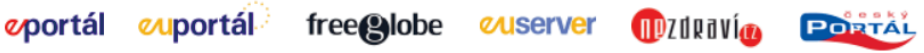

mučedniky má korán prĭpraveny panenské hurisky nepomíjivé krásy a mládí; po každém koitu znovu nabydou panenství. Pro

Německá vláda ukradla respirátory ČR, SR, Švýcarsku a Mad’arsku. At’ si všichni pochcípají, hlavně když přežijí Němci je politika Berlína

Autor: Lukáš Lhot'an | Publikováno: 15.3.2020|Rubrika: Aktuality @ Doporučit 6,9 tis.

Německá vláda sprostě ukradla zásilku respirátoru a roušek, které přes jeji
území převáželi do Rakouska, Švýcarska, Slovenska, Mad'arska a také k nám do
České republiky. Německá kancléřka Merkelová k tomu řekla, že:. "Chceme (my
Němci) jen zajistit, aby lékařské materiály byly ve správných rukou."

Zásilky si v zahraničí objednaly a zaplatily vlády jmenovaných zemí. Od výrobců byly přepravovány přes německé území z důvodu logistiky. Ovšem německá vláda v zoufale situaci, kdy sama posrala co mohla a nemá roušky s respirátory pro své občany, se rozhodla, že okrade okolní země, protože at’ si pochcipají Mad’aři, Slováci či Češi, hlavně když přežijí Němci!Tohle je celá podstata EU, všichni jsme nuly a vládnou nám nadlidé z Německa ...

\section{Obrázek 7 Dezinformační portál}
A. zpráva je uvedena na dezinformačním portálu
B. zpráva obsahuje osobní údaje autora (jméno a prríjmení)
C. zpráva je zkreslená a její motivacíje vyvolat odpor $k$ EU

Komentář: Tato ukázka obsahuje několik znaků typických pro zkreslenou či zavádějící zprávu, která má za cíl vyvolat ve čtenáři určité emoce. V tomto případě jde o emoci strachu ze smrti, kdy nám hrozí nějaké nebezpečí, kterým je koronavirus, tudíž zpráva opět vychází z kulturního kontextu (vznikla na začátku pandemie koronaviru). Typické je také hledání nepř́itele, který může za všechny problémy, čímž se autoři podobných zpráv snaží vyvolat strach a nenávist směřující $\mathrm{k}$ tomuto domnělému nepříteli, $v$ této ukázce je jím EU a Německo v čele s Angelou Merkelovou. Nepřitel v této podobě se vyskytuje i v podobných zprávách nacházejících se na dezinfor- 
mačních webech. V této ukázce se také objevují vulgarismy a generalizace („Všichni jsme nuly a vládnou nám nadlidé z Německa“).

Graf č. 33 Zkreslená zpráva na zpravodajském internetovém portálu jednotlivé odpovědi

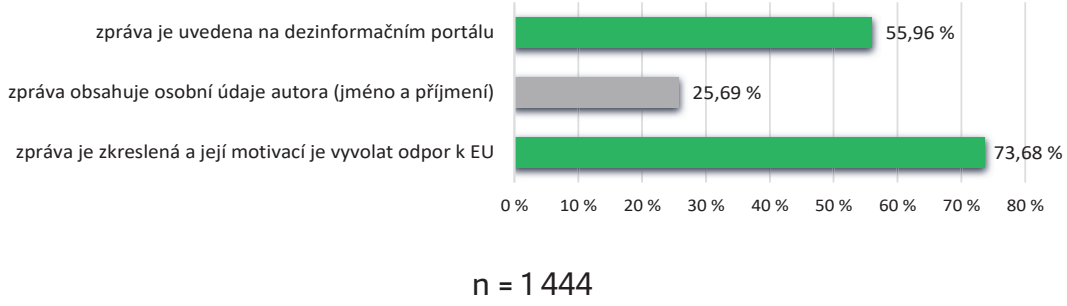

Graf č.34 Zkreslená zpráva na zpravodajském internetovém portálu správné a chybné odpovědi

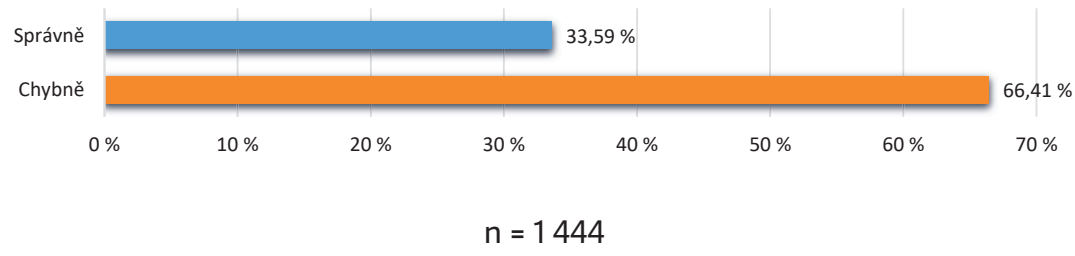

Obě správné odpovědi uvedlo 33,59 \% respondentů, chybně jich odpovědělo $66,41 \%$. Relativně vysoké procento respondentů $(73,68 \%)$ uvedlo, že je zpráva zkreslená a její motivací je vyvolat odpor k EU, 55,96 \% si myslí, že zpráva byla uvedena na dezinformačním portálu. Chybnou odpověd', tedy že zpráva je problematická, protože obsahuje osobní údaje autora, uvedlo 25,69 \% respondentů. Na následujícím grafu opět pro srovnání ukazujeme počet bodů, které by žáci obdrželi, kdyby byli hodnoceni podle dotazníkové varianty B.

Graf č. 35 Srovnání variant hodnocení u položky č. 10

$$
n=1444
$$




\section{POLOŽKA 11: Rozeznají žáci sexismus v reklamách?}

Co mají tyto tři reklamy společné?
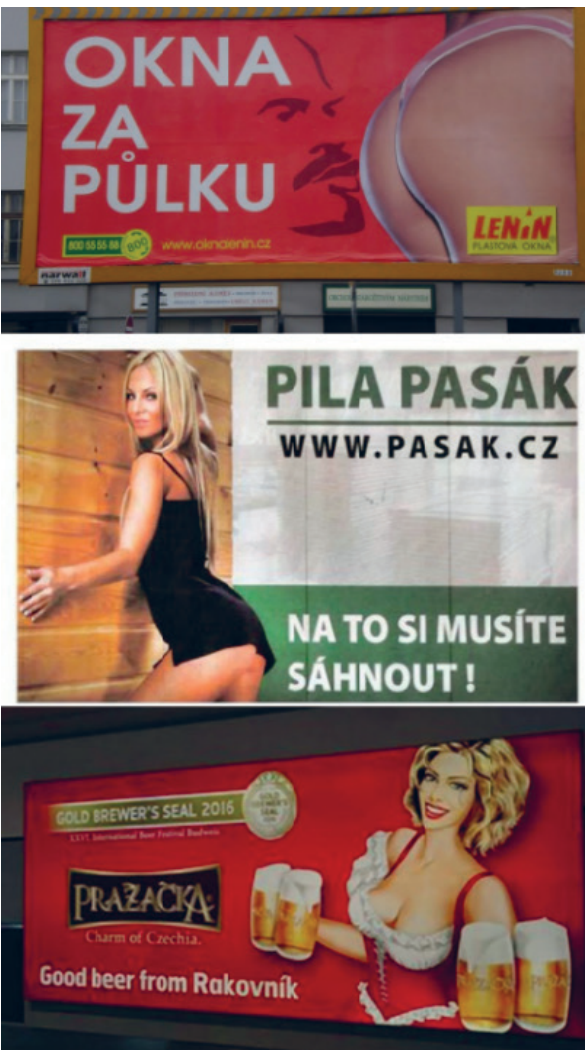

Obrázek 8 Sexismus v reklamách

A. reklamy obsahují produkty, které jsou určeny jen pro ženy

B. reklamy obsahují produkty, které jsou určeny jen pro muže

C. reklamy využívají ženské tělo $\mathrm{k}$ prodeji produktů, které s ženským tělem nesouvisí

D. reklamy obsahuji produkty, které jsou vhodné pouze pro osoby starší 18 let 
Graf č. 36 Sexismus v reklamách - jednotlivé odpovědi

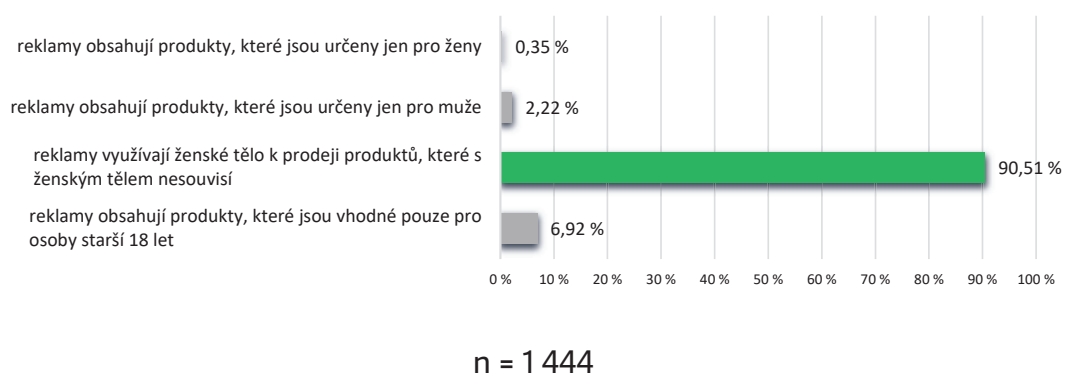

Grafč. 37 Sexismus v reklamách - správné a chybné odpovědi

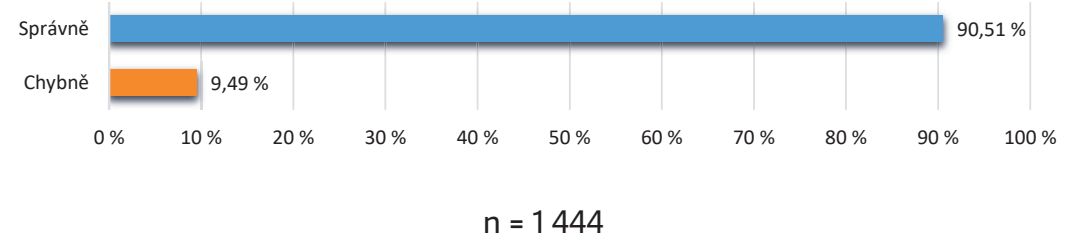

Správně na otázku odpověděla valná většina žáků (90,51 \%), kteří určili, že výše zmíněné reklamy využívají ženské tělo k prodeji produktů, které s ženským tělem nesouvisejí. Chybně odpovědělo pouhých 9,49 \% žáků, z nichž si 6,92 \% myslelo, že reklamy obsahují produkty, které jsou vhodné pouze pro osoby starší 18 let; 2,88 \% žáků si myslí, že reklamy obsahují produkty určené pouze pro ženy a 0,35 \% žáků se domnívá, že reklamy obsahují produkty určené pouze pro ženy. 
Autorem tohoto článku je „ČTK". Co to znamená?

\section{BMW kvůli koronaviru na čtyři týdny zastaví výrobu v Evropě}

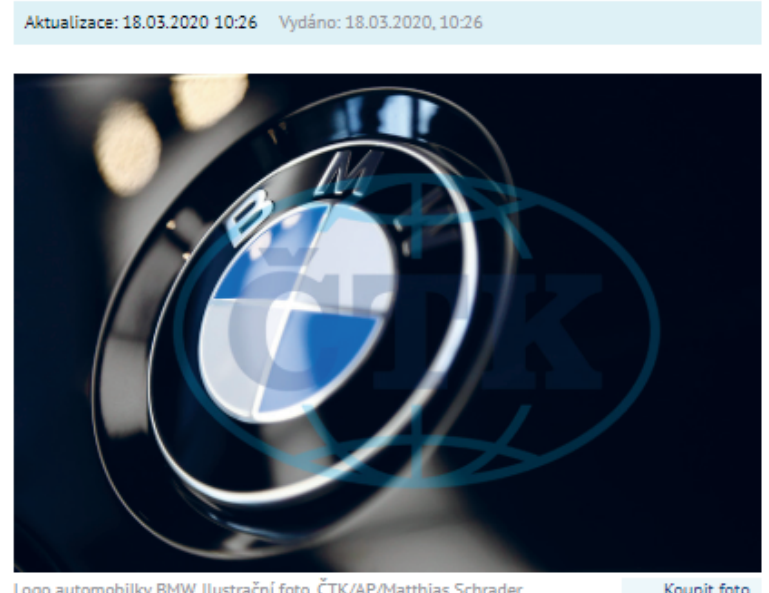

Berlín - Německá automobilka BMW kvůli koronaviru na více než čtyrĭi týdny zastaví výrobu ve všech svých evropských závodech. Informoval o tom dnes šéf podniku Oliver Zipse. BMW tak učinila podobný krok jako automobilový koncern Volkswagen, který své evropské závody, včetně těch českých, uzavírá na dva až tři týdny.

"Ode dneška uzaviráme naše evropské automobilové závody a závod Rosslyn v Jihoafrické republice. Přerušení produkce je zatím plánováno do 19. dubna," řekl Zipse $\checkmark$ Mnichovè.

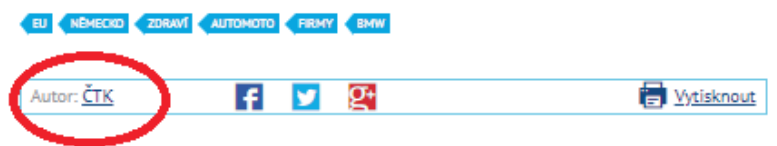

Obrázek 9 Zkratka ČTK
A. jedná se o iniciály autora článku
B. jedná se o zkratku pro Českou tiskovou kancelár̆
C. jedná se o zkratku pro český televizní kanál 
Graf č. 38 Zkratka "ČTK" - jednotlivé odpovědi

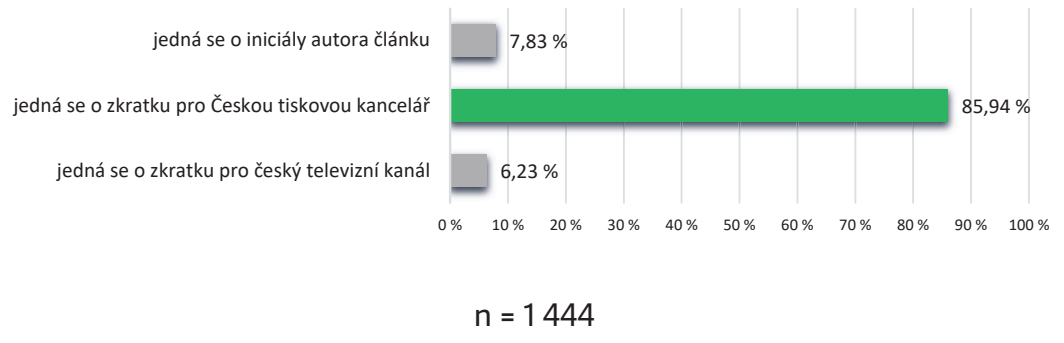

Graf č. 39 Zkratka „ČTK" - správné a chybné odpovědi

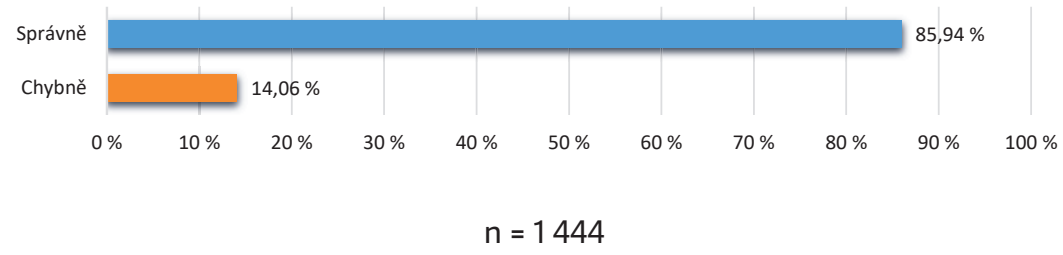

Na položku správně odpovědělo 85,94 \% respondentů, kteří určili, že zkratka „ČTK“ znamená Česká tisková kancelář. Chybně jich odpovědělo 14,06 \%, přičemž 6,23 \% z nich uvádí, že "ČTK“ je zkratkou pro český televizní kanál, a 7,83 \% uvádí, že jde o iniciály autora článku. 
Tento př́spěvek na svém instagramovém účtu sdílela jedna populární blogerka. Co znamená hashtag \#ad dole v popisku?
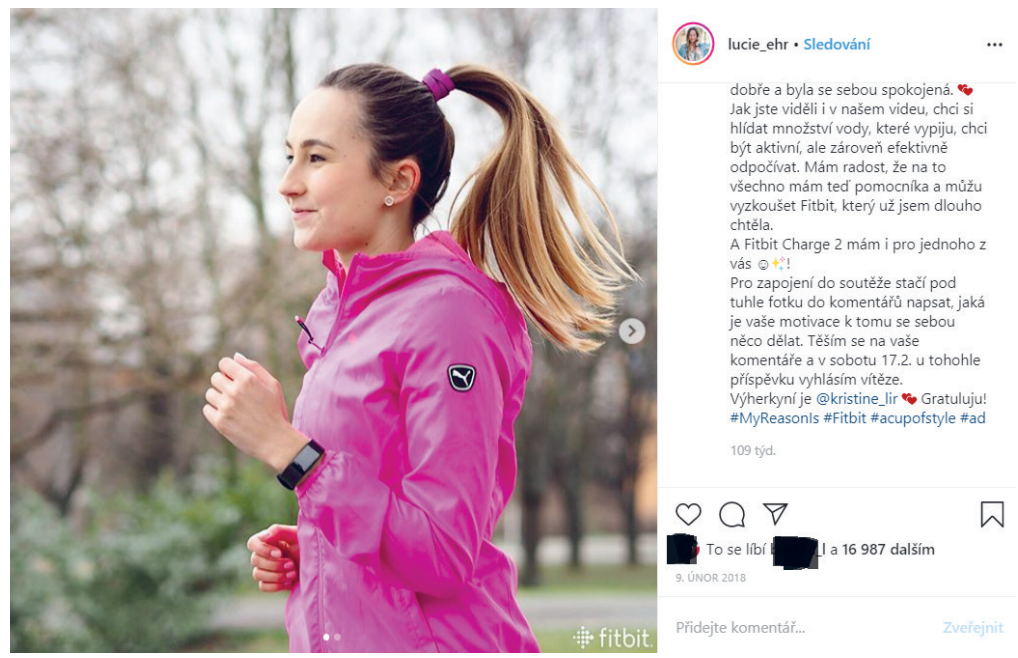

Obrázek 10 Reklama na sociálních sítích
A. hashtag \#ad je speciální instagramová zkratka pro „atd.”
B. hashtag \#ad upozorňuje na to, že daný příspěvek obsahuje více fotek
C. hashtag \#ad znamená, že příspěvek obsahuje reklamu na nějaký produkt

Graf č. 40 Hashtag \#ad-jednotlivé odpovědi

hashtag \#ad je speciální instagramová zkratka pro „atd.“

hashtag \#ad upozorňuje na to, že daný príspěvek obsahuje více fotek

hashtag \#ad znamená, že příspěvek obsahuje reklamu na nějaký produkt

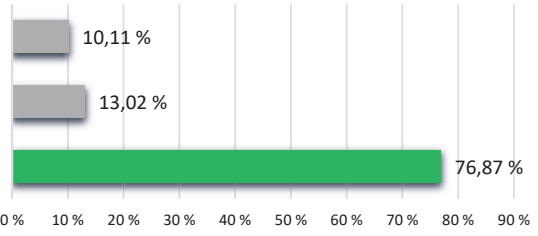

$n=1444$ 
Graf č. 41 Hashtag \#ad - správné a chybné odpovědi

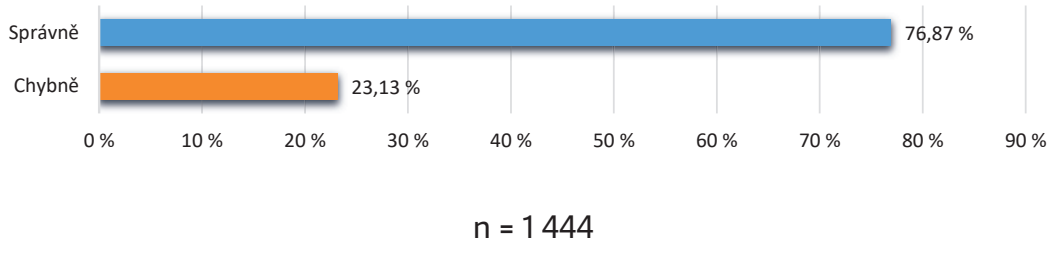

Správně odpovědělo 76,87 \% žáků, kteří uvádějí, že hashtag \#ad znamená, že příspěvek obsahuje reklamu na určitý produkt. Chybně odpovědělo 23,13 \% žáků, z nichž si 10,11 \% myslí, že hashtag \#ad je speciální instagramová značka pro „atd.“, a 13,02 \% se domnívá, že hashtag \#ad má upozorňovat na to, že příspěvek obsahuje více fotek. 
Který z twitterových příspěvků skutečně napsal premiér ČR Andrej Babiš?

\section{Andrej Babiš}

@AndreiBabis

Ahoj lidi, rozhodl jsem se podat rezignaci na funkci předsedy vlády do rukou prezidenta republiky.

Translate Tweet

8:55 AM · Dec 14, 2018 · Twitter Web Client

1 Like

\section{Andrej Babiš}

@AndrejBabis

Žádám zaměstnavatele, aby se postavili $k$ této situaci čelem, uznali zaměstnancủm překážku v práci, dali jim plnou mzdu a umožnili jim pracovat na home office, pokud je to možné.

Translate Tweet

10:10 AM - Mar 6, 2020 - Twitter for iPhone

21 Retweets $\mathbf{2 0 3}$ Likes

Obrázek 11 Andrej Babiš (Twitter)
A. př́spěvek ve fialovém rámečku
$B$. př́spěvek $v$ červeném rámečku
C. oba dva

Komentář: $V$ této položce je několik znaků, kterém nám napovídají, že je twitterový profil ve fialovém rámečku falešný. Často se setkáváme s tím, že 
profil sice na první pohled nese skutečnéjméno daného člověka, avšak když se podíváme na jméno, co je za zavináčem, můžeme narazit na nesrovnalosti (v tomto př́ipadě jde o zkomoleninu jména, která má podobu @AndreiBabis místo správné podoby @AndrejBabis, další falešný účet tohoto politika má název @AndrejBabiis, @a_babis apod.).Dalším znakem, který je typický pro falešné profily i na jiných sociálních sítích, je počet uživatelů sledujících daný profil. S tím souvisí i to, kolik uživatelů dané příspěvky na profilu komentuje, kolika uživatelům se příspěvky líbí a kolik uživatelů je sdílí. V námi vybraném příspěvku, nacházejícím se na falešném profilu, se tento příspěvek líbil jen jednomu člověku a nikdo jej nesdílel. Vzhledem k obsahu příspěvku, který je sám o sobě velmi zavádějící, je to pochybné. Samotné oslovení „Ahoj lidi..." a následné sdělení o rezignaci vypadá dost nepřesvědčivě a je nepravděpodobné, že by premiér o takovém kroku informoval veřejnost podobným způsobem.

Graf č. 42 Falešný twitterový účet - jednotlivé odpovědi

$$
n=1444
$$

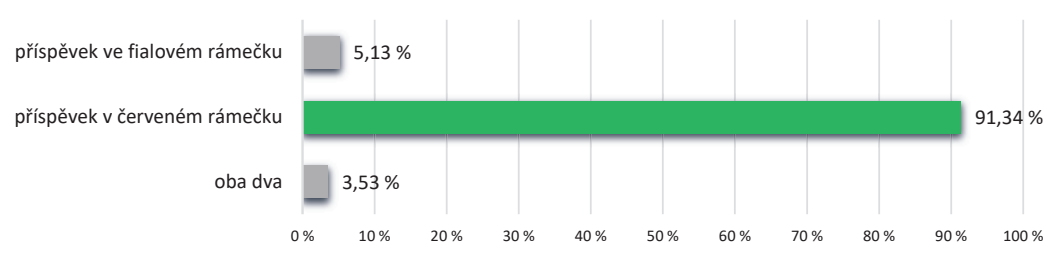

Graf č. 43 Falešný twitterový účet - správné a chybné odpovědi

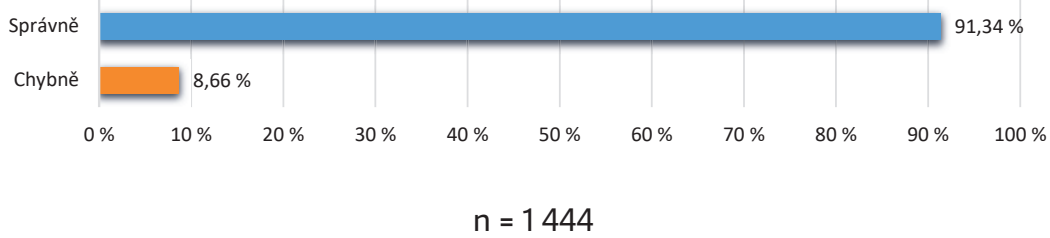

Jedná se opět o položku, na kterou naprostá většina žáků (91,34 \%) odpověděla správně, tedy že skutečný twitterový účet premiéra Andreje Babiše je ten v červeném rámečku. Chybně odpovědělo 8,66 \%, 5,13 \% za skutečný účet považuje ten v červeném rámečku a 3,53 \% si myslí, že oba účty jsou opravdové. 
Můžete si na internetu založit vlastní zpravodajský web a sdílet na něm vědomě nepravdivé zprávy (např. Skupina cikánů brutálně napadla maminku s malým dítětem)?
A. ANO, ale můžeme být obviněni z trestného činu „„šíření poplašné zprávy", „,podněcování k nenávisti“" apod.
B. NE, nemůžeme. Musíme mít vystudovanou žurnalistiku a novinářskou licenci.
C. ANO, žijeme v demokratické společnosti a na internetu máme bez- meznou svobodu projevu.

Graf č. 44 Vědomé šíření nepravdivých zpráv-jednotlivé odpovědi

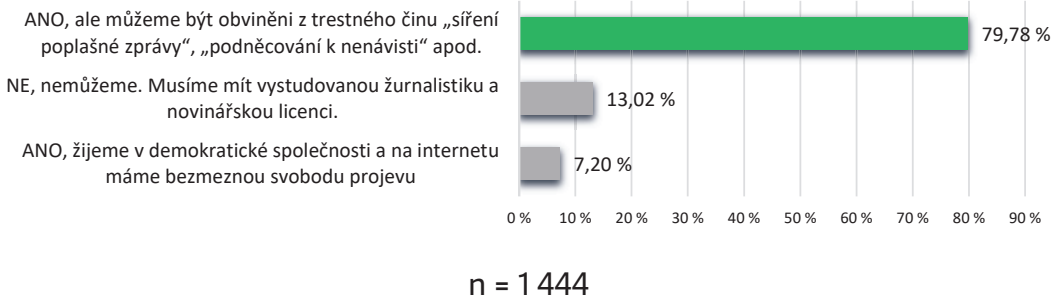

Graf č. 45 Vědomé šiření nepravdivých zpráv - správné a chybné odpovědi

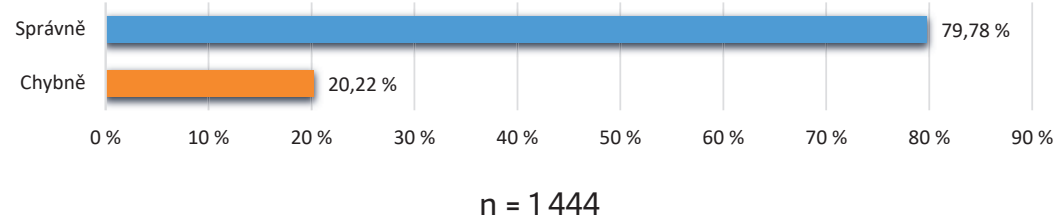

Správnouodpověd',tedyžeza podobnéčiny můžemebýt odsouzeniz trestného činu, uvedlo 79,78 \% žáků. Chybně odpovědělo 20,22 \% žáků, přičemž 13,02 \% z nich simyslí,žeabychom mohlizakládat podobnéwebya psát na nichzprávy, musíme mít vystudovanou žurnalistiku;7,2 \% z nich sedomnívá,žemámebezmeznou svobodu projevu, a proto podobné zprávy vytvářet můžeme. 
POLOŽKA 16: Rozeznají žáci upravenou fotografii na internetu?

Na této fotografii můžete vidět kočku Snowball se svým majitelem. Je fotografie skutečná, nebo upravená?

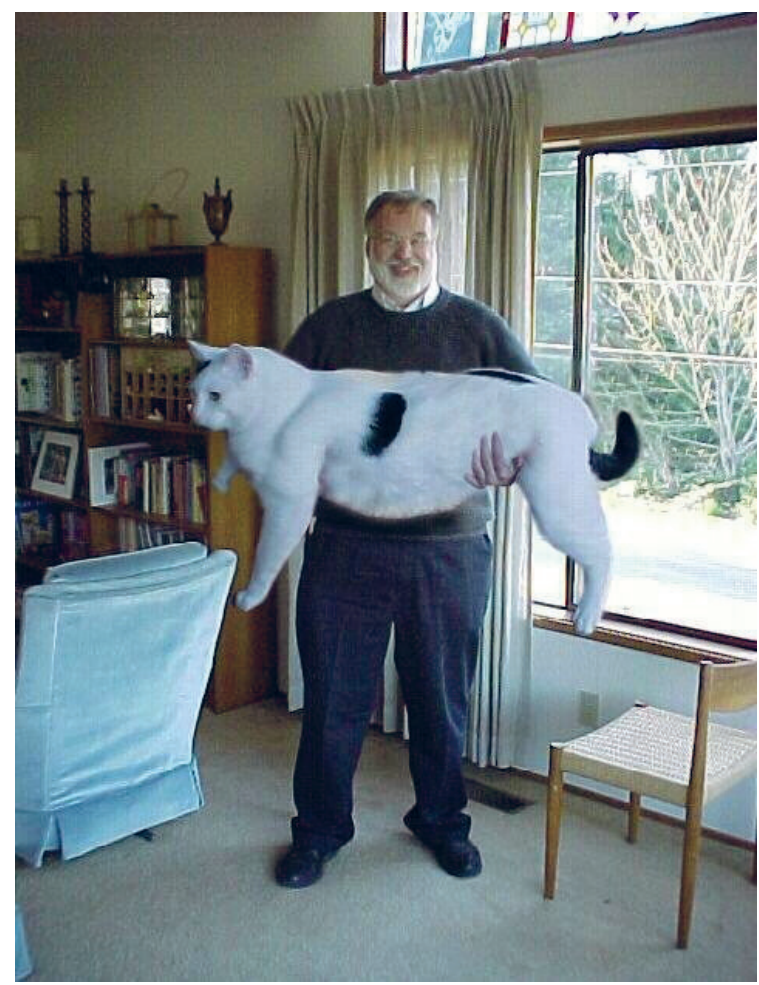

Obrázek 12 Kočka Snowball

A. fotografie je skutečná

B. fotografie je upravená

Komentár̆: V dotazníku měli žáci tuto fotografii ve větším rozlišení, a pokud se dívali pozorně, tak poznali, že kočka je do fotografie přidána uměle pomocí některého z programů na úpravu fotek. Nejlepším ukazatelem byla ruka majitele, která drží kočku v zadní části těla. 
Graf č. 46 Falešná fotografie -jednotlivé odpovědi

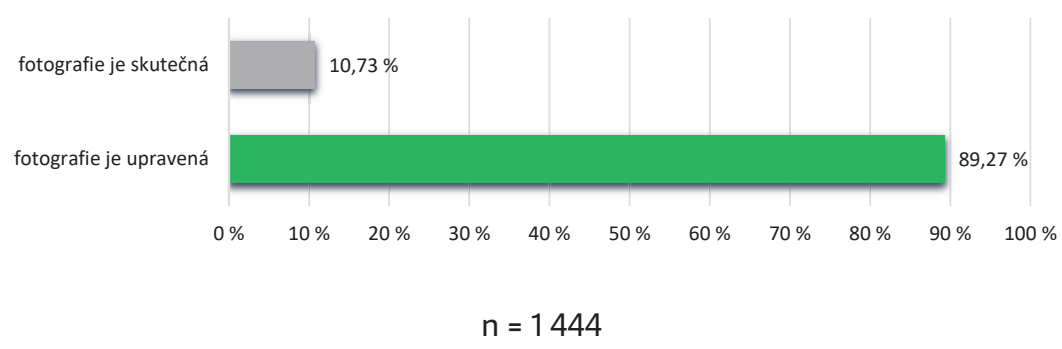

Graf č. 47 Falešná fotografie - správné a chybné odpovědi

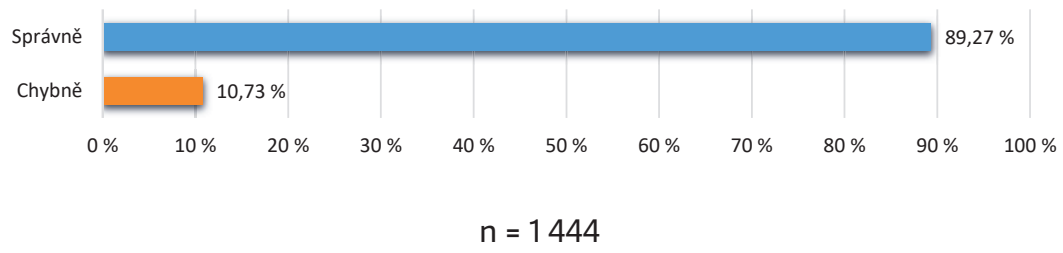

Většina žáků (89,27 \%) správně poznala upravenou fotografii a 10,73 \% žáků se mylně domnívalo, že je fotografie skutečná. 
Co je úkolem tzv. „internetových trollů“?

A. jejich úkolem je vytvářet falešné profily, na které si místo profilové fotografie dávají obrázky trollů

B. jejich úkolem je vytvářet smyšlené fantasy př́běhy na tzv. „fanfiction“ stránkách

C. jejich úkolem je šíritit na internetu nenávistné, urážlivé nebo nesouvisející príspěvky

Grafč. 48 Internetový „troll“ - jednotlivé odpovědi

jejich úkolem je vytvářet falešné profily, na které si místo profilové fotografie dávají obrázky trollů

jejich úkolem je vytvářet smyšlená fantasy př́běhy na tzv. „fanfiction“ stránkách

jejich úkolem je šriřit na internetu nenávistné, urážlivé nebo nesouvisející příspěvky

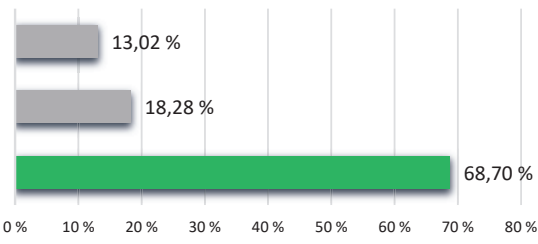

$n=1444$

Graf č. 49 Internetový „troll” - správné a chybné odpovědi

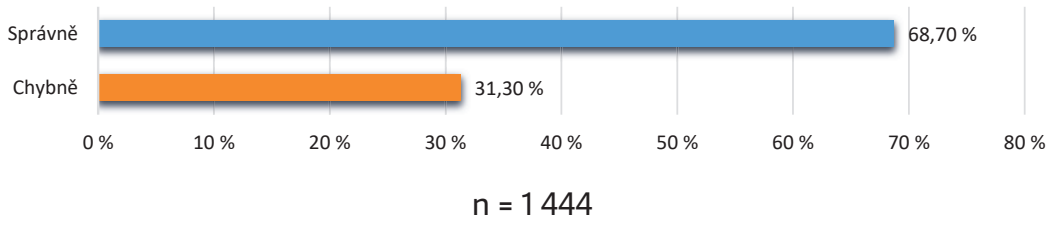

Podle 68,70 \% žáků je úkolem internetových „trollư ššřit nenávistné, urážlivé či nesouvisející příspěvky, tudíž na otázku zodpověděli tito žáci správně. Chybně odpovědělo 31,3 \% žáků, z nichž 13,02 \% uvádí, že internetoví „trollové" si vytvářejí falešné účty s profilovými fotografiemi trollů, a 18,28 \% si myslí, že tito "trollové“ píší smyšlené fantasy příběhy na fanfiction stránky (stránky obsahující fiktivní príběhy, které tvoří fanoušci určitých knih, filmů apod.). 
POLOŽKA 18: Poznají žáci nesouvisející spojení fotografie a citátu?

Je Albert Einstein autorem tohoto citátu?

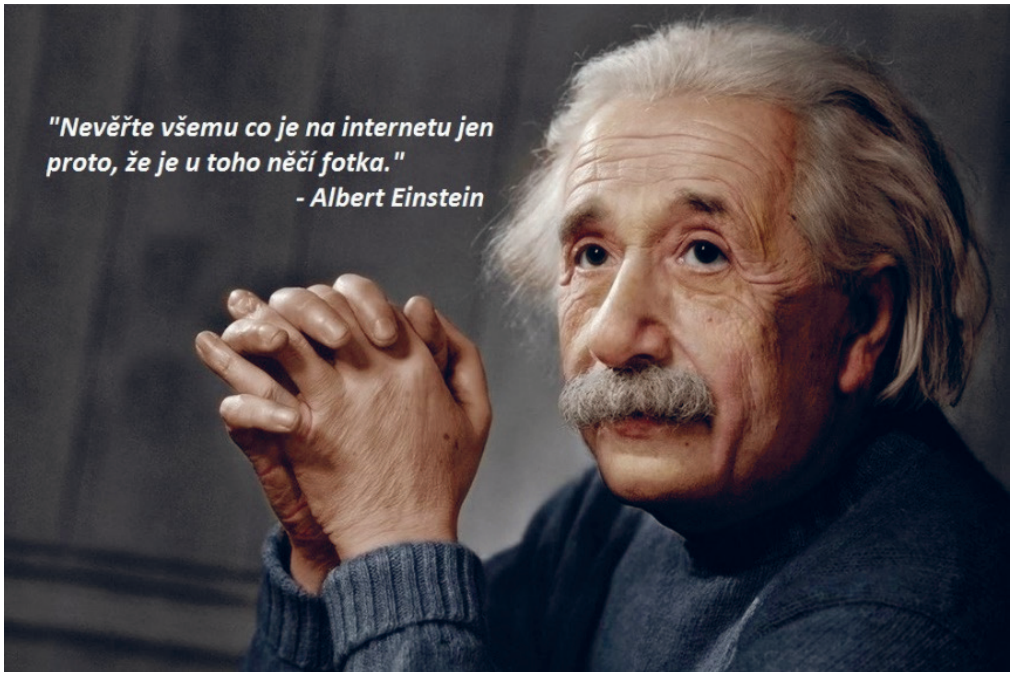

Obrázek 13 Citát
A. ANO
B. NE

Komentár̆: Albert Einstein nemohl být autorem tohoto citátu $\mathrm{z}$ toho důvodu, že v době, kdy žil (1879-1955), internet neexistoval (ten existuje v podobě, jakou dnes známe, až od 9o. let 20. století). Spojení určité známé osobnosti s citátem, který tato osobnost nikdy neřekla, slouží k podpoření důvěryhodnosti a naléhavosti daného citátu. 
Graf č.50 Nesouvisející spojení fotografie a citátu -jednotlivé odpovědi

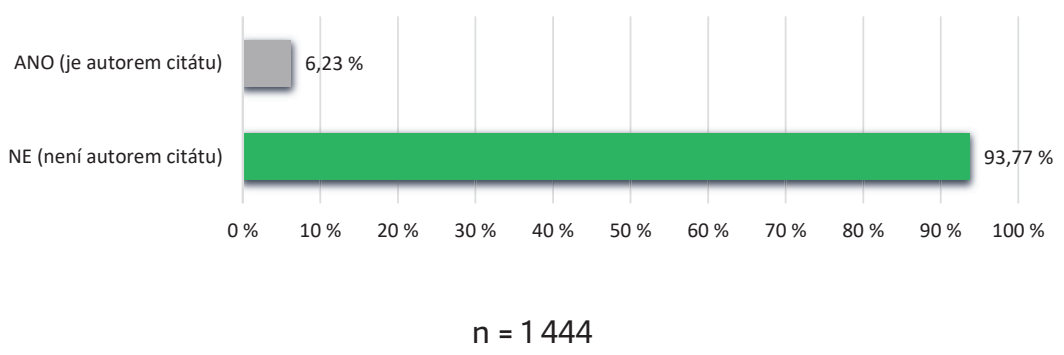

Grafč. 51 Nesouvisející spojení fotografie a citátu - správné a chybné odpovědi

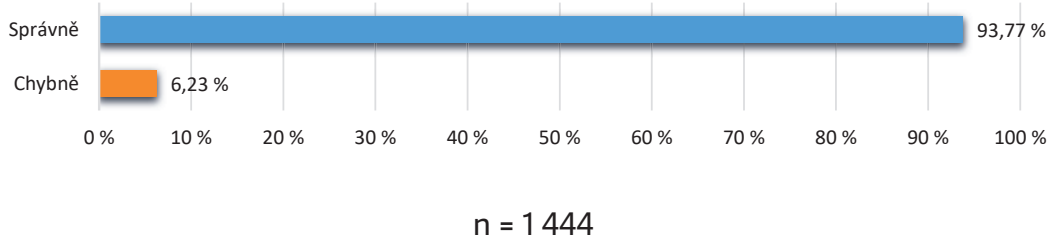

Naprostá většina žáků (93,77 \%) správně zvolila, že Albert Einstein není autorem výše zmíněného citátu, zatímco 6,23 \% žáků se mylně domnívá, že Albert Einstein je opravdu autorem daného citátu. 
O odchodu prince Harryho a jeho manželky Meghan z britské královské rodiny informovala mnohá média. Kterým z novinových titulků o tom informoval bulvární web „Aha!"?
A. „Harry a Meghan opět na scéně. Odchod z královské rodiny se blíži.”
B. „Princ Harry a jeho manželka se vzdávají role v britské královské rodině. Palác rozhodnutím zaskočili."
C. „MEGXIT: Za vším hledej ženu a ... Prachy!”

Komentář: V tomto novinovém titulku („MEGXIT: Za vším hledej ženu a ... Prachy!") jsou znaky bulváru velmi zřetelné: snaha o senzaci, generalizování, zjednodušování, zveličování, úderné a krátké sdělení, působení na pudové emoce a snaha vzbudit ve čtenár̆i zvědavost. Podobné prvky využívají také fake news.

Graf č. 52 Komunikační styl bulváru - jednotlivé odpovědi

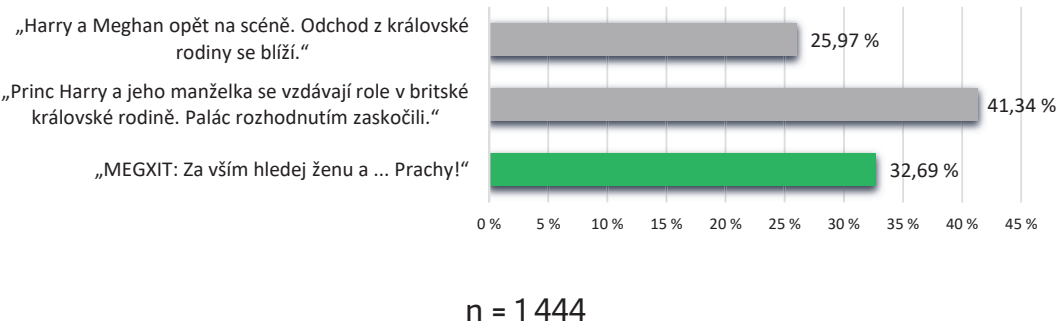

Graf č.53 Komunikační styl bulváru - správné a chybné odpovědi

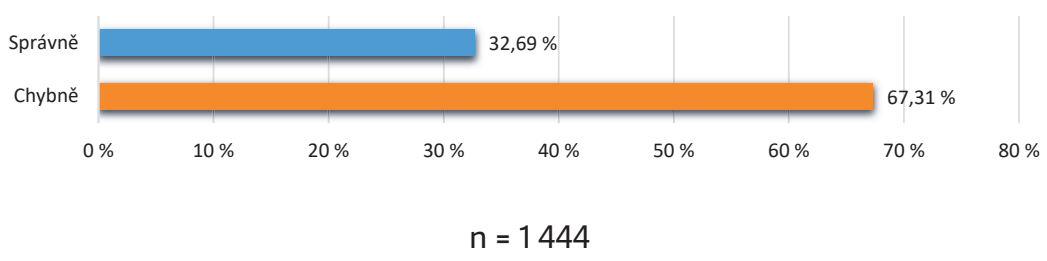


Na tuto otázku odpověděla správně pouhá třetina žáků (32,69 \%), kteří novinový titulek „MEGXIT: Za vším hledej ženu a ... Prachy!“ správně označili za bulvární. Chybně odpovědělo 67,31 \% žáků, z nichž 25,97 \% označilo za bulvární titulek „Harry a Meghan opět na scéně. Odchod z královské rodiny se bliží.“ a 41,34 \% označilo titulek „Princ Harry a jeho manželka se vzdávají role v britské královské rodině. Palác rozhodnutím zaskočili.“ 
POLOŽKA 20: Jsou žáci schopni rozeznat hoax a s ním související upravenou fotografii?

Autor tohoto facebookového príspěvku informuje o tom, že se v Chebu na vlakovém nádraží vyskytuje velká skupina migrantů. Je podle vás př́spěvek pravdivý, nebo nepravdivý?

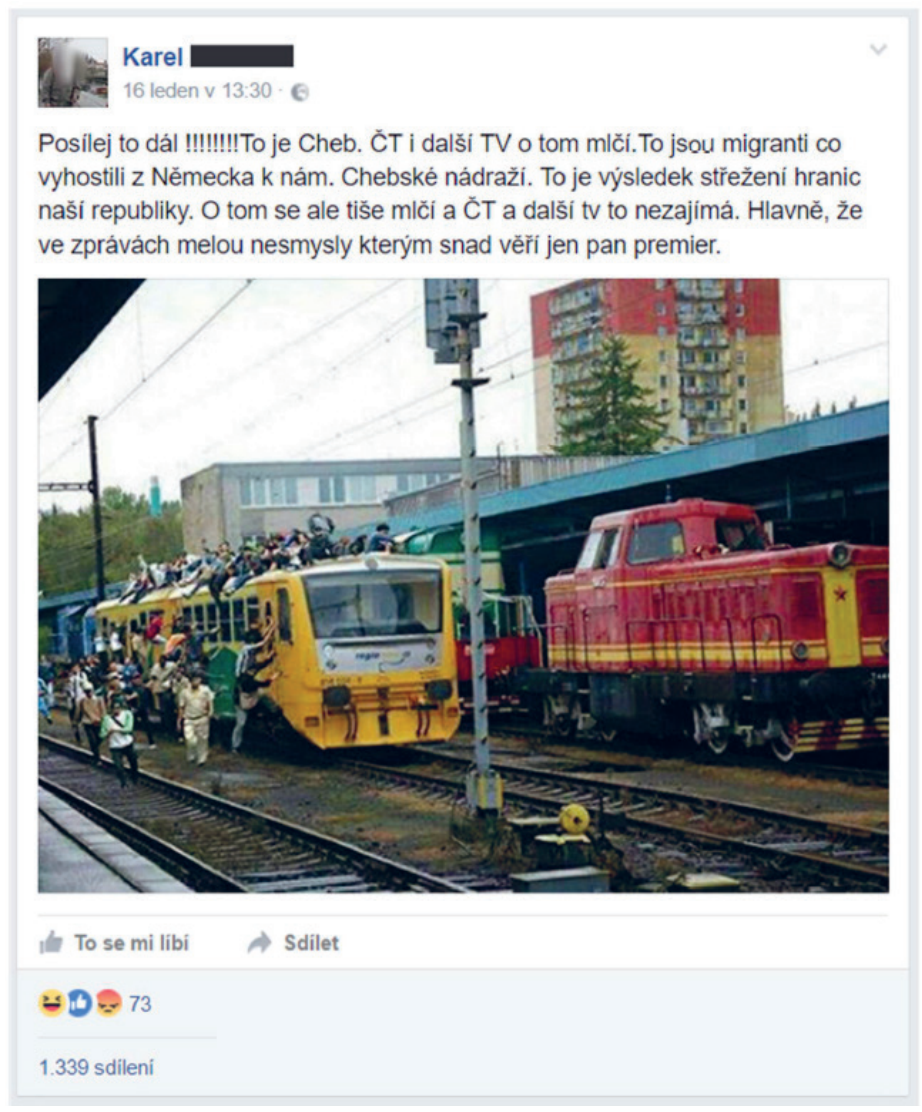

Obrázek 14 Dezinformace Cheb
A. př́spěvek je pravdivý
B. př́spěvek je nepravdivý 
Komentář: Podrobněji jsme se znaky hoaxů zabývali již v první položce. Tento hoax obsahuje znaky velmi podobné, proto je zde popíšeme jen stručně. Výše zmíněný hoax obsahuje apel na sdílení, který je doplněn množstvím vykřičníků (,...Posílej to dál!!!!!"). Jeho cílem je vzbudit emoce, a to konkrétně emoci strachu $\mathrm{z}$ migrantů (tematika migrantů, migrace, islámu se v hoaxech objevuje často), tudíž souvisí s problémy, které ve společnosti rezonují. Dalším znakem je také apel na to, že nám někdo něco tají (,....o tom se ale tiše mlčí a ČT a dalši TV to nezajímá.") a podrývání důvěry v tradiční média (,...ve zprávách melou nesmysly..."). Tento hoax je dále doplněn fotografií (lze lépe poznat ve vyšším rozlišení). Jedná se však o fotomontáž, ve které byla spojena fotka českého vlaku s fotkou pocházející z Indonésie, na které jsou zachyceni lidé jedoucí na střeše vlaku.

Graf č.54 Hoax a upravená fotografie - jednotlivé odpovědi

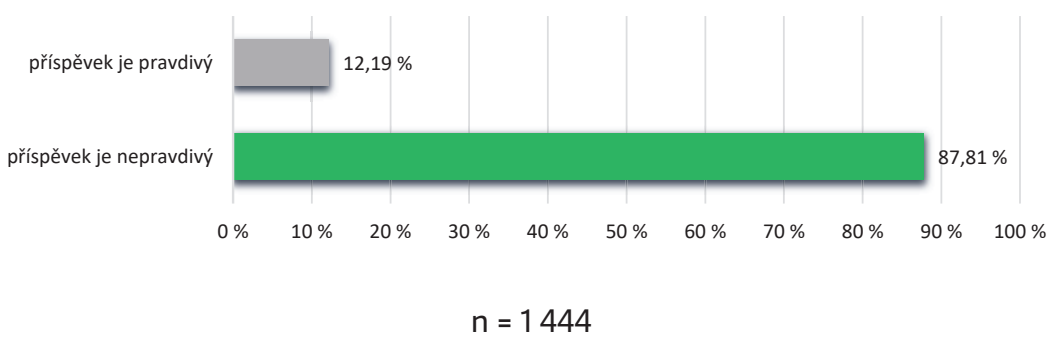

Graf č. 55 Hoax a upravená fotografie - správné a chybné odpovědi

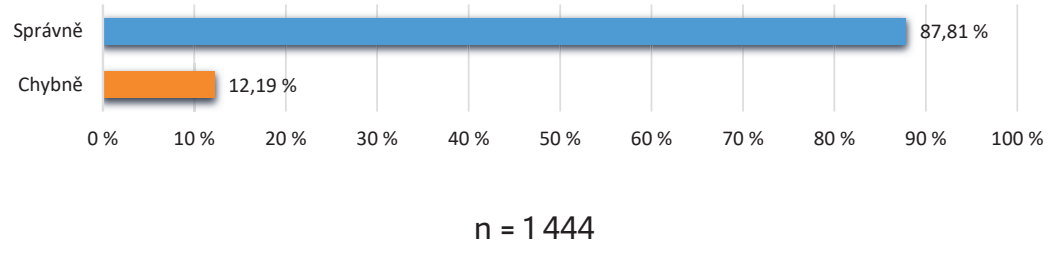

To, že př́íspěvek je nepravdivý, správně poznalo 87,81 \% žáků, zatímco 12,19 \% žáků se mylně domnívalo, že příspěvek je pravdivý. 
V následujícím grafu si shrneme odpovědi na všechny položky dohromady, abychom názorně viděli srovnání správných a chybných odpovědí ve všech položkách 1. části dotazníku.

Graf č.56 Odpovědi na všechny položky

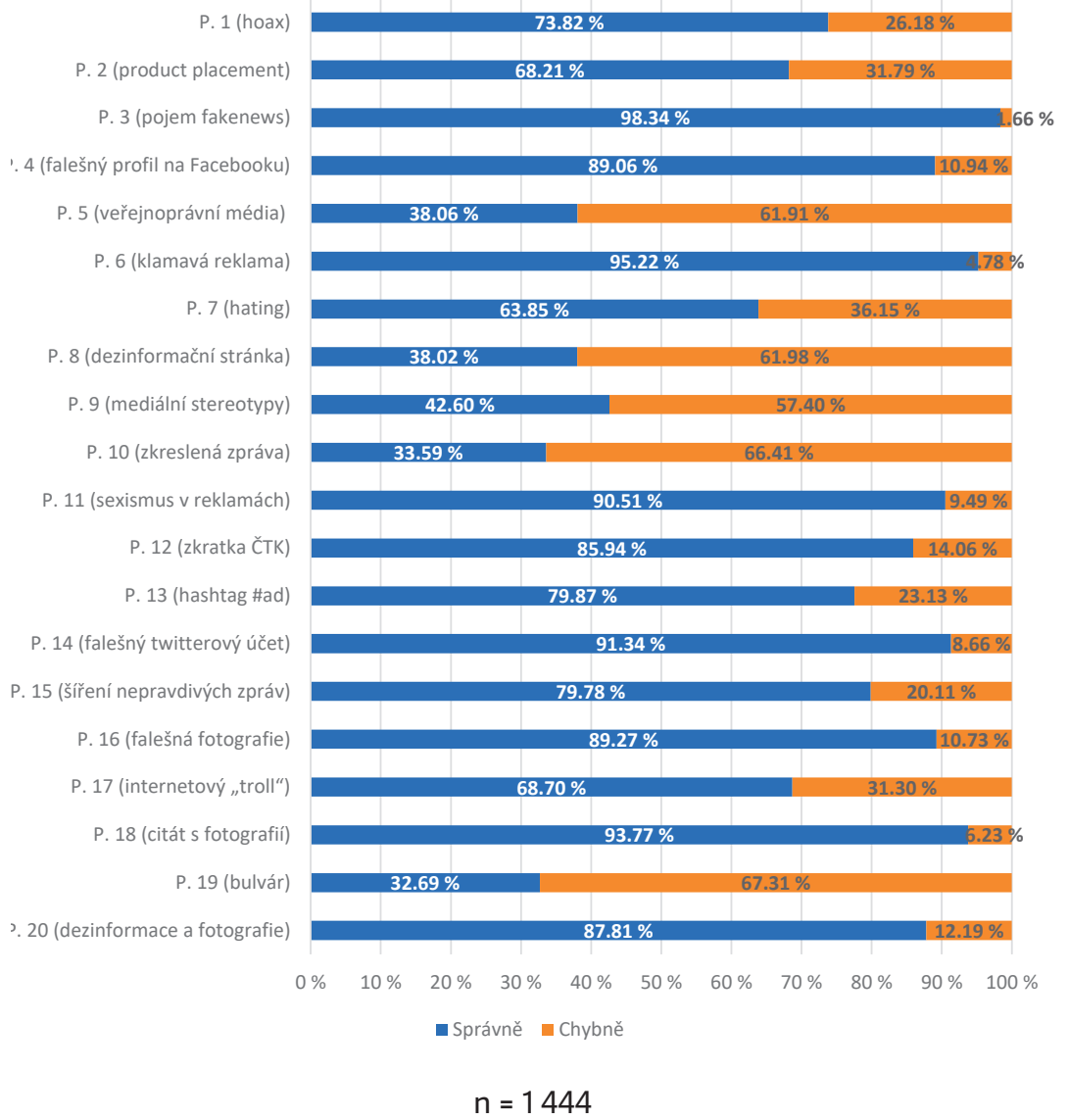

Nejvíce správných odpovědí ( $98,34 \%$ ) bylo zaznamenáno u položky č. 3 , která se zabývala pojmem fake news. Další položkou s nejvíce správnými odpověd'mi (95,22 \%) byla ta s číslem 6, která ukazovala klamavou reklamu na internetu. Hned za ní následuje položka č. 18, která se týkala nesprávného spojení fotografie a citátu a na kterou správně odpovědělo 93,77 \% 
žáků. Další položka s velmi vysokým procentem úspěšnosti byla položka č. 14 (správně 91,34 \%) týkající se falešného twitterového účtu, následuje položka č. 11 (90,51 \%) zabývající se sexismem v reklamách, položka č. 16 (89,27 \%) ukazující falešnou fotografii a položka č. 4 (89,06 \%), u které měli žáci rozeznat falešný facebookový profil. Můžeme zde sledovat, že žáci byli nejúspěšnější v položkách, které měly některé společné faktory (viz kap. 2.3) - rozeznání falešných profilů na sociálních sítích a fotografiích (položka č. 4, 14, 16 a 18), práce s reklamou, a to především odhalení klamavé reklamy a sexismu v reklamách (položka č. 6 a 11) a následně správná interpretace pojmu fake news (položka č. 3).

Naopak nejvíce chybných odpovědí, a to $67,31 \%$, bylo zaznamenáno v položce č. 19, ve které měli žáci určit, který z novinových titulků obsahuje prvky bulváru. Následují další tři položky, jejichž společným znakem je, že jsou výčtové $s$ výběrem neomezeného počtu odpovědí a byly hodnoceny přísněji (viz kap. 2.5.2). Jedná se o položku č. 10 (66,41 \% chybných odpovědí) ukazující zkreslenou zprávu na dezinformačním zpravodajském portále, položku č. 8 (61,98 \%) týkající se dezinformační stránky na Facebooku a položku č. 5 (61,91 \%), ve které měli žáci volit média, která nejsou veřejnoprávní. Poslední položka, na kterou více než polovina (57,40 \%) žáků odpověděla chybně, je ta s číslem 9, ve které měli žáci novinový titulek neobsahující mediální stereotypy. Opět zde můžeme sledovat to, že položky s nejvyšším procentem chybných odpovědí mají společné faktory - položky č. 5 , 9 a 19 se zabývají médii obecně, a to konkrétně mediálními stereotypy, veřejnoprávními médii a komunikačním stylem bulváru, a položky č. 8 a 10, které obě dvě zkoumají schopnost žáků rozeznat dezinformace či dezinformační weby.

Za zmínku stojí také položky (č. 7 a 17) týkající se hatingu. Více než třetina žáků $(36,15 \%)$ se domnívá, že Facebook nenávistné příspěvky smaže (21,88 \%) nebo že máme bezmeznou svobodu, a proto nenávistné příspěvky na internet psát můžeme $(\mathbf{1 4 , 2 7} \%)$. Dále téměř třetina žáků (31,30 \%) netuší, co je úkolem tzv. internetových trollů, kteří maji s hatingem velmi úzkou souvislost. Toto zjištění může být impulzem k zahájení diskuze o hranicích svobody projevu na internetu, která má také přímou spojitost s kyberšikanou. 


\section{Aritmetický průměr počtu bodů v dotazníkové variantě $A$ i B}

Graf č.57 Průměrný počet bodů v obou variantách dotazníku

$$
\mathrm{n}=20
$$

Pro srovnání zde uvádíme aritmetický průměr počtu bodů z obou variant dotazníku. Žáci v obou variantách mohli dosáhnout celkového počtu 20 bodů. Aritmetický průměr počtu bodů $\bar{x}(A)$ v dotazníkové variantě $A$ činí 14 bodů, přičemž směrodatná odchylka je 3 body. Aritmetický průměr počtu bodů $\overline{\mathrm{x}}(\mathrm{B}) \mathrm{v}$ dotazníkové variantě $\mathrm{B}$ činí 15 bodů a směrodatná odchylka je 3 body. Průměrný počet bodů byl počítán z výsledků 1444 žáků.

Grafč.58 Celkové rozdělení bodů

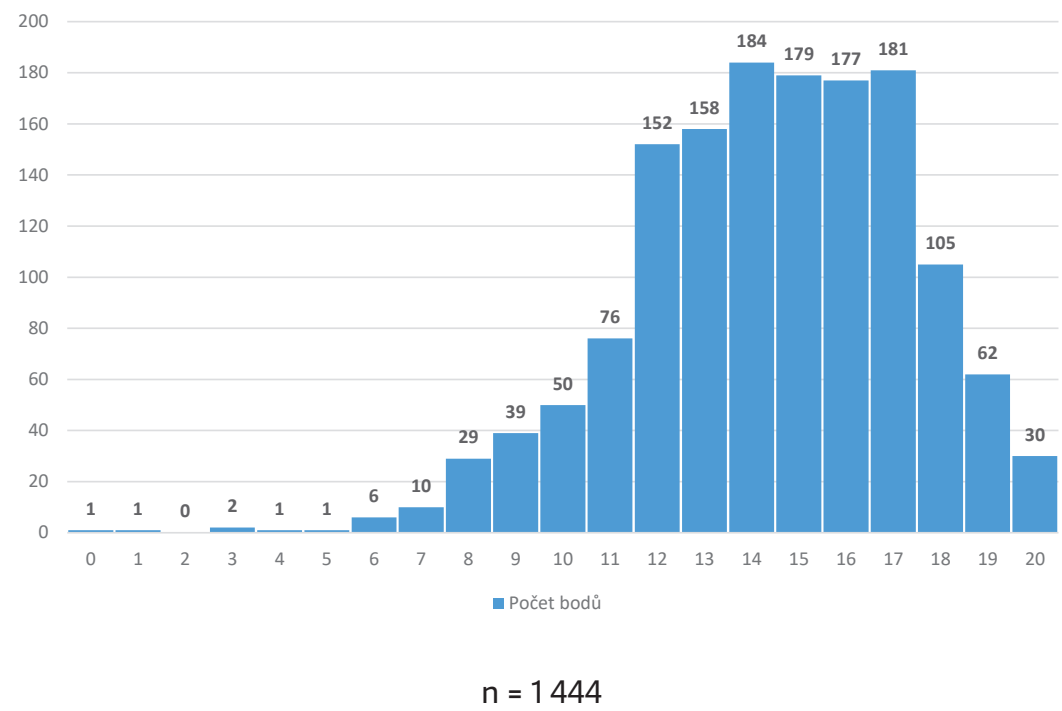

V tomto grafu můžeme vidět četnost jednotlivých bodů, přičemž nejčastěji žáci získali 14 bodů. Téměř polovina respondentů (49,93 \%) měla velmi po- 
dobné výsledky, a to mezi 14 a 17 body (rozdíly mezi četnostmi pro 14, 15, 16 a 17 bodů jsou marginální).

Kumulativní četnost skupin pod 10 bodů je 90 respondentů, což je $6,23 \%$ respondentů. Tudíž alespoň poloviční mediální gramotnost mají skoro všichni respondenti. Zároveň kumulativní četnost skupin pro 19 a 20 bodů je 92 respondentů, tj. výborné výsledky má jen cca 6,37 \% respondentů.

\section{Srovnání chlapců a dívek}

Pro účely této monografie jsme statistické rozdíly v počtu bodů mezi dívkami a chlapci znázornili pomocí krabicového grafu. Stejný graf bude použit i pro srovnání mezi jednotlivými třídami. Autorka se bude statistickými testy podrobněji zabývat ve svojí disertační práci.

Graf č. 59 Srovnání počtu bodů dívek a chlapců

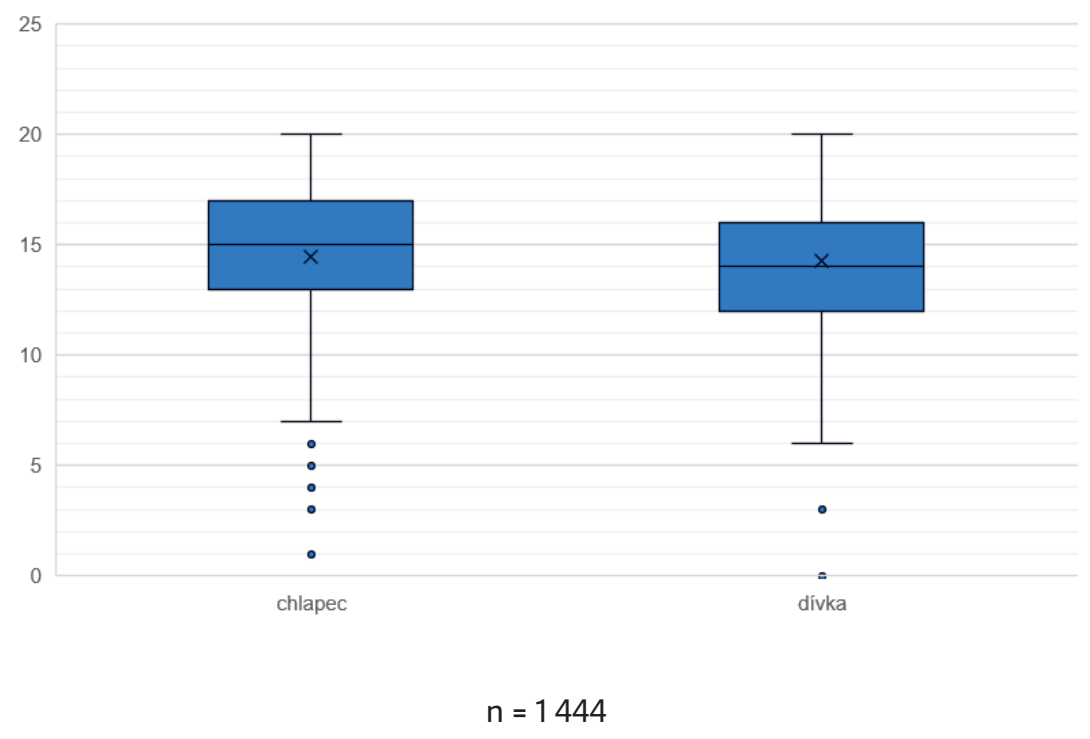

Maximální hodnota u obou skupin je 20 bodů. Minimální hodnota v případě chlapců je 7 bodů a v př́padě dívek 6 bodů. Medián je v př́padě chlapců 15 bodů a v případě dívek 14 bodů. Aritmetický průměr u chlapců připadá na 14 bodů a u dívek také na 14 bodů. Chlapci a dívky tedy v 2. části dotazníku dosáhli stejných výsledků. 


\section{Srovnání jednotlivých tříd}

Graf č. 60 Srovnání počtu bodů žáků 6., 7., 8. a 9. tříd

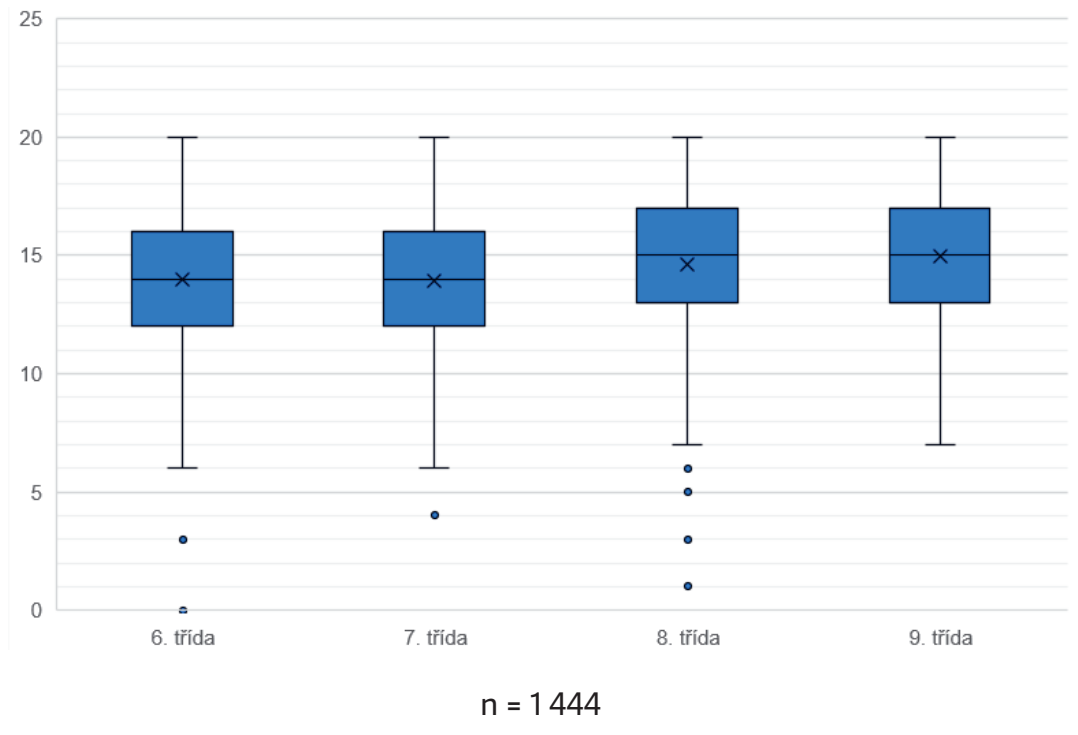

Ve všech třídách byla maximální hodnota počtu bodů 20. Minimální hodnota v případě 6 . a 7. tř́́dy činila 6 bodů a v případě 8 . a 9 . třídy 7 bodů. V 6. tř́dě byl určen medián 14 bodů a aritmetický průměr 14 bodů, stejný výsledek byl zaznamenán i v 7. třídě. Velmi podobná situace nastala i v 8. a 9. třídě, kdy v obou třídách byl zjištěn medián 15 bodů. Aritmetický průměr byl v 8. a 9. třídě také stejný, tedy 15 bodů. $Z$ těchto výsledků plyne velmi zajímavý poznatek - školní vzdělávání v průběhu 2. stupně v podstatě neovlivňuje mediální znalosti žáků. Jedná se tedy o podnět k diskuzi, z jakého důvodu tomu tak je. 


\section{4}

\section{Shrnutí výsledků}

V našem výzkumu jsme se orientovali na žáky 2. stupně ZŠ. Naprostá většina (93,49 \%) z nich jako zdroj informací používá internet. Z hlediska ověřování pravdivosti informací a fotografií nacházejících se na internetu převažuje počet žáků, kteří si informace vždy ověřují (7,76 \%) či většinou ověřují (31,58 \%), nad žáky, kteří si informace nikdy neověřuji (4,01 \%) nebo většinou neověřují (12,88 \%). Odlišné tendence byly zjištěny u ověřování pravdivosti fotografií, kde naopak převažují žáci, kteři si fotografie většinou neověřuji (33,79 \%) a nikdy neověřují (14,13 \%), nad žáky, kteří fotografie většinou ověřují (12,74 \%) a vždy ověřují (4,64 \%). Informace si žáci nejčastěji ověřují z více zdrojů (30,75 \%), u fotografií pak hlavní roli hraje jejich vzhled (zkreslení, známky úpravy ve Photoshopu apod.) - podle tohoto kritéria se rozhoduje $21,47 \%$ žáků.

Žáci nejčastěji uvádějí, že si pravdivost profilů uživatelů na sociálních sítích většinou ověřují (28,53 \%), 11,01 \% žáků pravdivost profilů neověřuje vůbec. Nejčastějším kritériem při rozhodování, zda profil je či není pravdivý, jsou fotografie na profilu (15,10 \%), příspěvky (13,30 \%) a počet sledujících, popř́ípadě přátel (13,23 \%).

Nejvíce žáků (37,81 \%) tvrdí, že pokud jejich oblíbený influencer propaguje určitý výrobek, tak si jej většinou nekoupí. Poměrně malé procento žáků (16,6 \%) uvedlo, že influenceři jsou při propagaci výroků přesvědčeni o jejich kvalitě. Více než třetina žáků (39,9 \%) si myslí, že influenceři o kvalitě propagovaného výrobku přesvědčeni nejsou. Více než polovina žáků (53,67 \%) se pak domnívá, že influenceři určité výrobky propagujíjen kvưli finančnímu zisku. Někteří žáci (12,60 \%) dále uvádějí, že cílem influencerů není jen finanční zisk, ale také potřeba doporučit svým sledujícím určitý výrobek, se kterým mají dobrou osobnízkušenost, přičemžzáležína každém influencerovi,jaké má priority. 
Dále jsme se zaměřili na to, zda žáci napodobují životní styl influencerů (z hlediska stravovacích návyků) a zda žáci drželi někdy dietu nebo dodržovali cvičební režim, aby se podobali svému oblíbenému influencerovi. $Z$ dat plyne, že vždy napodobuje alternativní životní styl influencerů jen velmi nízké procento žáků (0,76 \%) a většinou 3,74 \% žáků. Více než třetina (35,32 \%) žáků životní styl nenapodobuje nikdy. Žáků, kteří někdy dodržovali cvičební režim, aby se podobali svému oblíbenému influencerovi, je 11,22 \%. Relativně malé procento žáků (5,33 \%) někdy drželo dietu a také dodržovalo cvičební režim. Více než polovina žáků (62,05 \%) nikdy nedržela dietu ani nedodržovala cvičební režim.

Více než polovina $(68,28 \%$ ) žáků nikdy nenapsala nenávistný příspěvek na sociální sítě. Téměř pětina (19,95 \%) žáků někdy nějaký nenávistný příspěvek napsala. Tito žáci uvádějí, že se nenávistný příspěvek nejčastěji týkal veřejně známé osobnosti, a to zpěváka, herce, youtubera, influencera apod. Tuto možnost zvolilo 9,56 \% žáků. Četbou nenávistných příspěvků není většinou negativně ovlivněno 28,26 \% žáků. Četba těchto příspěvků většinou negativně ovlivňuje 12,67 \% žáků. Více než čtvrtina žáků (27,01 \%) je těmito př́spěvky někdy negativně ovlivněna a někdy ne.

Žáků, kteří nikdy nebyli obětí nenávistných příspěvků na sociálních sítích, je 78,88 \%. Více než pětina žáků (21,12 \%) byla někdy obětí těchto př́ispěvků. Nejčastěji se příspěvky týkaly vzhledu žáků (7,76 \%), přičemž velmi často byla zmiňována nadváha. Dále příspěvky útočily na osobnost žáků (4,50 \%), a to především na jejich názory, vlastnost a životní styl.

Ve druhé části dotazníku jsme se zaměřili na to, do jaké míry se žáci 2. stupně ZŠ orientují ve vybraných aktuálních problémech mediální výchovy. Použili jsme reálné př́iklady dezinformace, hoaxu, falešných internetových profilů a fotografií, product placementu, sexismu v reklamách, klamavé reklamy, mediálních stereotypů, hatingu a veřejnoprávních médií. Vzhledem k tomu, že byly jednotlivé položky bodovány, mohli žáci získat maximálně 20 bodů. Průměrně žáci získali 14 bodů (z hlediska procent byla průměrná úspěšnost v testu 71,85\%), přičemž dívky získaly průměrně 14 bodů a chlapci také 14 bodů. Chlapci a dívky tedy v 2. části dotazníku dosáhli stejných výsledků. Z hlediska srovnání jednotlivých tříd byl v 6. třídě průměr 14 bodů a stejný výsledek byl zaznamenán i v 7. třídě. Velmi podobná situace nastala i v 8 . a 9. třídě, kdy v 8 . třídě byl pak průměr 15 bodů a v 9 . třídě také 15 bodů.

Žáci byli nejúspěšnější v položkách, které měly některé společné faktory - rozeznání falešných profilů na sociálních sítích a fotografiích, práce s reklamou (a to především odhalení klamavé reklamy a sexismu v reklamách) a následně správná interpretace pojmu fake news. Naopak 
nejvíce chybných odpovědí jsme zaznamenali u položek zabývajících se médii obecně (a to konkrétně mediálními stereotypy, veřejnoprávními médii a komunikačním stylem bulváru) a u položek, které zkoumaly schopnost žáků rozeznat dezinformace či dezinformační weby.

Zajímavá data byla sledována také u položek týkajících se nenávistných projevů na internetu. Více než třetina žáků (36,15 \%) se domnívá, že Facebook nenávistné příspěvky bud' smaže nebo že máme bezmeznou svobodu, a proto nenávistné př́spěvky na internet psát můžeme. Toto zjištění může být impulzem $\mathrm{k}$ zahájení diskuze o hranicích svobody projevu na internetu, která má také přímou souvislost s dalším fenoménem, a to s kyberšikanou.

Veškeré bodové hodnocení v druhé části dotazníku se samozřejmě vztahuje pouze $\mathrm{k}$ obsahu použitého dotazníku. $Z$ výsledků dotazníku nebo jeho částí je však možné vyčíst informace o tom, které z dovedností jsou žáci schopni uplatnit lépe a které hưře, a promítnout pak tyto informace do budoucí výuky. 


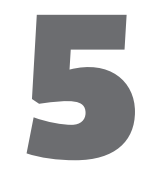

\section{Diskuze}

V této kapitole ve stručnosti popíšeme a shrneme závěry výzkumu Mediální výchova na základních a středních školách ve školním roce 2017/2018, který proběhl pod záštitou České školní inspekce. Výsledky tohoto výzkumu budeme komparovat s výsledky námi realizovaného výzkumu.

Cílem výzkumu Mediální výchova na základních a středních školách ve školním roce 2017/2018 bylo posoudit podmínky a průběh mediální výchovy na 2. stupni ZŠ a SŠ, zhodnotit dosaženou úroveň mediální gramotnosti žáků těchto škol a diskutovat vybrané aspekty rozvoje mediální výchovy. Výzkum se orientoval také na učitele a ředitele jednotlivých škol. Avšak tuto část zmíníme pouze okrajově, protože nás pro potřeby této monografie zajímají zjištění týkající se žáků, a to především žáků na 2. stupni ZŠ.

Do výzkumu bylo zapojeno 4251 žáků 9. tříd ZŠ a 7758 žáků 2. ročníků SŠ. Tito žáci odpovídali na 45 úloh členěných na 75 otázek (vedle toho byla připravena zkrácená verze testu s menším počtem úloh pro žáky se SVP) zaměřených na kritické porozumění textu, rozpoznání mediálního žánru, identifikaci časového vývoje vzniku médií, znalost právního rámce médií apod. Otázky byly tedy zaměřeny na kritickou (21 otázek) i kognitivní složku (54 otázek) mediální gramotnosti. Aktuální problémy mediální výchovy, se kterými v dotazníku pracujeme my, se v testu objevovaly pouze okrajově.

Průměrná úspěšnost žáků 9. ročníku ZŠ v testu činila 43 \% (průměrná úspěšnost žáků 2. ročníku SŠ v testu byla 50 \%), což podle autorů výzkumu naznačuje na nedostatky ve zvládnutí testovaných složek mediální gramotnosti. V našem výzkumu průměrná úspěšnost u žáků 2. stupně ZŠ činila 71,85 \% (konkrétně u žáků 9. ročníků to bylo 74,85 \%). Rozdíly v dosažených výsledcích mezi chlapci a dívkami byly jak u ZŠ, tak u SŠ malé. Ke stejnému zjištění jsme došli i v našem výzkumu. 
Největší problémy žákům působily otázky vyžadující kritické porozumění delšímu mediálnímu textu, kdy žáci na základě tohoto textu rozhodovali o pravdivosti či nepravdivosti souvisejících tvrzení nebo o postoji autora daného sdělení. $V$ našem výzkumu jsme pro podobné účely použili ukázky hoaxů a dezinformací, kdy u položky zobrazující hoax a položky ukazující spojení dezinformace a fotografie byla pozorována vysoká míra úspěšnosti, zatímco u položky zobrazující zprávu na dezinformačním webu a dezinformačním portále byla úspěšnost relativně nízká. Jelikož kritické zhodnocení určitého sdělení činilo více či méně problémy žákům v obou výzkumech, považujeme důraz na rozvoj kritického myšlení napříč všemi předměty za zásadní. Zároveň doufáme, že v budoucnu budou podobné testy mnohem více orientovány právě na kritickou složku mediální gramotnosti se zaměřením na aktuální trendy.

Autoři výzkumu se dále zabývali mediální výchovou z hlediska učitelů na ZŠ a SŠ. Na více než 70 \% škol (z celkového počtu 107 škol) se realizaci mediální výchovy v různé míře věnovala alespoň polovina interních učitelů. Na téměř $90 \%$ těchto škol byla mediální výchova realizována v podobě průřezového tématu $v$ různých předmětech. $Z$ dotazníkového šetření mezi řediteli škol (3 445 ředitelů ZŠ i SŠ) pak vyplynulo, že na 53 školách se mediální výchovou vůbec nezabývají (Česká školní inspekce, 2018, s. 47). 


\section{6}

\section{Závěr}

Oblast mediální výchovy je velmi důležitá a týká se každého žáka základní školy a nejen jí. Vzhledem $\mathrm{k}$ tomu, že problematice aktuálních problémů mediální výchovy nebyla v České republice doposud věnována dostatečná pozornost, přinesly výsledky výzkumu zcela nové informace. Tyto výsledky lze uplatnit nejen na poli vědecké komunity, ale také v každodenní pedagogické praxi. Snažíme se tak otevřít diskuzi o stavu mediální výchovy na základních školách v České republice. V diskuzi klademe důraz především na to, nakolik mediální výchova pracuje s problémy, které jsou v dnešní době aktuální.

Cílem této monografie bylo zjistit, zda jsou žáci 2. stupně ZŠ schopni na základě názorných příkladů rozeznat dezinformace, hoaxy, falešné internetové profily a fotografie, product placement, sexismus v reklamách, klamavou reklamu, mediální stereotypy, hating a veřejnoprávní média. Zaměřovali jsme se také na to, jaký zdroj informací používají žáci nejčastěji, zda si ověřují pravdivost informací, fotografií a profilů uživatelů na sociálních sítích a podle jakých kritérií se rozhodují. Dále nás zajímalo, zda žáky ovlivňují influenceři, které na sociálních sítích sledují, zda píšou nenávistné příspěvky na internet, zda je četba těchto příspěvků negativně ovlivňuje a zda i oni sami byli někdy obětí nenávistných příspěvků na internetu.

Jako výzkumný nástroj jsme použili dotazník, jehož druhou část, která je vlastně takovým kvízem mediální gramotnosti, lze různým způsobem modifikovat (za předpokladu, že budou dodrženy základní znaky jednotlivých položek) a využít ji ve výuce mediální výchovy nebo pro jiné účely. V budoucnu plánujeme tento kvíz rozšírit a doplnit i o další položky související s aktuálními problémy. Zároveň bude vytvořena sada vzdělávacích materiálů, které budou o těchto problémech informovat a které budou použity 
pro edukační účely. Vzdělávacích materiálů na toto téma je v České republice velmi málo, proto jejich tvorbu považujeme v budoucnu za zásadní.

Jedním z přínosů této monografie je také její teoretická část shrnující aktuální problémy mediální výchovy. Většina publikací z oblasti mediální výchovy se věnuje pouze jednomu či dvěma z problémů, avšak žádná z nich neobsahuje jejich komplexní přehled. $Z$ toho důvodu jsme na základě studia odborné literatury a také na základě několikaleté praxe v projektu E-Bezpečí podali ucelený přehled těchto problémů, který může být přínosný nejen pro potřeby edukace.

Věříme, že Vám tato monografie poskytla řadu informací, které budete moci přenášet do své vlastní edukační či jiné praxe.

Klára Mikulcová, Kamil Kopecký autoři 


\section{Seznam použitých zdrojů}

Alvarová, A. (2017). Průmysl lži: propaganda, konspirace a dezinformační válka. Praha: Stanislav Juhaňák - Triton.

Baran, S. J. (2018). Introduction to Mass Communication: Media Literacy and Culture. United States: McGraw-Hill College.

Bartošek, J., Daňková, H. (2010). Žurnalistika a škola: př́ručka pro učitele mediální výchovy. Frýdek-Místek: Václav Daněk.

Bělohlavá, E. (2020). Mediální výchova: učebnice pro 2. stupeň ZŠ a odpovídající ročníky víceletých gymnázií. Plzeň: Fraus.

Bezuchová, K. (2020). Praktický manuál: Jak na označování spoluprací \& právo a influencer marketing. Online: https://www.kvetabezuch.com/ jak-na-oznacovani-spolupraci/

Bína, D. a kol. (2005). Výchova k mediální gramotnosti. České Budějovice: Jihočeská univerzita.

Boese, A. (2019). Hroši žerou trpaslíky. Brno: CPress.

Boyd, D. (2015). It's Complicated: The Social Lives of Networked Teens.

London: Yale University Press.

Boyd, D. M., Ellison, N. B. (2007). Social Network Sites: Definition, History, and Scholarship. Wiley Online Library. Online: https://onlinelibrary. wiley.com/doi/full/10.1111/j.1083-6101.2007.00393.x

Co je klamavá reklama? (2018). Online: https://www.vasenaroky.cz/tipy-arady/co-je-to-klamava-reklama

Černá, A. et al. (2013). Kyberšikana: průvodce novým fenoménem. Praha: Grada.

Česká školní inspekce. (2018). Tematická zpráva-Mediální výchova na ZŠ a SŠ ve školním roce 2017/2018. Online: http://www.csicr.cz/html/2018/ TZ_medialni_vychova_2017_2018/html5/index.html?\&locale=CSY

De Abreu, B. S. (2020). Teaching Media Literacy. Chicago, Illinois: American Library Association.

Dočekal, D. a kol. (2019). Dítě v síti: manuál pro rodiče a učitele, kteří chtějí rozumět digitálnímu světu mladé generace. Praha: Mladá fronta.

Encyklopedický slovník. (1993). Praha: Odeon.

Frélichová, V. et al. (2019). Mimořádné události v globálních souvislostech: metodika pro učitele ZŠ. Praha: Diakonie ČCE - Středisko humanitární a rozvojové spolupráce. 
Gazda, J., Liška, V., Marek, B. (2019). Kritické myšlení: dovednost (nejen) pro 21. století. Praha: Nakladatelství P3K.

Giles, D. (2012). Psychologie médií. Praha: Grada.

Gregor, M., Vejvodová, P. (2018). Nejlepší kniha o fake news, dezinformacích a manipulacích!!! Brno: CPress.

Havlíková, P., Kvasnicová, E. (2020). Sexistická reklama. Brno: Nesehnutí.

Online: http://zenskaprava.cz/files/Sexisticka\%CC\%81-reklama.pdf

Higdon, N. (2020). The Anatomy of Fake News: A Critical News Literacy Education. California: University of California Press.

Housand, B. C. (2018). Fighting Fake News!: Teaching Critical Thinking and Media Literacy in a Digital Age. Buffalo, NY: Prufrock Press.

Hrdina, M., Daňková, H., Kopecká, L. (2015). Projevy nenávisti v online prostoru a na sociálních sítích. Online: https://www.clovekvtisni. cz/media/publications/553/file/1459365027-hate-speechzaverecnazprava-final-verze.pdf

Chráska, M. (2016). Metody pedagogického výzkumu: základy kvantitativního výzkumu. Praha: Grada.

Christian, S. E. (2019). Everyday Media Literacy: An Analog Guide for Your Digital Life. London: Routledge.

Influencer. (2020). Online: https://www.podnikatel.cz/pruvodce/obchodniznacka-brand/influencer-vlivny-uzivatel/

Jechová, K. (2010). Interakce masmédií a dětí staršího školního věku jako východisko pro realizaci mediální výchovy. Online: https://theses.cz/ id/i75zyx/Disertacni_prace_Katerina_Jechova.pdf

Jirák J. a kol. (2013). Média pod lupou: Mediální výchova jako téma celoživotního vzdělávání. Praha: Powerprint.

Jirák, J. (2012). Mediální gramotnost. Revue pro média. Online: http://rpm. fss.muni.cz/Revue/Revue8/rozhovor_jirak_rpmo8.pdf

Jirák, J., Köpplová, B. (2003). Média a společnost: stručný úvod do studia médií a mediální komunikace. Praha: Portál.

Jirák, J., Köpplová, B. (2007). Média a společnost. Praha: Portál.

Kahneman, D. (2012). Myšlení: rychlé a pomalé. Brno: Jan Melvil.

Kopecký, K. (2010). Kybergrooming: nebezpečí kyberprostoru (studie). Online: file:///C:/Users/okay1/Downloads/Prehledovy\%2olist\%2oKybergrooming.pdf Kopecký, K. (2011). Úvod do boje s internetovým trollingem. E-Bezpečí.

Online: https://www.e-bezpeci.cz/index.php/temata/dali-rizika/296uvod-do-trollingu

Kopecký, K., Szotkowski, R. (2019). České děti v kybersvětě (výzkumná zpráva). Online: https://www.e-bezpeci.cz/index.php/ke-stazeni/ vyzkumne-zpravy/117-ceske-deti-v-kybersvete/file 
Kopecký, K., Szotkowski, R. (2019). Dezinformace a fake news (průvodce studiem). Online: https://www.pdf.upol.cz/fileadmin/userdata/PdF/VaV/ 2019/odborne_seminare/Kopecky_Dezinformace_a_Fake_News.pdf Labischová, D. (2011). Didaktika mediální výchovy. Ostrava: Ostravská univerzita v Ostravě.

Lacko, D. (2019). Proč hlupák zůstává hlupákem: a další psychologické fenomény. Brno: Akademické nakladatelství CERM, s.r.o.

Macek, J. a kol. (2019). Být v obraze 2: mediální vzdělávání s využitím audiovizuálních prostředků. Online: https://www.clovekvtisni.cz/ media/publications/1232/file/byt-v-obraze-2.pdf

McLuhan, M. (2011). Jak rozumět médiím: extenze člověka. Praha: Mladá fronta.

McQuail, D. (2009). Úvod do teorie masové komunikace. Praha: Portál. Mičienka, M. a kol. (2007). Základy mediální výchovy. Praha: Portál. Musil, J. (2010). Sociální a mediální komunikace. Praha: Univerzita Jana Amose Komenského Praha.

Neumann, O., Berger, V., Břeštan, R., Engelová, T., Malecký, R., \& Rozehnal, A. (2019). Šok! Hrůza! Média!. Brno: CPress.

Niklesová, E. (2007). Teorie a východiska současné mediální výchovy. České Budějovice: Pedagogická fakulta Jihočeské univerzity v Českých Budějovicích.

Niklesová, E., Bína, D. (2010). Mediální gramotnost a mediální výchova: studijní texty. České Budějovice: Vlastimil Johanus.

Nutil, P. (2018). Média, lži a př́liš rychlý mozek: průvodce postpravdivým světem. Praha: Grada.

Občanský zákoník - § 2977 klamavá reklama. (2014). Online: http://zakony. centrum.cz/obcansky-zakonik-novy/cast-4-hlava-3-dil-2-oddil-2paragraf-2977

Pernisco, N. (2020). Media Literacy: An essential guide to critical thinking skills for our complex digital world. IngramSpark.

Pospíšil, J. (2011). Jak na média. Kralice na Hané: Computer Media.

Pospíšil, J., Závodná, L. S. (2009). Mediální výchova. Kralice na Hané:

Computer Media.

Potter, W. J. (2019). Media Literacy. California: SAGE Publications, Inc. Potter, W. J. (2019). Seven Skills of Media Literacy. California: SAGE Publications, Inc.

Průcha, J., Walterová, E., Mareš, J. (2003). Pedagogický slovník. Praha: Portál. Rámcový vzdělávací program pro základní vzdělávání. (2013). Praha:

MŠMT. Online: http://www.nuv.cz/file/433_1_1

Reifová, I. a kol. (2004). Slovník mediální komunikace. Praha: Portál. 
Rosling, H., Rosling, O., Rosling Rönnlund, A. (2018). Faktomluva: deset důvodů, proč se mýlíme v pohledu na svět - a proč jsou věci lepší, než vypadají. V Brně: Jan Melvil Publishing.

Royal, B. (2016). Principy kritického myšlení. Praha: Ikar.

Sales, N. J. (2017). American Girls: Social Media and the Secret Lives of Teenagers. New York: Vintage.

Sedláková, R. (2014). Výzkum médií: nejuživanější metody a techniky. Praha: Grada.

Scheibe, C., Faith, R. (2011). The Teacher's Guide to Media Literacy: Critical Thinking in a Multimedia World. California: SAGE Publications, Inc.

Schellmann, B. (2004). Média: základní pojmy, návrhy, výroba. Praha: Europa-Sobotáles.

Sloboda, Z. et al. (2011). Mediální tvorba v kontextu vzdělávání: na příkladu česko-německého mediálně-pedagogického projektu o genetice. Brno: Barrister \& Principal.

Smith, J. (2016). Master the Media: How Teaching Media Literacy Can Save Our Plugged-in World. Dave Burgess Consulting, Inc.

Spitzer, M. (2014). Digitální demence: jak připravujeme sami sebe a naše děti o rozum. Brno: Host.

Strculová, V. (2011). Mediální výchova: Praktické náměty pro výuku na 1. stupni ZŠ. Praha: Raabe.

Táborský, J. (2020). V síti (dez)informací: proč věříme alternativním faktům. Praha: Grada Publishing.

Valenta, P., Brom, Z., Kellerová, I. (2016). Mediální činnosti v předškolním a mladším školním věku. Praha: Raabe.

Walker, I. (2013). Výzkumné metody a statistika. Praha: Grada.

Wiesinger, S. (2016). Digital Literacy: A Primer on Media, Identity, and the Evolution of Technology. Switzerland: Peter Lang Publishing Inc. Zbytečný sex v reklamách: Kdo vyhrál Sexistické prasátečko? (2009). Online: https://zpravy.aktualne.cz/ekonomika/zbytecny-sex-vreklamach-kdo-vyhral-sexisticke-pra/r i:gallery:12918/ 


\section{Zdroje obrázků:}

Obrázek 1 Šok v koloniálu (https://www.hatefree.cz/blo/hoaxy/2394romove-maslo)

Obrázek 2 Product Placement (https://www.ceskatelevize.cz/ porady/1126666764-toulava-kamera/)

Obrázek 3 Miloš Zeman (https://www.facebook.com/prezidentcr/, https://www.facebook.com/zeman.milos/)

Obrázek 4 Klamavá reklama (https://www.kupnisila.cz/vanefist-neo/)

Obrázek 5 ZŠ Teplice - nenávistné př́spěvky (https://www.idnes.cz/ usti/zpravy/tablo-prvnaci-teplice-nenavist-hate-free.A171106_100844_ domaci_nub)

Obrázek 6 Dezinformační stránka na Facebooku https://www. evropskehodnoty.cz/wp-content/uploads/2017/02/Anal\%C3\%BDzaobsahu-kampan\%C4\%9B3.pdf)

Obrázek 7 Dezinformační portál (https://www.eurabia.cz/Articles/ 43890-nemecka-vlada-ukradla-respiratory-cr-sr-svycarsku-amadarsku-at-si-vsichni-pochcipaji-hlavne-kdyz-preziji-nemci-jepolitika-berlina.aspx)

Obrázek 8 Sexismus v reklamách (http://zenskaprava.cz/files/sex_cz_ oknaLenini.jpg, https://zpravy.denikplus.cz/1040-sexisticka-pivnireklama-nevkusne-billboardy-pobourily-prahu.html, https://www. lidovky.cz/byznys/foto/NEV37d367_pila_pasakth1.jpg)

Obrázek 9 Zkratka ČTK (https://www.ceskenoviny.cz/zpravy/bmwkvuli-koronaviru-na-ctyri-tydny-zastavi-vyrobu-v-evrope/1868041)

Obrázek 10 Reklama na sociálních sítích (https://www.instagram.com/p/ Be-jYiMFzqH/)

Obrázek 11 Andrej Babiš-Twitter (https://twitter.com/AndreiBabis/ status/1073486514112339968, https://twitter.com/AndrejBabis?ref_ src=twsrc\%5Egoogle\%7Ctwcamp\%5Eserp\%7Ctwgr\%5Eauthor)

Obrázek 12 Kočka Snowball (https://manipulatori.cz/hoax-fotografieobrovske-kocky-snowbal/)

Obrázek 13 Citát (https://wallsdesk.com/albert-einstein-81340/)

Obrázek 14 Dezinformace Cheb (https://www.e-bezpeci.cz/index.php/ priklady/fotografie/1631-uprchlici-na-strese-vlaku-v-chebu) 


\section{O autorech}

\section{Mgr. Klára Mikulcová}

Doktorandka působící na Pedagogické fakultě Univerzity Palackého v Olomouci, která se orientuje na oblast mediální výchovy a mediální gramotnosti. Zabývá se především novými trendy v mediální výchově, jako jsou dezinformace, hoaxy, falešné internetové profily a fotografie, hating, kyberšikana, kybergrooming, internetové výzvy a další.

Od roku 2016 působí jako lektorka prevence rizikové virtuální komunikace $v$ rámci projektu E-Bezpečí. V roce 2020 začala působit jako supervizor vzdělávacích akcí a v současné době je zapojena do činnosti Digidoupěte. V rámci projektu E-Bezpečí se od roku 2014 aktivně podílela na Veletrhu vědy a výzkumu, Dětské univerzitě, Noci vědců, Utuberingu a akcích pod záštitou Seznam se bezpečně. Od roku 2020 také spolupracuje na vzdělávacích materiálech s projektem Jeden svět na školách. Aktivně se zapojuje do množství grantových projektů orientovaných na oblasti rizikového chování ve virtuálním prostředí a rozvoje informační gramotnosti žáků a učitelů.

\section{doc. Mgr. Kamil Kopecký, Ph.D.}

Český vysokoškolský pedagog působící na Univerzitě Palackého v Olomouci, který se orientuje na oblast rizikového chování v prostředí internetu a na moderní IT ve vzdělávání.

Vedoucí projektu E-Bezpečí, vedoucí Centra prevence rizikové virtuální komunikace Pedagogické fakulty Univerzity Palackého v Olomouci, koordinátor projektu E-Bezpečí pro učitele, vedoucí Online poradny E-Bezpečí. Expert bezpečnostního výzkumu, vývoje a inovací Ministerstva vnitra, garant Metodického portálu Výzkumného ústavu pedagogického Praha - modul Bezpečný internet. Od roku 2015 vede nově vzniklou laboratoř IT Centra Prvok, specializovanou na využívání moderních technologií ve vzdělávání. Od roku 2018 je laboratoř známá pod názvem Digidoupě.

Ve své pedagogické činnosti se zabývá mediální výchovou a riziky masmédií, dále komunikačními a informačními systémy, moderními trendy v elektronické komunikaci a rizikovou komunikací ve virtuálním prostředí. Aktivně se zapojuje do množství grantových projektů orientovaných na oblasti rizikového chování ve virtuálních prostředích, krizové intervence, počítačové kriminality a bezpečnostního výzkumu (kyberšikana, kybergro- 
oming, sexting, stalking, kyberstalking, sociální sítě, ochrana osobních údajů). Je autorem řady odborných statí pojednávajících o problematice rizikového chování dětí v prostředí internetu a mobilních telefonů, o krizové intervenci, počítačové kriminalitě a bezpečnostním výzkumu.

Úspěšně propojuje výsledky akademického výzkumu a edukace s komerčními aktivitami, úzce spolupracoval a spolupracuje např. s firmami Google (Webrangers, Grow with Google), Seznam.cz (Seznam se bezpečně!), Vodafone (Digital parenting), Aukro (Rizika online nakupování), v současnosti pak spolupracuje především s firmou O2 (O2 Chytrá škola), NIC.cz (Bezpečně na netu), ČSOB (E-Bezpečí pro seniory), od roku 2020 pak s firmou Avast (Bud' safe online). Od roku 2020 také spolupracuje na vzdělávacích materiálech s projektem Jeden svět na školách. Odborně spolupracoval také na preventivních a dokumentárních filmech Seznam se bezpečně 3 a $\mathrm{Na}$ hory. Aktuálně spolupracuje jako odborný garant na projektu $V$ síti Víta Klusáka. Je také odborným garantem edukační kampaně k tomuto filmu, spolutvůrcem edukativních částí filmu $V$ síti: Za školou (12+) a tvůrcem metodiky pro pedagogy pro práci s tímto filmem.

Další informace o autorovi naleznete na:

www.e-bezpeci.cz, www.prvok.upol.cz. 


\section{Seznam grafů}

Grafč. 1 Věk respondentů 28

Graf č. 2 Výběrový soubor (regionální rozložení) 29

Graf č. 3 Nejpoužívanější zdroj informací 34

Graf č. 4 Ověřování pravdivosti informací a fotografií na internetu 35

Graf č. 5 Ověřování pravdivosti profilů uživatelů na sociálních sítích 40

Graf č. 6 Ochota koupit si výrobek propagovaný oblíbeným influencerem 44

Graf č. 7 Přesvědčení influencerů o kvalitě propagovaného výrobku z pohledu žáků

Graf č. 8 Napodobování alternativního životního stylu (vegetariánství, veganství, raw strava apod.) influencerů $\quad 49$

Graf č. 9 Snaha podobat se oblíbenému influencerovi pomocí držení diet nebo dodržování cvičebního režimu 50

Graf č. 10 Napsali žáci někdy nenávistný příspěvek na sociální sítě? 51

Graf č. 11 Jsou žáci negativně ovlivněni četbou nenávistných príspěvků?

Graf č. 12 Byli žáci někdy obětí nenávistných příspěvků na sociálních sítích?

Graf č. 13 Schopnost rozeznat hoax-jednotlivé odpovědi 58

Graf č. 14 Schopnost rozeznat hoax - správné a chybné odpovědi 58

Graf č. 15 Význam zkratky PP - jednotlivé odpovědi 59

Graf č. 16 Význam zkratky PP - správné a chybné odpovědi 60

Graf č. 17 Význam pojmu "fake news“-jednotlivé odpovědi 61

Graf č. 18 Význam pojmu „fake news“-správné a chybné odpovědi 61

Graf č. 19 Falešný profil na Facebooku -jednotlivé odpovědi 63

Graf č. 20 Falešný profil na Facebooku - správné a chybné odpovědi 63

Graf č. 21 Veřejnoprávní média-jednotlivé odpovědi 64

Graf č. 22 Veřejnoprávní média - správné a chybné odpovědi 64

Graf č. 23 Srovnání variant hodnocení u položky č. 5

Graf č. 24 Klamavá reklama -jednotlivé odpovědi 67

Graf č. 25 Klamavá reklama - správné a chybné odpovědi 67

Graf č. 26 Hating na sociálních sítích - jednotlivé odpovědi 69

Graf č. 27 Hating na sociálních sítích - správné a chybné odpovědi 69 
Graf č. 28 Dezinformační stránka na Facebooku jednotlivé odpovědi

Graf č. 29 Dezinformační stránka na Facebooku správné a chybné odpovědi

Graf č. 30 Srovnání variant hodnocení u položky č. $8 \quad 72$

Graf č. 31 Mediální stereotypy-jednotlivé odpovědi 73

Graf č. 32 Mediální stereotypy - správné a chybné odpovědi 73

Graf č. 33 Zkreslená zpráva na zpravodajském internetovém portálujednotlivé odpovědi $\quad 75$

Graf č. 34 Zkreslená zpráva na zpravodajském internetovém portálu správné a chybné odpovědi $\quad 75$

Graf č. 35 Srovnání variant hodnocení u položky č. 10

Graf č. 36 Sexismus v reklamách - jednotlivé odpovědi $\quad 77$

Graf č. 37 Sexismus v reklamách - správné a chybné odpovědi $\quad 77$

Graf č. 38 Zkratka „ČTK“-jednotlivé odpovědi 79

Graf č. 39 Zkratka „ČTK“ - správné a chybné odpovědi 79

Graf č. 40 Hashtag \#ad-jednotlivé odpovědi 80

Graf č. 41 Hashtag \#ad - správné a chybné odpovědi 81

Graf č. 42 Falešný twitterový účet - jednotlivé odpovědi 83

Graf č. 43 Falešný twitterový účet - správné a chybné odpovědi 83

Graf č. 44 Vědomé šíření nepravdivých zpráv-jednotlivé odpovědi 84

Graf č. 45 Vědomé šíření nepravdivých zpráv - správné a chybné odpovědi $\quad 84$

Graf č. 46 Falešná fotografie -jednotlivé odpovědi 86

Graf č. 47 Falešná fotografie - správné a chybné odpovědi 86

Graf č. 48 Internetový „troll“ - jednotlivé odpovědi 87

Graf č. 49 Internetový „troll“ - správné a chybné odpovědi 87

Graf č. 50 Nesouvisející spojení fotografie a citátu jednotlivé odpovědi $\quad 89$

Graf č. 51 Nesouvisející spojení fotografie a citátu - správné a chybné odpovědi $\quad 89$

Graf č. 52 Komunikační styl bulváru - jednotlivé odpovědi 90

Graf č. 53 Komunikační styl bulváru - správné a chybné odpovědi 90

Graf č. 54 Hoax a upravená fotografie - jednotlivé odpovědi 93

Graf č. 55 Hoax a upravená fotografie - správné a chybné odpovědi 93

Graf č. 56 Odpovědi na všechny položky 94

Graf č. 57 Průměrný počet bodů v obou variantách dotazníku 96

Graf č. 58 Celkové rozdělení bodů 96

Graf č. 59 Srovnání počtu bodů dívek a chlapců $\quad 97$

Graf č. 60 Srovnání počtu bodů žáků 6., 7., 8. a 9. tříd 98 


\section{Seznam tabulek}

Tab. č. 1 Podle jakých kritérií se žáci rozhodují, zda je nějaká informace na internetu pravdivá?

Tab.č. 2 Podle jakých kritérií se žáci rozhodují, zda je nějaká fotografie na internetu pravdivá?

Tab. č. 3 Podle jakých kritérií se žáci rozhodují, zda je profil uživatele na sociálních sítích pravdivý?

Tab.č. 4 Názory žáků na to, proč influenceři propagují výrobky na svých sociálních sítích

Tab.č. 5 Na koho útočily nenávistné příspěvky na sociálních sítích 51

Tab. č. 6 Čeho se týkaly nenávistné příspěvky na sociálních sítích 53 


\section{Seznam obrázků}

Obrázek 1 Šok v koloniálu $\quad 57$

Obrázek 2 Product placement 59

Obrázek 3 Miloš Zeman (Facebook) 62

Obrázek 4 Klamavá reklama 66

Obrázek 5 ZŠ Teplice-nenávistné příspěvky 68

Obrázek 6 Dezinformační stránka na Facebooku 70

$\begin{array}{lll}\text { Obrázek } 7 & \text { Dezinformační portál } & 74\end{array}$

$\begin{array}{lll}\text { Obrázek } 8 & \text { Sexismus v reklamách } & 76\end{array}$

$\begin{array}{lll}\text { Obrázek } 9 & \text { Zkratka ČTK } & 78\end{array}$

Obrázek 10 Reklama na sociálních sítích 80

Obrázek 11 Andrej Babiš (Twitter) 82

Obrázek 12 Kočka Snowball $\quad 85$

Obrázek 13 Citát $\quad 88$

Obrázek 14 Dezinformace Cheb 92 


\section{Anotace}

Monografie prezentuje výsledky výzkumu vybraných aktuálních problémů mediální výchovy u žáků 2. stupně ZŠ a vztah těchto žáků k médiím s důrazem na sociální sítě. Zaměřuje se konkrétně na to, jaký zdroj informací používají žáci nejčastěji; zda si žáci ověřují pravdivost informací, fotografií a profilů uživatelů na sociálních sítích a podle jakých kritérií se rozhodují; zda jsou schopni na základě názorných př́kladů rozeznat dezinformace, hoaxy, falešné internetové profily a fotografie, product placement, sexismus v reklamách, klamavou reklamu, mediální stereotypy, hating a veřejnoprávní média; zda žáky ovlivňují influenceři, které na sociálních sítích sledují; zda žáci píšou nenávistné příspěvky na internet; zda ovlivňuje četba nenávistných příspěvků vztah žáků $\mathrm{k}$ dané skupině (etnické, náboženské apod.) a zda žáci někdy byli obětí nenávistných příspěvků na internetu.

Monografie je rozdělena do pěti kapitol. První kapitola se zabývá teoretickým ukotvením základních pojmů, které s realizovaným výzkumem úzce souvisí. Jedná se o pojmy jako média, mediální výchova, mediální gramotnost a sociální sítě. Ve stručnosti také nastiňuje teoretický základ vybraných aktuálních problémů mediální výchovy, mezi něž řadíme dezinformace, hoaxy, falešné fotografie, falešné účty na sociálních sítích, mediální stereotypy, reklamu a hating.

Jádro monografie tvoří druhá, třetí a čtvrtá kapitola, která shrnuje metodologická východiska a následně výsledky výzkumu. Zde jsou popsány výzkumné cíle a problémy, podoba výzkumného vzorku, zvolená výzkumná metoda, časový harmonogram a způsob zpracování dat. Výsledky výzkumu jsou zde pečlivě zpracovány pomocí tabulek či grafů, analyzovány, okomentovány a shrnuty.

Závěrečná část monografie shrnuje závěry výzkumu Mediální výchova na základních a středních školách ve školním roce 2017/2018, který proběhl pod záštitou České školní inspekce. Výsledky tohoto výzkumu byly komparovány s výsledky námi realizovaného výzkumu. 


\section{Summary}

This monograph presents the findings of a research study that examines the selected current media education problems in lower secondary pupils and their relations to said media, with the emphasis on social networks. Specifically, the research focuses on what source of information pupils use most frequently; whether they verify the veracity of the information, photographs and user profiles on social networks and according to which criteria they decide; whether they are able to recognize, based on real examples, disinformation, hoaxes, false internet profiles and photographs, product placement, sexism in advertisements, surreptitious advertising, media stereotypes, cyberbullying and public service media; whether pupils are affected by influencers they follow on social networks; whether pupils write hateful posts on the internet; whether the reading of hateful affects the pupils' relations to the given group (ethnic, religious, etc.) and whether pupils have ever become victims of hate posts on the internet.

The monograph is divided into five chapters. The first chapter deals with the theoretical definitions of basic concepts that are closely related to the research realized. They include terms such as media, media education, media literacy, and social networks. It also briefly outlines the theoretical foundations of selected current media education problems, which include disinformation, hoaxes, false photographs, false accounts on social networks, media stereotypes, advertising, andcyberbullying.

The core of the monograph is presented in Chapters II, III, and IV, in which the methodological base and its subsequentfindings are summarized. Research objectives and problems, the research sample, selected research method, time schedule, and the data-processing method are described here. The findings are thoroughly processed into tables and graphs, analysed, commented, and summarized.

The concluding part of the monograph summarizes the findings of the research Mediální výchova na základních a středních školách ve školním roce 2017/2018 (Media Education at Primary and Secondary Schools in the School Year 2017/2018), which was conducted under the auspices of the Czech School Inspectorate. The findings of this research were compared with the findings of the research conducted by us. 


\section{Rejstřík}

bulvár 8-9, 16, 19, 30, 90-91, 94-95, 101

ČTK $8,64,38,78-79,94$

dezinformace $5-7,12-16,23,25-26,30$, $35,56,70-71,74-75,92,94-95$, 100-101, 103-104

Facebook 11-12, 16-17, 23, 43-44, 57, $62-63,68-71,92,94-95,101$

fake news 12-13, 35, 61, 90, 94-95, 100 falešná fotografie $5-7,12-13,17-18$, 25-26, 30, 56, 85-86, 94-95, 100, 104 falešný účet/profil $5-7,11-13,16-17$, $25-26,30,39-40,42-43,52,56$, $62-63,82-83,87,94-95,100,104$

hate speech 23

hating $5-7,13,23-26,56,68-69,94-95$, 100,104

hoax 5, 7, 12-13, 15-16, 23, 25-26, 30, 39, 56-58, 92-94, 100, 103-104

influencer $5,11,22,25,27,30,33,42-50$, $99,100,104$

Instagram $11,16-17,23,42-44,55,80-81$ internetový troll 24, 87, 94-95

klamavá reklama 5, 21-22, 25-26, 30, $56,66-67,94-95,100,104$

kybergrooming 17,23

mediální gramotnost 5, 7, 10-12, 25, 97, 102-104

mediální stereotypy $5-7,12-13,19-20$, $22,25-26,30,56,72-73,94-95$, 100-101, 104 mediální výchova 5-7, 9-10, 12-13,15, 25-26, 29, 34-35, 48, 53, 56, 100, 102-105

misinformace 13

nenávistné příspěvky $5,7,12,17,23-27$, $30,33-34,37,50-54,68-69,71,74$, $84,87,95,100-101,104$

podněcování k nenávisti 23,68-69, 71,84

product placement $5,21-22,25-26,30$, $56,59,94,100,104$

propaganda 14-15, 20-21

reklama $6-8,12,16,20-22,25-26,30,44$, $47,56-60,76-77,94-95,100,104$

reklama na sociálních sítích $12,20-22$, $30,44,80-81$

sexismus $5,21-22,25-26,30,56,76-77$, 94-95, 100, 104

sociální sítě $5-7,11-14,16-17,21-23$, 25, 27, 29-30, 33-35, 39-46, 49-53, $69-70,72-73,80,83,95,99,100$, 104

soukromá média 8,61

Twitter 11, 16-17, 82, 94-95

urban legends 13

veřejnoprávní média $5,8,25-26,30$, 56, 64, 94-95, 100-101, 104 
Mikulcová, Klára

Aktuální problémy mediální výchovy a mediální gramotnost žáků 2. stupně

ZŠ / Klára Mikulcová, Kamil Kopecký. -- 1. vydání. -- Olomouc : Univerzita

Palackého v Olomouci, 2020. -- 119 stran

České a anglické resumé

Obsahuje bibliografii a rejstř́k

ISBN 978-80-244-5900-4 (brožováno)

* 37.012 * 373.3 * $316.774: 37.016$ * $316.774: 316.776 .33 / .34$ * 316.774 * $(437.3)$ * $(048.8)$

- pedagogický výzkum -- Česko -- 2020

- základní školy -- Česko

- mediální výchova

- mediální gramotnost

- média

- sociální sítě

- monografie

37 - Výchova a vzdělávání [22]

Klára Mikulcová - Kamil Kopecký

\section{Aktuální problémy mediální výchovy \\ a mediální gramotnost žáků 2. stupně ZŠ}

Odpovědný redaktor Jiří Slavík

Technická redakce Michal Zych

Jazyková korektura Jiří Slavík

Návrh a grafické zpracování obálky Jiří Jurečka

Vydala a vytiskla Univerzita Palackého v Olomouci

Kř́žkovského 8, 77147 Olomouc

www.vydavatelstvi.upol.cz

1. vydání

Olomouc 2020

Neprodejná publikace.

DOI: $10.5507 /$ pdf.20.24459004

ISBN 978-80-244-5900-4 (print)

ISBN 978-80-244-5901-1 (online: PDF)

VUP 2020-0386 (print)

VUP 2020-0387 (online: PDF) 
Monografie prezentuje výsledky výzkumu vybraných aktuálních problémů mediální výchovy u žáků 2. stupně ZŠ a vztah těchto žáků $\mathrm{k}$ médiím s důrazem na sociální sítě. Zaměřuje se konkrétně na to, jaký zdroj informací používají žáci nejčastěji; zda si žáci ověřují pravdivost informací, fotografií a profilů uživatelů na sociálních sítích a podle jakých kritérií se rozhodují; zda jsou schopni na základě názorných př́kladů rozeznat dezinformace, hoaxy, falešné internetové profily a fotografie, product placement, sexismus v reklamách, klamavou reklamu, mediální stereotypy, hating a veřejnoprávní média; zda žáky ovlivňují influenceři, které na sociálních sítích sledují; zda žáci píšou nenávistné př́spěvky na internet; zda ovlivňuje četba nenávistných příspěvků vztah žáků $\mathrm{k}$ dané skupině (etnické, náboženské apod.) a zda žáci někdy byli obětí nenávistných příspěvků na internetu.

Monografie je rozdělena do pěti kapitol. První kapitola se zabývá teoretickým ukotvením základních pojmů, které s realizovaným výzkumem úzce souvisí. Jedná se o pojmy jako média, mediální výchova, mediální gramotnost a sociální sítě. Ve stručnosti také nastiňuje teoretický základ vybraných aktuálních problémů mediální výchovy, mezi něž řadíme dezinformace, hoaxy, falešné fotografie, falešné účty na sociálních sítích, mediální stereotypy, reklamu a hating.

Jádro monografie tvoří druhá, třetí a čtvrtá kapitola, která shrnuje metodologická východiska a následně výsledky výzkumu. Zde jsou popsány výzkumné cíle a problémy, podoba výzkumného vzorku, zvolená výzkumná metoda, časový harmonogram a způsob zpracování dat. Výsledky výzkumu jsou zde pečlivě zpracovány pomocí tabulek či grafư, analyzovány, okomentovány a shrnuty.

Závěrečná část monografie shrnuje závěry výzkumu Mediální výchova na základních a středních školách ve školním roce 2017/2018, který proběhl pod záštitou České školní inspekce. Výsledky tohoto výzkumu byly komparovány s výsledky námi realizovaného výzkumu.

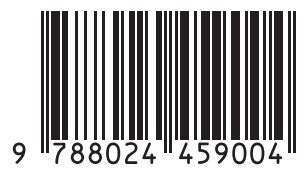

Palacký University

Olomouc 